\title{
Uso de subproductos de la industria agroalimentaria como fuente de fibra. Respuesta de los consumidores.
}

\section{TESIS DOCTORAL}

Presentada por: Ana Curutchet Gonzalez

Dirigida por:

Dra. Amparo Tárrega

Dra. Patricia Arcia Cabrera

Valencia, setiembre 2021 


\section{○UCU}

\section{情 iata}

INSTITUTO DE AGROQUÍMICA Y TECNOLOGÍA DE ALIMENTOS

D. ${ }^{a}$ Amparo Tárrega Guillem, Investigadora del Instituto de Agroquímica y Tecnología de Alimentos del Consejo Superior de Investigaciones Científicas.

Y

D. ${ }^{a}$ Patricia Arcia Cabrera, Docente de alta dedicación UCU.

\section{HACEN CONSTAR:}

El trabajo de investigación "Uso de subproductos de la industria agroalimentaria como fuente de fibra. Respuesta de los consumidores", que presenta D. ${ }^{\text {a }}$ Ana Curutchet Gonzalez para optar al grado de Doctor por la Universidad Politécnica de Valencia ha sido realizado bajo nuestra dirección, reúne las condiciones para ser defendido por su autora.

Valencia, 24 de septiembre 2021

Fdo: Dra. Patricia Arcia Cabrera

Fdo: Dra. Amparo Tárrega Guillem 
Agradecimientos 
En primer lugar, quisiera agradecer al Laboratorio de Propiedades Físicas del Instituto de Agroquímica y Tecnología de Alimentos (IATA-CSIC) de Valencia-España por darme la oportunidad de realizar mi Tesis Doctoral con ellos.

Agradezco muy especialmente a mis tutoras Dra. Patricia Arcia Cabrera y Dra. Amparo Tárrega Guillem por acompañarme, guiarme, motivarme a continuar y apoyarme fuertemente en momentos difíciles.

En España a Isabel Hernando, Laura Laguna y Mónica González por estar siempre disponibles.

En Uruguay a Julieta Trias, Maite Serantes, Fátima Prisco, Carolina Pontet, Juan Menedez, Gabriel Barg, Matías Miguez, Jorge García y Leonardo Salle que colaboraron incondicionalmente.

A mis amigos y compañeros de trabajo, de Uruguay de UCU, LATITUD y LATU que de forma incondicional colaboraron probando tantas muestras, completando largas encuestas aportando todo lo que estaba a su alcance.

Y finalmente, quiero especialmente agradecer a mi familia por el apoyo constante durante todos estos años.

Valencia, Septiembre 2021

Ana Curutchet 
Índice 
RESUMEN..................................................................................................................................... 2

RESUM

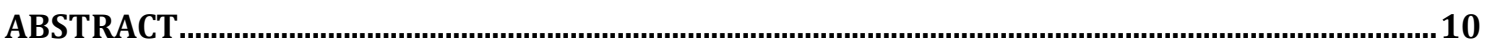

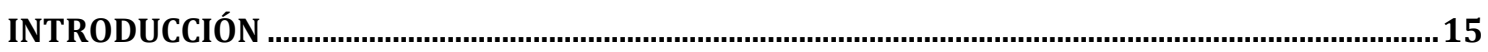

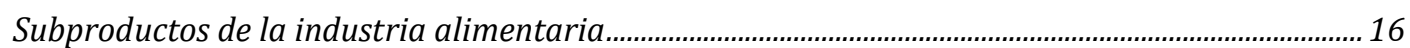

Uso de los subproductos para la mejora del perfil nutricional de alimentos ....................................... 19

La opinión de los consumidores en el desarrollo de nuevos productos..................................................21

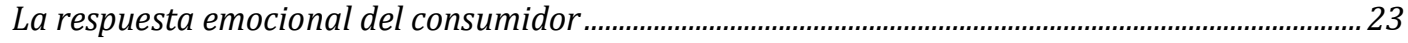

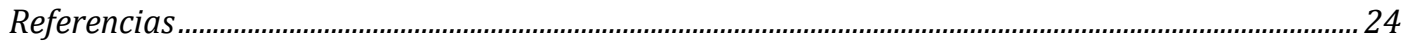

OBJETIVOS

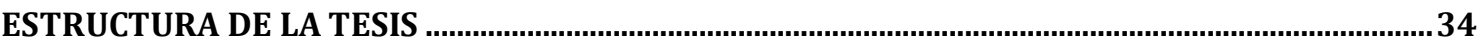

CAPÍTULO 1. INTERÉS DE LOS CONSUMIDORES POR BENEFICIOS NUTRICIONALES...................37

CHANGES IN CONSUMERS INTEREST ON CHEESES WITH HEALTH BENEFITS AND DIFFERENT MANUFACTURE TYPE

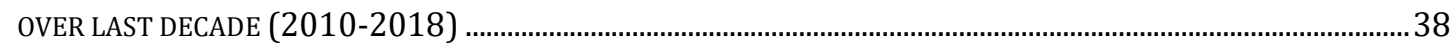

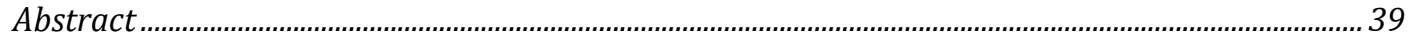

Introduction

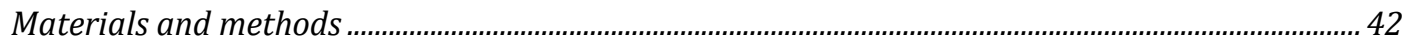

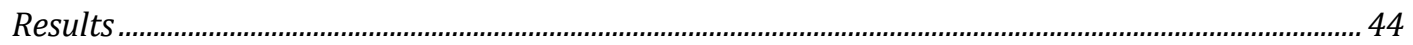

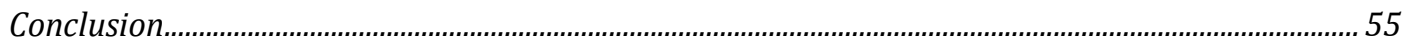

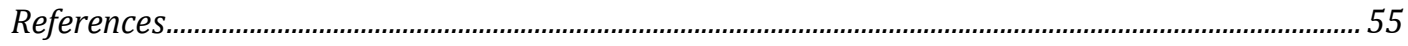

CAPÍTULO 2. USO DEL SUBPRODUCTO DE LA PRODUCCIÓN DE JUGO DE ARÁNDANO COMO

FUENTE DE FIBRA ................................................................................................................................61

BLUEBERRY POMACE AS A SOURCE OF ANTIOXIDANT FIBRE IN COOKIES. CONSUMER'S EXPECTATIONS AND

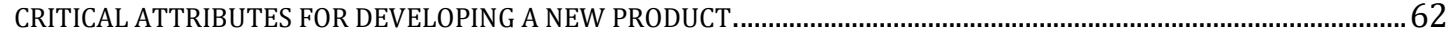

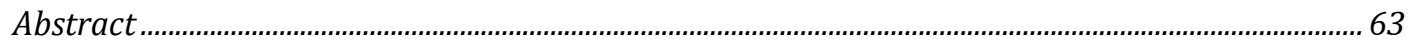

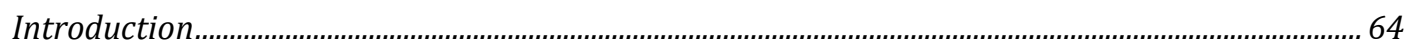

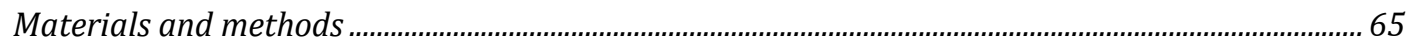

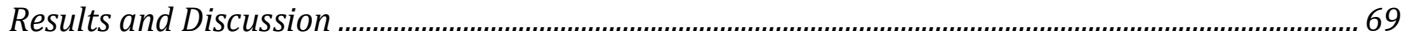

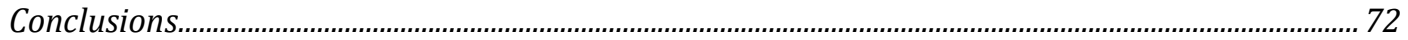

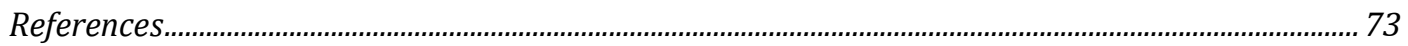

CAPÍTULO 3. USO DEL SUBPRODUCTO DE LA PRODUCCIÓN DE JUGO DE MANZANA COMO

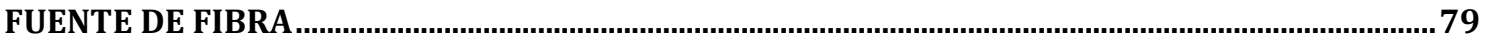

CONSUMERS RESPONSE TO CAKE WITH APPLE POMACE AS A SUSTAINABLE SOURCE OF FIBRE .................................80

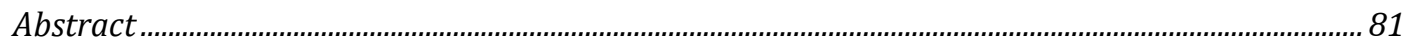

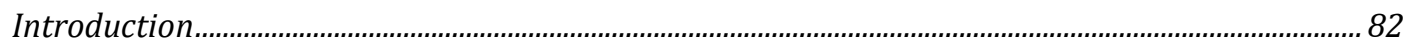

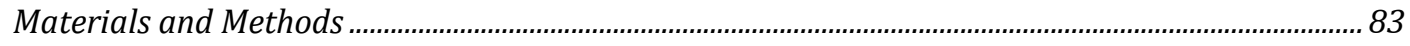

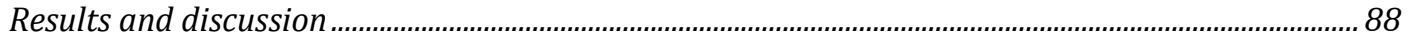

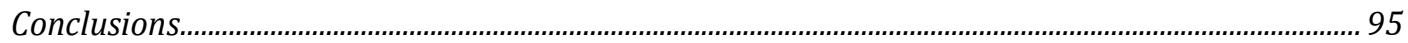

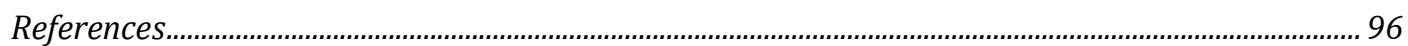

CAPÍTULO 4. USO DEL SUBPRODUCTO DE LA PRODUCCIÓN DE CERVEZA COMO FUENTE DE

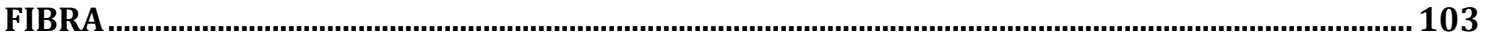

SENSORY FEATURES INTRODUCED BY BREWERY SPENT GRAIN WITH IMPACT ON CONSUMER MOTIVATIONS AND

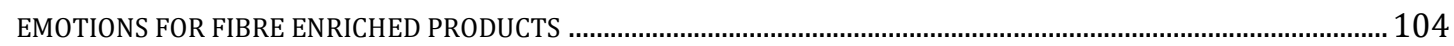

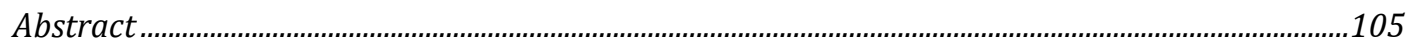

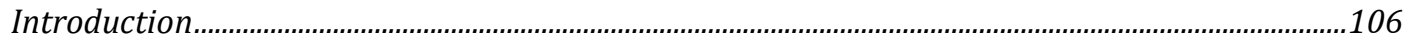

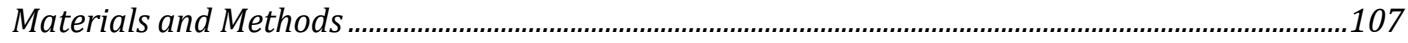

Results and Discussion ..................................................................................................................113

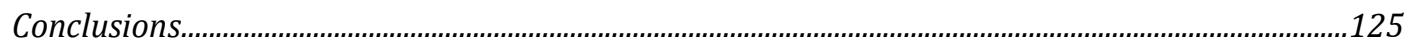

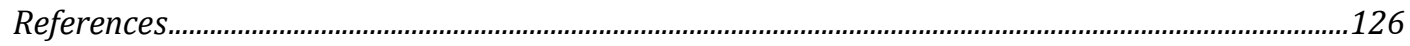


INFLUENCE OF INFORMATION IN CONSUMER RESPONSE TO PACKAGES OF FIBRE ENRICHED BURGERS WITH A BYPRODUCT, BREWERY SPENT GRAIN

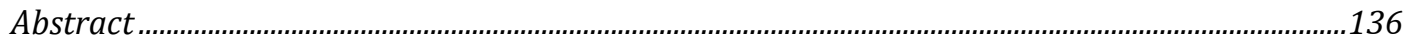

Introduction ..................................................................................................................................................137

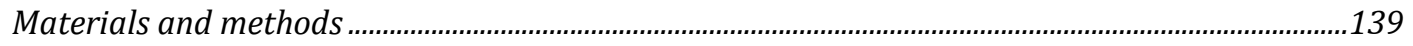

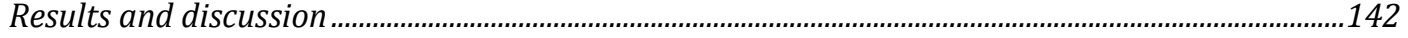

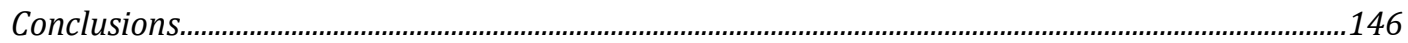

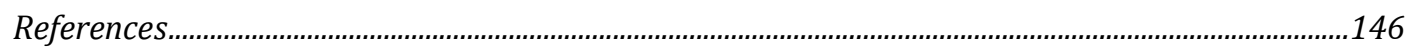

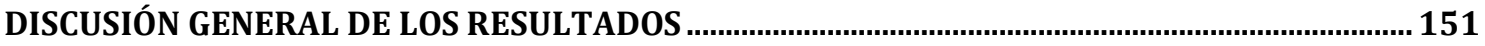

Percepción del consumidor de alimentos con distintos beneficios nutricionales en queso y su evolución en la última década.

Impacto del enriquecimiento en fibra a base de subproductos en la expectativa y la aceptabilidad del consumidor de distintos alimentos ...........................................................................154

Subproducto de producción de jugo de arandanos ..............................................................................154

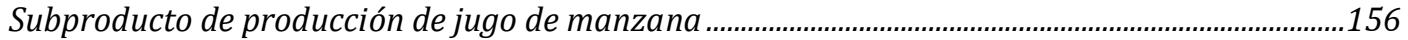

Subproducto de producción de cerveza: Brewery spent grain ............................................................158

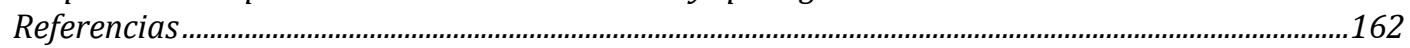

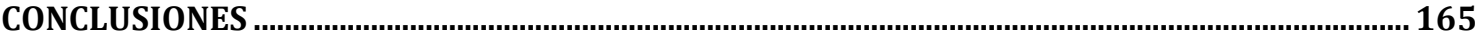





\section{Resumen}


La investigación de la presente Tesis doctoral se centra en estudiar la respuesta del consumidor a productos enriquecidos en fibra mediante la incorporación de subproductos de la industria alimentaria.

En una primera etapa se estudió el interés de los consumidores uruguayos en diferentes mejoras nutricionales (bajo en grasa, reducido en sal, enriquecido en fibra y con probióticos) y el tipo de elaboración (tradicional e industrial) y cómo ha cambiado en los últimos diez años en los que los productos con beneficios se han convertido en habituales del mercado. Los resultados muestran que la respuesta de los consumidores es distinta dependiendo del tipo de queso. En el tipo semi-blando, más tradicional, los consumidores no presentan interés por ninguna de las mejoras nutricionales. En el queso untable, en cambio, hay cierto grado de interés sólo en la reducción de grasa, para la que los consumidores se muestran tan interesados o más que para el queso normal. Respecto a los cambios con el tiempo, se observó para el queso semi-blando, un aumento en el interés por la elaboración artesanal. Contrario a lo esperado no se observó un aumento del interés de los consumidores para ninguna de las mejoras nutricionales, lo que mostró que en el sector de los quesos existe cierta resistencia de los consumidores a cambios en el producto.

En una segunda etapa se estudió el uso de distintos subproductos como ingredientes en el enriquecimiento en fibra de productos de consumo habitual. Se estudió la respuesta de los consumidores a los nuevos productos y a distinto tipo de información en la etiqueta. Como primer subproducto se trabajó con el descarte de la producción de jugo de arándanos. Este se transformó en una harina y se incorporó a la formulación de galletas, reemplazando parte de la harina y parte del azúcar, para desarrollar galletas que se pueden etiquetar como "fuente de fibra". Las expectativas hedónicas de los consumidores al observar la etiqueta de esta galleta fueron tan buenas como una galleta sin fibra. Sin embargo, cuando la probaron sin tener información les gustó menos que la galleta sin fibra, pero al conocer que era rica en fibra aumentó su aceptabilidad ligeramente. Por lo tanto, aunque les interesan las galletas ricas en fibra, no están dispuestos a comprometer aspectos hedónicos por atributos saludables. La harina de arándanos presenta potencial como ingrediente para enriquecer fibra en productos de galletería ya que los consumidores mostraron buenas expectativas, pero las características sensoriales del producto deben de estar alineadas con los atributos intrínsecos esperados. 
El segundo subproducto estudiado fue el generado durante la producción de jugo de manzana. La pulpa que se transformó en harina, se usó para el enriquecimiento en fibra de un bizcochuelo. Se estudió la respuesta de los consumidores al bizcochuelo enriquecido en fibra en presencia o no de la etiqueta con información "fuente de fibra" y "con fibra de manzana", comparativamente con un producto comercial sin fibra. Se evaluó además de la aceptabilidad, las características relevantes para el consumidor en cada uno de los bizcochuelos comparadas con las de su ideal y los motivos por los que lo compraría o no mediante preguntas "Check all that apply "(CATA).

Los resultados indican que la aceptabilidad del bizcochuelo enriquecido en fibra aumentó significativamente con la información, lo que indica que además de la declaración "fuente de fibra", la indicación del origen de la fibra "con fibra de manzana" aumenta la aceptabilidad que el consumidor percibe de estos productos. El bizcochuelo ideal para los consumidores fue descrito como: casero, sabroso, húmedo, suave, esponjoso y saludable. Las características que los consumidores percibieron en el bizcochuelo enriquecido y aumentaron la aceptabilidad fueron casero, saludable y sabroso mientras que las que penalizaron el producto fueron sin sabor y seco que serían las características críticas a mejorar.

Como tercer subproducto se utilizó el residuo de la industria cervecera, BSG por sus siglas en inglés brewery spent grain. Se desarrollaron tres productos diferentes (pan, pasta y leche chocolatada) enriquecidos con fibra mediante la adición de BSG. En primer lugar, se evaluó el impacto del enriquecimiento de la fibra en las características sensoriales, la aceptabilidad y la intención de compra de los consumidores y luego en las emociones que el producto les transmitía. La incorporación de fibra en los tres productos tuvo impacto significativo en las características sensoriales. Sin embargo, estas afectaron de forma distinta a la aceptabilidad y a la intención de compra dependiendo del producto. Para la pasta y el pan donde los cambios eran visibles y reconocidos como presencia de fibra, la intención de compra fue buena y similar al producto sin enriquecer. En lo que respecta a las emociones, se puede percibir una ambivalencia según los diferentes productos enriquecidos dependiendo si la fibra es percibida o no. Cuando la detectan se sienten más confiados en consumir el producto y con menos culpa. Por lo tanto, las características sensoriales que el consumidor percibe asociado a la fibra puede, en algunos productos, 
no sólo aumentar la intención de compra del consumidor sino también hacerle sentir mejor.

Finalmente, se estudió el efecto de la forma de comunicación del enriquecimiento de BSG en la respuesta del consumidor a hamburguesas de carne y si dependía de la marca comercial. Se consideraron tres marcas (una líder, una de bajo precio y una artesanal) y utilizando su empaque original se diseñaron tres etiquetas incluyendo diferente tipo de información: fuente de fibra, fibra de cebada, con fibra natural a partir de un subproducto y un símbolo representando sustentabilidad. La marca fue el único factor estudiado que afectó la intención de compra y sin embargo el tipo de información no tuvo efecto. El análisis de conglomerados mostró dos grupos de consumidores que representan el 30\% de los consumidores con alto interés en la hamburguesa enriquecida en fibra, pero solamente para la marca líder o la artesanal. Cuando los consumidores fueron informados con detalle acerca del origen y las propiedades sustentables y nutricionales del BSG sí que mostraron preferir la alegación "fibra de cebada" en la etiqueta y no les gustó en general incluir el hecho de ser un subproducto. Los resultados parecen indicar que los consumidores quieren incluir BSG en sus productos, quieren saber sobre el origen del ingrediente, pero no quieren conocer a fondo el concepto de subproducto.

Por todo lo obtenido podemos decir que es posible utilizar subproductos de la industria alimentaria como ingredientes para enriquecer nutricionalmente otros alimentos. Para que estos desarrollos sean exitosos se debe tener en cuenta los aspectos sensoriales esperados por el consumidor en el producto a desarrollar y las estrategias de rotulación para informar de la estrategia de enriquecimiento que mejor entienda y valore el consumidor. 
Resum 
La investigació de la present Tesi doctoral se centra en estudiar la resposta del consumidor a productes enriquits en fibra mitjançant la incorporació de subproductes de la indústria alimentària.

En una primera etapa es va estudiar l'interés dels consumidors uruguaians en diferents millores nutricionals (baix en greix, reduït en sal, enriquit en fibra i amb probiòtics) i el tipus d'elaboració (tradicional i industrial) i com ha canviat en els últims deu anys en què els productes amb beneficis s'han convertit en habituals del mercat. Els resultats mostren que la resposta dels consumidors és diferent depenent del tipus de formatge. En el tipus "semi-blando", més tradicional, els consumidors no presenten interés per cap de les millores nutricionals. En el formatge "untable" en canvi hi ha cert grau d'interés només en la reducció de greix, per a la qual els consumidors es mostren tan interessats o més que per al formatge normal. Respecte als canvis amb el temps, es va observar per al formatge semi-bla, un augment en l'interés per l'elaboració artesanal. Contrari a l'esperat no es va observar un augment de l'interés dels consumidors per a cap de les millores nutricionals el que va mostrar que en el sector dels formatges existeix una certa resistència dels consumidors a canvis en el producte.

En una segona etapa es va estudiar l'ús de diferents subproductes com a ingredients en l'enriquiment en fibra de productes de consum habitual. Es va estudiar la resposta dels consumidors als nous productes i a diferent mena d'informació en l'etiqueta. Com a primer subproducte es va treballar amb el descarte de la producció de suc de nabius. Aquest es va transformar en una farina i es va incorporar a la formulació de galetes reemplaçant part de la farina i part del sucre per a desenvolupar galetes que es poden etiquetar com a "font de fibra". Les expectatives de acceptabilitat dels consumidors per a aquesta galeta en observar l'etiqueta van ser tan bones com una galeta sense fibra. No obstant això, quan la van provar sense tindre informació els va agradar menys que la galeta sense fibra, però en conéixer que era rica en fibra va augmentar la seua acceptabilitat lleugerament. Per tant encara que els interessen les galetes riques en fibra, no estan disposats a comprometre aspectes de plaer per atributs saludables. La farina de nabius presenta potencial com a ingredient per a enriquir fibra en productes de galeteria ja que els consumidors van mostrar bones expectatives, però les característiques sensorials del producte han d'estar alineades amb els atributs intrínsecs esperats. 
El segon subproducte estudiat va ser el generat durant la producció de suc de poma. La polpa que es va transformar en farina es va usar per a l'enriquiment en fibra d'una coca. Es va estudiar la resposta dels consumidors a la coca enriquida en fibra en presència o no de la informació de l'etiqueta "font de fibra" i "amb fibra de poma", comparativament amb un producte comercial sense fibra. Es va avaluar a més de l'acceptabilitat, les característiques que segons el consumidor descrivien a cadascuna de les coques comparades amb les de la seua ideal i també els motius pels quals la compraria o no mitjançant preguntes "Check all that apply "(CATA).

Els resultats indiquen que l'acceptabilitat de la coca enriquida en fibra va augmentar significativament amb la informació el que indica que a més de l'al·legació “font de fibra", la indicació de l'origen de la fibra "amb fibra de poma" augmenta l'acceptabilitat que el consumidor percep d'aquests productes. La coca ideal per als consumidors va ser descrita com: casolàna, saborosa, humida, suau, esponjosa i saludable. Les característiques que els consumidors van percebre en la coca enriquida i van augmentar l'acceptabilitat van ser casolana, saludable i saborosa mentre que les que van penalitzar el producte van ser sense sabor i sec que serien les característiques crítiques a millorar.

Com a tercer subproducte es va utilitzar el residu de la indústria cervesera, BSG, per les seues sigles en anglés "Brewery Spent Grain". Es van desenvolupar tres productes diferents (pa, pasta i llet xocolatada) enriquits amb fibra mitjançant l'addició de BSG. En primer lloc, es va avaluar l'impacte de l'enriquiment de la fibra en les característiques sensorials, l'acceptabilitat i la intenció de compra dels consumidors i després en les emocions que el producte transmetia. La incorporació de fibra en els tres productes va tindre impacte significatiu en les característiques sensorials. No obstant això, aquestes van afectar de manera diferent a l'acceptabilitat i a la intenció de compra depenent del producte. Per a la pasta i el pa on els canvis eren visibles i reconeguts com a presència de fibra, la intenció de compra va ser bona i similar al producte sense enriquir. Pel que fa a les emocions, es pot percebre una ambivalència pels diferents productes enriquits depenent si la fibra és percebuda o no. Quan la detecten se senten més confiats a consumir el producte i amb menys culpa. Per tant, les característiques sensorials que el consumidor percep associat a la fibra pot, en alguns productes, no sols augmentar la intenció de compra del consumidor sinó també fer-lo sentir millor. 
Finalment, es va estudiar l'efecte de la forma de comunicació de l'enriquiment de BSG en la resposta del consumidor a hamburgueses de carn i si depenia de la marca comercial. Es van considerar tres marques (una líder, una de baix preu i una artesanal) i utilitzant el seu envàs original es van dissenyar tres etiquetes incloent diferent tipus d'informació: font de fibra, fibra d'ordi, amb fibra natural a partir d'un subproducte i un símbol representant sostenibilitat. La marca va ser l'únic factor estudiat que va afectar la intenció de compra i no obstant això el tipus d'informació no va tindre efecte. L'anàlisi de conglomerats va mostrar dos grups de consumidors que representen el $30 \%$ dels consumidors amb alt interés en l'hamburguesa enriquida en fibra però solament per a la marca líder o l'artesanal. Quan els consumidors van ser informats amb detall sobre l'origen i les propietats sostenibles i nutricionals del BSG si que van mostrar preferir l'al· legació "fibra d'ordi" en l'etiqueta i no els va agradar en general incloure el fet de ser un subproducte. Els resultats semblen indicar que els consumidors volen incloure BSG en els seus productes, volen saber sobre l'origen de l'ingredient, però no volen conéixer a fons el concepte de subproducte.

Per tot l'obtingut podem dir que és possible utilitzar subproductes de la indústria alimentària com a ingredients per a enriquir nutricionalment altres aliments. Perquè aquests desenvolupaments siguen reeixits s'ha de tindre en compte els aspectes sensorials esperats pel consumidor en el producte a desenvolupar i les estratègies de retolació per a informar de l'estratègia d'enriquiment que millor entenga i valore el consumidor. 
Abstract 
The main focus of this work is studying the consumer's response to fibre enriched products by incorporating by-products from the food industry.

In the first stage, the interest of Uruguayan consumers in different nutritional improvements (low-fat, reduced in salt, enriched in fibre and with probiotics) and the method of preparation (traditional and industrial) was studied. In the last decade, products with extra benefits have become much more common in the market, and the variation of this interest in recement years was also studied. The results show that the response of consumers is different depending on the type of cheese. In the more traditional, semi-soft type, consumers are not interested in any of the nutritional enhancements. In spreadable cheese, on the other hand, there is a certain degree of interest only in the reduction of fat, for which consumers are as interested or more than for normal cheese. Regarding the changes over time, an increase in interest in artisanal production was observed for semisoft cheese. Contrary to expectations, there was no increase in consumer interest for any of the nutritional improvements, which showed that in the cheese sector there is some resistance from consumers to changes in the product.

In a second stage, the use of different by-products as ingredients for the fibre enrichment of products of habitual consumption was studied. The response of consumers to new products and to different types of information on the label was studied. The first byproduct used was the residue from the blueberry juice production. This was transformed into a flour and incorporated into the cookie formulation replacing part of the traditional flour and part of the sugar to develop cookies that can be labelled as "source of fibre". The hedonic consumer expectations for this cookie when looking at the label were as good as a non-fibre cookie. However, when they tasted it without information, they liked it less than the non-enriched cookie, although knowing that it was rich in fibre increased its acceptability slightly. Therefore, while consumers are interested in high fibre cookies, they are not willing to compromise hedonic aspects for healthy attributes.

In conclusion, blueberry flour has potential as an ingredient for fibre enrichment in biscuit products, since consumers showed good expectations, but the sensory characteristics of the product must be aligned with the expected intrinsic attributes.

The second by-product studied was the one generated during the production of apple juice. This pulp that was transformed into flour and used for the fibre enrichment of a 
sponge cake. The response of consumers to the fibre enriched sponge cake was studied with and without information on the label ("source of fibre" and "with apple fibre") in comparison with a commercial product without fibre. In addition to acceptability, "Check all that apply" (CATA) question were used to evaluate the characteristics that according to each consumer described each of the biscuits when compared with those of their ideal product.

The results show that the acceptability of the fibre enriched sponge cake increased significantly with the information, indicating that in addition to the claim "source of fibre", knowing the of origin of the fibre "with apple fibre" increases the acceptability that the consumer perceives. The ideal sponge cake for consumers was described as: homemade, tasty, moist, soft, spongy and healthy. The characteristics that consumers perceived in the fibre enriched sponge cake and increased acceptability were homemade, healthy and tasty, while those that penalized the product were tasteless and dry, which would be the critical characteristics to improve.

The third by-product used was the residue from the brewing industry, BSG (brewery spent grain). Three different products were developed (bread, pasta and chocolate milk) enriched with fibre by adding BSG. First, the impact of fibre enrichment on sensory characteristics, acceptability and purchase intention of consumers was evaluated. Finally, the effect of the products on the emotions of the consumers was studied. The incorporation of fibre in the three products had a significant impact on the sensory characteristics. However, these affected acceptability and purchase intention differently depending on the product. For pasta and bread where the changes were visible and recognized as the presence of fibre, the purchase intention was good and similar to the standard product. Regarding emotions, an ambivalence can be perceived in what is generated by the different enriched products depending on whether the fibre is perceived or not. When they detect it, they feel more confident in consuming the product and with less guilt. Therefore, the sensory characteristics that the consumer perceives associated with fibre can, in some products, not only increase the consumer's purchase intention but also make them feel better.

Finally, the effect of the way to communicate the BSG enrichment on the consumer's response to meat burgers, and whether it depended on the commercial brand was studied. Three brands were considered (one leading, one low-priced and one artisanal) and using 
their original packaging, three labels were designed including different types of ways of conveying the information: fibre source, barley fibre, with natural fibre from a byproduct and a symbol representing sustainability. The brand was the only factor studied that affected purchase intention, and the way used to convey the information had no effect. The cluster analysis showed two consumer groups representing $30 \%$ of consumers with a high interest in the fibre enriched hamburger, but only for the leading or artisan brand. When consumers were informed in detail about the origin and the sustainable and nutritional properties of the BSG, they did show a preference for the "barley fibre" claim on the label and generally did not like to include the fact that it is a by-product. The results seem to indicate that consumers want to include BSG in their products, they want to know about the origin of the ingredient, but they do not want to know in depth the concept of by-product.

In conclusion, it is possible to use by-products from the food industry as ingredients to nutritionally enrich other foods. For these developments to be successful, the sensory aspects expected by the consumer in the product to be developed and the labelling strategies must be considered to inform the enrichment strategy that the consumer understands and values best. 


\section{Introducción}




\section{SUBPRODUCTOS DE LA INDUSTRIA ALIMENTARIA}

La generación de residuos es uno de los problemas más relevantes para la industria alimentaria ya que representa el uso ineficiente de los recursos naturales (Caldeira et al., 2019). Constituye a nivel global uno de los mayores retos de nuestra sociedad ya que la cantidad de residuos generados durante el procesado de alimentos es muy importante. De las pérdidas totales de alimentos, un 38\% ocurre durante el procesado de los mismos (Helkar et al., 2016). Los subproductos se eliminan en vertederos, mediante incineración, compostaje o uso en alimentación animal de baja calidad y en general causa problemas ambientales o pérdidas para las industrias, debido al tratamiento de residuos y costos de transporte (Dhillon et al., 2013). Esto unido a un consumidor cada vez más concienciado en el cuidado del medioambiente ha impulsado la búsqueda de alternativas para reducir los residuos industriales convirtiéndolos en coproductos o subproductos (Fărcaş et al., 2017).

La aplicación del concepto de economía circular a subproductos de la industria alimentaria puede conducir a un desarrollo sustentable, mayores beneficios económicos y un uso más eficiente de los recursos mediante la minimización de residuos, así como beneficios medioambientales (Geissdoerfer et al., 2017; Morseletto, P., 2020). La reducción de la pérdida y el desperdicio de alimentos a lo largo de la cadena de suministro, desde la producción hasta el consumo, es esencial para mejorar la disponibilidad de alimentos y, al mismo tiempo, reducir la presión sobre los recursos naturales (Gustavsson et al., 2011).

La definición de valorización es el pos-procesamiento de subproductos incorporados en la producción de otros productos alimenticios. Se han investigado diferentes formas de valorizar los subproductos de la industria de procesado de cítricos, pescado, carne, cereales, raíces y lácteos (Banaszewska et al., 2014). La mayoría de estos estudios se centran en desarrollos biotecnológicos, investigan la posibilidad de extraer nutrientes de subproductos y utilizar partes de estos subproductos en la producción de nuevos productos (Figura 1).

La industria de procesamiento de frutas, verduras, vino y cerveza pueden ser las industrias alimentarias que generan la mayor cantidad de residuos biológicos en el planeta (Comunian et al., 2021). 


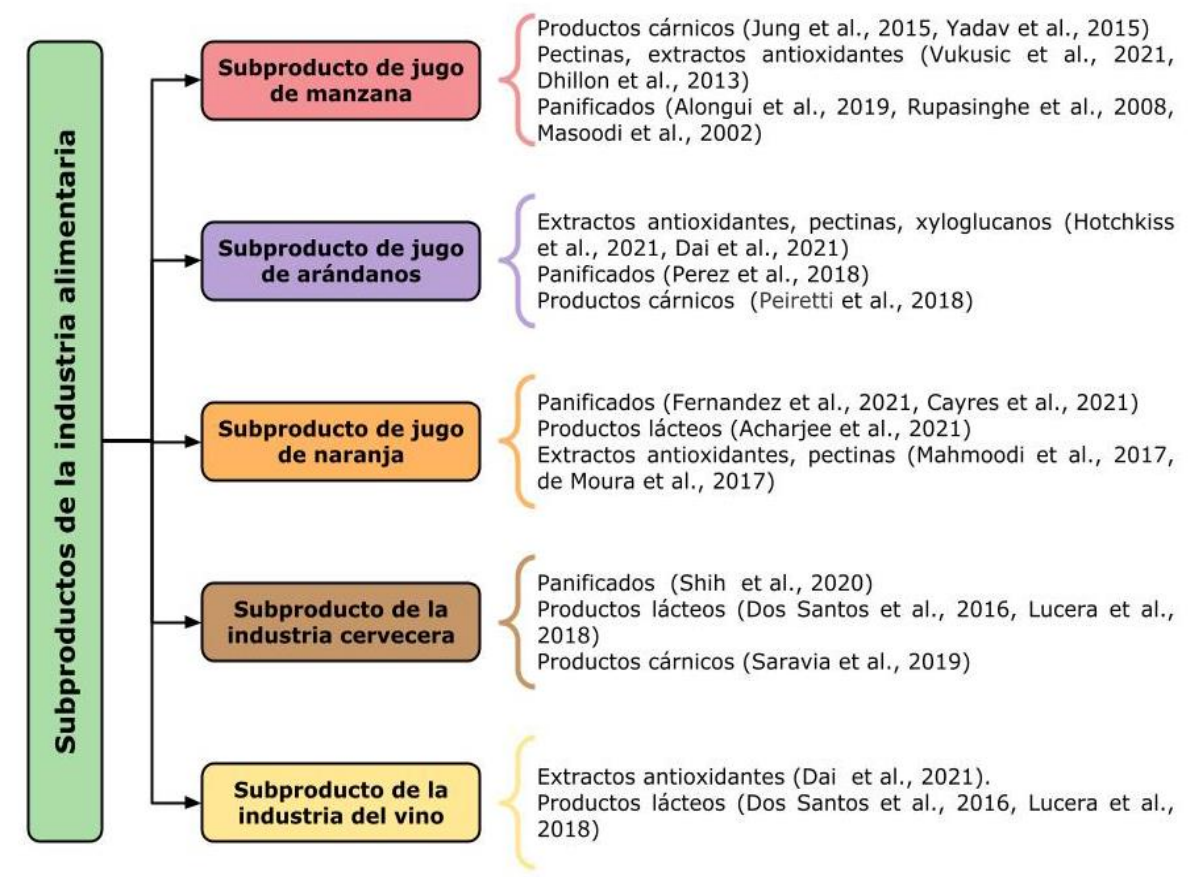

Figura 1: Usos de subproductos de procesamiento de alimentos como ingredientes.

La cerveza es una de las bebidas más consumidas en todo el mundo. En 2019, la producción mundial de cerveza fue de 1,91 mil millones de hectolitros (Conway et al., 2020). Durante el proceso de elaboración de cerveza, los cereales ya malteados se maceran para extraer los azúcares del endospermo de los granos y producir el mosto dulce. Éste es luego hervido con lúpulos y fermentado para dar lugar a la cerveza. Sin embargo, mientras el mosto continúa con este proceso, los remanentes de la cebada malteada se convierten en un residuo. Este residuo es conocido como bagazo de cerveza, comúnmente abreviado por sus siglas en inglés BSG (Brewery Spent Grain), y constituye el subproducto más importante de la industria cervecera, representando el $85 \%$ de los residuos emergentes del proceso productivo (Nigam, P.S. 2017). Basado en la tasa de generación de BSG de aproximadamente $0,2 \mathrm{~kg} / \mathrm{L}$ de cerveza (Fărcaş et al., 2015), se estima que se generan 38,2 millones de toneladas de BSG al año. En cuanto a la composición del BSG, la misma está determinada principalmente por los cereales utilizados y las características del malteado. Es por esto que los valores de composición que se encuentran en la bibliografía varían en un rango amplio: hemicelulosa (20-25\%), celulosa (12-25\%), lignina (12-28\%), proteína (19-30\%), lípidos (10\%) y cenizas $(2-5 \%)$ (Lynch et al., 2016). El alto porcentaje de fibra, superior al $44 \%$ en extracto seco, así como también el elevado porcentaje de proteínas que posee hace que el BSG sea un buen 
candidato como ingrediente funcional en la elaboración de alimentos para el consumo humano (Lynch et al., 2016).

El procesamiento de arándanos en jugo genera desechos que alcanzan el 20\% del peso inicial de la fruta (Šarić et al., 2016). Este desperdicio, o subproducto, generalmente denominado "torta prensada" u "orujo", consiste en semillas, tallos y piel (Bobinaite et al., 2014), y es una fuente rica en compuestos fenólicos que exhiben una importante actividad antioxidante (Šarić et al., 2016). Presenta buenas propiedades nutricionales y funcionales ya que no sólo contiene un $70 \%$ de los polifenoles presentes originalmente en las bayas, sino también grandes cantidades de polisacáridos de la pared celular por lo que puede considerarse también fuente de fibra dietética (Hilz et al., 2005).

Otro residuo de gran volumen a nivel mundial es el de la producción de jugo de manzana. Considerando que a escala mundial se procesan 11 millones de toneladas de manzanas al año y que el descarte resultante del prensado representa aproximadamente un $30 \%$ del peso de la fruta, se generan 3,3 millones de toneladas anuales de residuo, que las industrias deben eliminar o gestionar (USDA, 2018). El residuo de jugo de manzana está hecho de piel y pulpa (95\%), 2\% a 4\% de semillas y 1\% de tallos (Antonic et al., 2020). Este subproducto es una importante fuente de fibra dietética, considerando que cerca de un $40 \%$ de su peso seco es fibra (Alongui et al., 2019). También es rico en polifenoles, flavonoides y antocianinas. Los polifenoles más abundantes en las manzanas son el ácido clorogénico, floridzina y quercetina, y están concentrados principalmente en las semillas y en la cáscara (Antonic et al., 2020). A su vez, es una fuente potencial de antioxidantes, como catequinas, procianidinas y ácido cafeico (Dhillon et al., 2013; H.N. Rabetafika et al., 2014).

Los subproductos de la industria alimentaria ricos en compuestos bioactivos y con un valor nutricional potencial, pueden jugar un rol importante en el desarrollo de nuevos productos saludables (Bedoic et al., 2019) y a su vez contribuir a una producción sustentable. Una de las dificultades que presentan todos estos subproductos es su elevada humedad. Entre el 70 al $80 \%$ de su composición es agua por lo que estos subproductos suelen ser inestables, susceptibles al deterioro microbiológico, la oxidación de polifenoles, degradación de pectinas y pardeamiento enzimático además de suponer elevados costos de transporte. Para estabilizarlos se debe encontrar una solución conjunta a los problemas de gestión de residuos y agotamiento de recursos, mediante el uso eficiente de los residuos como materia prima, promoviendo estrategias basadas en tecnologías verdes y sustentables para lograr su estabilidad (Comunian et al., 2021). 
Una alternativa a esto sería reducir su humedad mediante secado y molerlo hasta obtener una harina (Lima et al. 2019). Esta harina es posible utilizarla como ingrediente para la formulación de otros alimentos o para extraer compuestos bioactivos mediante un procesamiento posterior. Por lo tanto, se logra reducir los costos de transporte y se lo transforma en un producto estable a temperatura ambiente de vida útil extensa. Además, el secado y reducción de tamaño de partícula favorece cualquier procedimiento de extracción que se quiera realizar posteriormente (Lima et al. 2019). De esta forma, hay una reducción en los residuos generados por la industria alimentaria y una optimización de sus insumos, es decir, se utiliza el $100 \%$ de los recursos naturales. Esto tiene un impacto positivo directo sobre la economía y la reducción de la contaminación ambiental. A su vez, su composición nutricional permite mejorar el perfil nutricional de los alimentos en los que se utilicen.

\section{USO DE LOS SUBPRODUCTOS PARA LA MEJORA DEL PERFIL NUTRICIONAL DE ALIMENTOS}

Una alimentación inadecuada está relacionada con una mala elección de alimentos saludables y conduce a una mala salud. Se ha estimado que alrededor de 11 millones de muertes al año en el mundo se pueden atribuir a dietas deficientes (Kaur et al., 2017). Actualmente la población es más consciente de la fuerte relación entre la dieta y la salud, y ha llevado a un cambio en las preferencias alimentarias en las sociedades desarrolladas de forma que los consumidores pueden elegir entre productos aquel que le permita conseguir un estado salud deseable (Bogue et al., 2017).

En lo que respecta a la fibra alimentaria, y su ingesta diaria, Stephen et al., (2017) realizó una revisión sobre el consumo de fibra alimentaria en diez países, incluyendo EE. UU., Reino Unido y España y concluyó que en ninguno de ellos se alcanzaba la cantidad recomendada. La ingesta de fibra alimentaria en los hombres adultos osciló entre 15 y 25 g/día, para las mujeres las cifras fueron de 14 a 21 g/día y para niños de 8 a 12 g/día. Aunque la cantidad varía según la edad y el estilo de vida, debería ser de 30-35 g/día para hombres adultos, 20-25 g/día para mujeres adultas y 10-19 g/día para niños (Stephen et al., 2017). A partir de estos datos, se observa una amplia deficiencia de consumo de fibra alimentaria en países con distintos niveles de desarrollo. El consumo de fibra tiene beneficios potenciales para la salud humana, incluida la prevención de enfermedades crónicas no transmisibles (ENT) como la obesidad, la diabetes y las enfermedades 
cardiovasculares (Nirmala y Joye, 2020). Threapleton et al. (2013) reportan que en relación con la ingesta de fibra alimentaria total, se observa una reducción en el riesgo de padecer enfermedades cardiovasculares entre el 7 y el $9 \%$ por cada incremento de $7 \mathrm{~g} / \mathrm{d}$ ía de fibra consumido. En un informe de la fundación de investigación sobre cáncer WCRF, 2011, el resultado de meta-análisis de quince estudios de cohortes prospectivos evidencia la relación entre el riesgo de padecer cáncer colorectal incidente y la ingesta de fibra. Por cada 10 g/día de fibra consumidos, el riesgo de cáncer colorectal se redujo en un $10 \%$. Un meta-análisis reciente de Kim et al. (2014), basado en siete estudios de cohorte prospectivos para estudiar los factores en la reducción del riesgo de mortalidad, observó un $11 \%$ de reducción en el riesgo de mortalidad con el incremento de 10g/día del consumo de fibra alimentaria.

A partir de esto, resulta relevante la idea de producir harinas a partir de los subproductos de la industria alimentaria y utilizarlos como una estrategia de enriquecimiento en productos pobres desde el punto de vista nutricional.

Para el caso del BSG se ha estudiado su incorporación a diversos productos. Nocente et al., (2019) ha estudiado la incorporación de 5, 10, y 20\% de BSG a pastas secas. Stojceska, (2019) y Arcia et al., (2018) han estudiado la incorporación de hasta en 30\% del subproducto a panificados. Garrett et al. (2021), obtuvieron resultados promisorios para snacks con una inclusión de hasta 40\% de BSG. En todos los casos se logró mejorar el perfil nutricional de los alimentos desarrollados, pero también se afectaron en mayor o menor medida las características sensoriales de los alimentos desarrollados en comparación con los productos originales.

Peiretti et al. (2018) utilizaron el orujo de arándanos para mejorar la estabilidad de hamburguesas de cerdo durante el almacenamiento refrigerado y observaron que la adición de hasta un 3\%, mejoraba la estabilidad de las hamburguesas sin afectar significativamente a las características sensoriales. Perez et al. (2018) incorporaron un $37 \%$ de orujo de arándanos en la formulación de galletas para el desarrollo de productos fuente de fibra y con actividad antioxidante pero que no tuvieron buena aceptabilidad. Šarić et al. (2019) mostraron que en productos sin gluten la incorporación del 30\% de harina de orujo de arándanos afectaba a las propiedades de panificación siendo las masas más duras, que al hornearse perdían más agua resultando en galletas más duras.

El enriquecimiento con la harina obtenida del procesado de jugo de manzana se ha estudiado en tortas, muffins, galletas, panes, snacks extrudidos, hamburguesas y yogures (Alongi et al., 2019; Rupasinghe et al., 2008; Drożdż et al., 2014; Kırbas et al., 2019; 
Jannati et al., 2018; Jung et al., 2015; Wang et al., 2019). Se logra incorporar proporciones adecuadas para mejorar el perfil nutricional de los alimentos, pero esta fortificación modifica las propiedades sensoriales, principalmente el color que afecta negativamente la aceptabilidad en todas las categorías de productos estudiadas menos en el caso de productos cárnicos (Antonic et al., 2020).

Como se puede ver el uso de subproductos de la industria alimentaria como estrategia sustentable para la mejora del perfil nutricional, particularmente del contenido de fibra alimentaria de alimentos es algo promisorio, pero con el desafío de trabajar estrategias para que los consumidores acepten este nuevo concepto de producto. Ya que de antemano se sabe que las propiedades sensoriales de los nuevos desarrollos se verán fuertemente afectadas con la incorporación de los subproductos.

\section{LA OPINIÓN DE LOS CONSUMIDORES EN EL DESARROLLO DE NUEVOS PRODUCTOS}

Los alimentos con beneficios nutricionales son excelentes opciones, ya que pueden mejorar la calidad de vida mediante la prevención de enfermedades relacionadas con la nutrición (Dominguez Diaz et al., 2020). La presencia en el mercado de nuevos alimentos desarrollados mediante la adición de ingredientes funcionales a los alimentos tradicionales proporciona beneficios potenciales para la dieta de los consumidores y nuevas oportunidades comerciales para los productores y la industria. Sin embargo, el éxito en el mercado de un producto que incluye un nuevo ingrediente requiere la aceptación del consumidor y la misma está lejos de ser incondicional. La aceptación está determinada por una multitud de factores tales como la preocupación sobre la salud, la familiaridad de los consumidores con los conceptos y con los ingredientes funcionales, la naturaleza del producto portador, el modo de comunicación del efecto sobre la salud, etc. (Annunziata et al., 2011; Sirò et al., 2008).

Las propiedades intrínsecas del producto, como las propiedades sensoriales, se consideran factores determinantes de la aceptación y la elección de un producto, pero las propiedades extrínsecas, la información en la etiqueta, como la marca, los datos nutricionales y las declaraciones, también pueden desempeñar un papel importante en el comportamiento de compra del consumidor (Ares et al., 2010; Carilllo et al., 2012; Reis et al., 2017). En la Figura 2 podemos ver esquemáticamente todos los factores que influyen en el comportamiento del consumidor. 


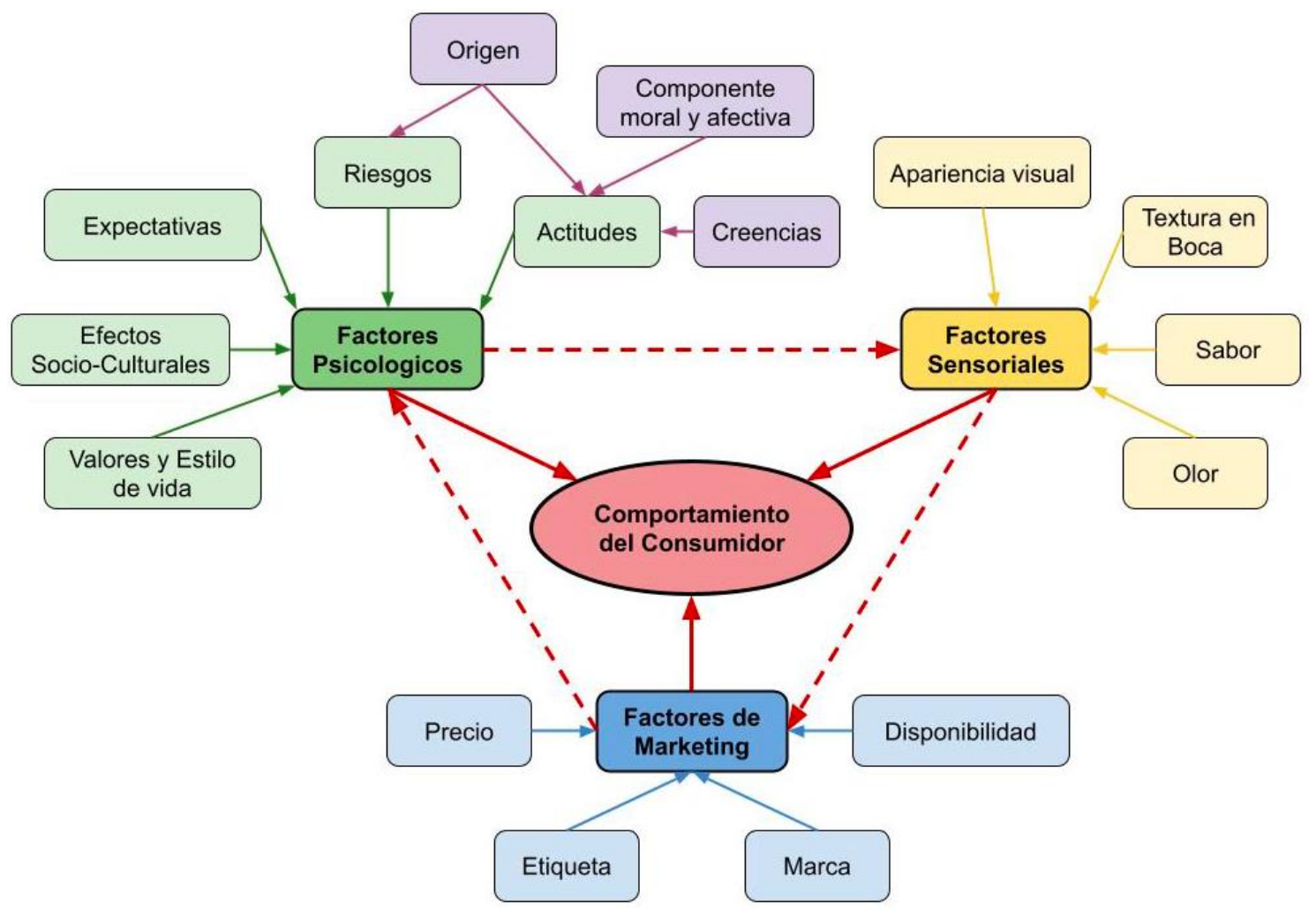

Figura 2: Principales factores que afectan la respuesta del consumidor en alimentos.

Adaptado de Font-i-Furnols et al. (2014).

Muchas investigaciones han demostrado cómo las características relacionadas con la etiqueta pueden influir, positiva o negativamente, en las expectativas del consumidor y en la evaluación hedónica de los productos alimenticios (Grunert et al., 2002; Costell et al., 2010; Ginon et al.; 2009, Gebsky et al., 2019). Existe evidencia que demuestra que los alimentos que contienen declaraciones nutricionales y de propiedades saludables se consideran alternativas más saludables y los consumidores pueden incluso estar dispuestos a pagar un precio superior (Ballco et al., 2020). Pero la respuesta del consumidor no es siempre en el mismo sentido. Cuando los consumidores eligen entre alimentos convencionales y funcionales, sus razones para elegir alimentos funcionales son diferentes dentro de las diferentes categorías de alimentos (Urala y Lähteenmäki, 2004).

En el desarrollo de productos enriquecidos en fibra, es por tanto necesario conocer como se ve afectada la respuesta del consumidor por las nuevas propiedades sensoriales del producto causadas por la incorporación del nuevo ingrediente y por la información proporcionada respecto al beneficio nutricional. En la mayoría de casos, los cambios en 
la formulación de un producto suelen causar una disminución en el grado de aceptabilidad de los consumidores que prefieren las características del producto original (Baixauli et al., 2008). Los productos enriquecidos en fibra frecuentemente son percibidos como de textura áspera, sabor intenso y generadores de sequedad en boca (Mudgil et al., 2017). Pero esto, depende del tipo de producto y la fibra incorporada. Así, el enriquecimiento de salchichas con celulosa microcristalina no tuvo efecto en la aceptabilidad (Ham et al., 2016), mientras que la incorporación de harina integral de arroz en galletas produjo cambios significativos en el color, textura y forma de las galletas obtenidas (Dhillon et al., 2021) y la incorporación de hasta un $40 \%$ de harina integral no afectó a la aceptabilidad. Además, la percepción del consumidor se ve influenciada también por la categoría de producto. Tárrega et al. 2017, encontraron que los consumidores tenían diferentes patrones de preferencia para diferentes fuentes de fibra y que las diferentes respuestas no se asociaban con el conocimiento previo en nutrición si no con el lugar que le daba cada uno a las características sensoriales del producto. Algunos productos son consumidos por placer mientras que otros por su valor nutricional (Maehle et al., 2015). En aquellos productos que sean elegidos por su carácter hedónico los consumidores pueden estar menos dispuestos a aceptar cambios en las características sensoriales.

En ocasiones, cuando los cambios sensoriales permiten al consumidor reconocer en el producto el beneficio, las nuevas características sensoriales se convierten en elementos distintivos para el consumidor que pueden incrementar su aceptabilidad e interés (Baltas, et al., 2001).

El efecto de la información acerca del enriquecimiento en fibra, su contenido o su origen puede también afectar la respuesta del consumidor. Baixauli et al. (2008) estudiaron el efecto de la información sobre fibra en madalenas enriquecidas con diferentes fuentes de fibra alimentaria y encontraron que la aceptabilidad general y de la textura aumentaron cuando se proporcionaba la información nutricional a los consumidores. Ginon et al. (2009) encontraron que los consumidores pagarían más por panes tipo "baguette" etiquetados como fuente de fibra. Especialmente los consumidores jóvenes siempre y cuando sus características sensoriales fueran aceptables.

\section{LA RESPUESTA EMOCIONAL DEL CONSUMIDOR}

En alimentos, la mayor parte de la investigación con consumidores se centra en evaluar el grado de aceptabilidad del consumidor y otros aspectos como la percepción de 
saludable o el grado de confianza/ seguridad que transmite. Pero las emociones son también factores decisivos en nuestra elección de alimentos (Köster et al., 2015; Patel, et al., 2001). Es por ello que, en los últimos años, la evaluación de las respuestas emocionales a los alimentos ha ganado popularidad (King et al., 2013; King et al., 2010) y se ha integrado en la investigación sensorial y del consumidor con el propósito de mejorar la comprensión de las experiencias totales del consumidor y la diferenciación del producto.

Para la medida de la respuesta emocional del consumidor se utilizan respuestas no verbales, que pueden comunicar información muy detallada sobre las experiencias del individuo y ayudan a comprender la aceptabilidad del producto y las diferentes emociones que influyen en la intención de compra (McDuff et al., 2014). Varios factores pueden afectar la respuesta emocional, la edad, la saciedad, la salud, la situación económica y las expectativas. Además de estos, cuando los consumidores se exponen a diferentes productos, pueden provocar dos tipos de respuestas emocionales, conscientes e inconscientes (Berridge et al., 2003; Bettiga et al., 2017).

Una forma de medir la respuesta emocional consciente es por medio de cuestionarios auto reportados como el EsSense Profile ${ }^{\circledR}$ (King et al., 2010). Este cuestionario fue desarrollado para medir las emociones asociadas con alimentos, en un contexto de desarrollo de productos y en un entorno comercial. Se utiliza para describir productos y discriminar entre productos (King et al., 2013).

La intensidad de las emociones aumenta con la frecuencia de uso del producto. Los consumidores que no son usuarios del producto tienen un perfil de emociones diferente, centrado en las emociones negativas, mientras que los que si son usuarios del producto en general tienen emociones positivas más fuertes (King et al., 2010).

El cuestionario EsSense Profile $®$ tiene una excelente relación costo-beneficio, es sencillo de usar e interpretar, cubre una amplia gama de emociones y ha proporcionado información valiosa sobre las percepciones de los consumidores en diversos alimentos como cerveza, bebidas energizantes, el vino y el café. (Chaya et al., 2015; Mehta et al., 2021; Mora et al., 2018; Kanjanakorn et al., 2017).

\section{REFERENCIAS}

Acharjee, A., Afrin, S. M., Sit, N. (2021). Physicochemical, textural, and rheological properties of yoghurt enriched with orange pomace powder. Journal of Food Processing and Preservation, 45 (2). 
Alongui, M., Melchior, S., Anese, M. (2019). Reducing the glycemic index of short dough biscuits by using apple pomace as a functional ingredient. LWT-Food Science and Technology, 100:300-305.

Annunziata, A., Vecchio, R. (2011). Functional foods development in the European market: A consumer perspective. Journal of Functional Food, 3, 223-228.

Antonic, B., Jancikova, S., Dordevic, D., Tremlova, B. (2020). Apple pomace as food fortification ingredient: A systematic review and meta-analysis. Journal of Food Science, 85: 2977-2985.

Arcia, P., Curutchet, A., Cozzano, S., Rodríguez, S. (2018). "Bagazo de cervecería como ingrediente en el desarrollo de panificados. Impacto del rotulado en la intención de compra y aceptabilidad." Revista del Laboratorio Tecnológico del Uruguay, 16, 4046.

Ares, G., Deliza, R. (2010). Studying the Influence of Package Shape and Colour on Consumer Expectations of Milk Desserts Using Word Association and Conjoint Analysis. Food Quality and Preference, 2, 930-937.

Baixauli, R., Salvador, A., Hough, G., Fiszman, S.M. (2008). How information about fibre (traditional and resistant starch) influences consumer acceptance of muffins. Food Quality and Preference, 19, 628-635.

Ballco, P., Caputo, V., de-Magistris, T. (2020). Consumer valuation of European nutritional and health claims: Do taste and attention matter? Food Quality and Preference, 79, 103793.

Baltas G. (2001). The effects of nutrition information on consumer choice. Journal of Advertising Research, 41 (2), 57-63.

Banaszewska, A., Cruijssen, F., Claassen, G.D.H., van der Vorst, J.G.AJ. (2014). Effect and key factors of byproducts valorization: The case of dairy industry. Journal of Dairy Science, 97, 4, 1893-1908.

Bedoic, R., Cosic, B., Duić N. (2019). Technical potential and geographic distribution of agricultural residues, co-products and by-products in the European Union. The Science of the Total Environment, 686, 568-579.

Berridge, K., Winkielman, P. (2003). What is an unconscious emotion? (The case for unconscious "liking "). Cognition and Emotion 17, 181-211.

Bettiga, D., Lamberti, L., Noci, G. (2017). Do mind and body agree? Unconscious versus conscious arousal in product attitude formation. Journal of Business Research, 75, $108-117$.

Bobinaitė R., Pataro, G., Lamanauskas N., Šatkauskas S., Viškelis P., Ferrari G. (2014). Application of pulsed electric field in the production of juice and extraction of 
bioactive compounds from blueberry fruits and their by-products. Journal of Food Science and Technology, 52, 5898-5905.

Bogue, J., O. Collins, O., Troy, A.M. (2017). Market analysis and concept development of functional foods. D. Bagchi, S. Nair (Eds.). Developing new functional food and nutraceutical products, Elsevier Science Publishing Co Inc, Cambridge. 29-45.

Caldeira, C., de Laurentiis, V., Corrado, S., van Holsteijn, S. (2019). Sala Quantification of food waste per product group along the food supply chain in the European union: A mass flow analysis. Resources, Conservation and Recycling, 149, 479-488.

Carrillo, E., Varela, P., Fiszman, S. (2012). Effects of food package information and sensory characteristics on the perception of healthiness and the acceptability of enriched biscuits. Food Research International, 48 (1).

Cayres, C. A., Ascheri, J. L. R., Couto, M. A. P. G. (2021). Evaluation of nutritional characteristics and consumers' acceptance of gluten-free sweet biscuits made from rice-based pregelatinized composite flours containing orange pomace and soy protein isolate. SN Applied Sciences, 3 (2).

Chaya, C., Pacoud, J., Ng, M., Fenton, A., Hort, J. (2015). Measuring the Emotional Response to Beer and the Relative Impact of Sensory and Packaging Cues. Journal of the american society of brewing chemist, 73, 49-60.

Comunian,T.A., Silva, M.P., Souza, C.J.F. (2021). The use of food by-products as a novel for functional foods: Their use as ingredients and for the encapsulation process. Trends in Food Science \& Technology, 108, 269-280.

Conway, J. (2020). Global Beer Production 1998-2019. Alcohol Beverages. Online: https://www.statista.com/statistics/270275/worldwide-beer-production/.

Costell, E., Tárrega, A., Bayarri, S. (2010). Food Acceptance: The Role of Consumer Perception and Attitudes. Chemistry. Perception. 3, 42-50.

Dai, Y., Wu, H., Liu, X., Liu, H., Yin, L., Wang, Z., Xia X., Zhou, J. (2021). Antioxidant activities and inhibitory effects of blueberry pomace and wine pomace crude extracts on oxidation of oil in water emulsion and fish mince. Journal of Food Processing and Preservation, 45 (6).

de Moura, F. A., Macagnan, F. T., dos Santos, L. R., Bizzani, M., de Oliveira Petkowicz, C. L., da Silva, L. P. (2017). Characterization and physicochemical properties of pectins extracted from agroindustrial by-products. Journal of Food Science and Technology, 54(10), 3111-3117.

Dhillon, G.S., Kaur, S., Kaur Brar, S. (2013). Perspective of apple processing wastes as low-cost substrates for bioproduction of high value products: A review. Renewable and Sustainable Energy Reviews, 27:789-805. 
Dhillon, B., Sodhi, N.S., Aneja, E. (2021). Physico-chemical and textural (sensorial and electromyographic) evaluation of cookies formulated using different ratios of brown rice flour and refined wheat flour. Food Measure, 15, 219-227.

Domínguez Díaz, L., Fernández-Ruiz, V., Cámara, M. (2020). An international regulatory review of food health-related claims in functional food products labeling. Journal of Functional Foods, 68, 103896.

Dos Santos, K.M., De Oliveira, I.C. Lopes, M.A., Cruz, A.P.G., Buriti, F.C., Cabral, L.M. (2017). Addition of grape pomace extract to probiotic fermented goat milk: The effect on phenolic content, probiotic viability and sensory acceptability. Journal of the Science ofFood and Agriculture, 97 (4): 1108-1115.

Drożdż, W., Tomaszewska-Ciosk, E., Zdybel, E., Boruczkowska, H., Boruczkowski, T., Regiec, P. (2014). Effect of apple and rosehip pomaces on colour, total phenolics and antioxidant activity f corn extruded snacks. Polish Journal of Chemical Technology, 16, 7- 11.

Fărcaş, A. C., Socaci, S. A., Dulf, F. V., Tofană, M., Mudura, E., Diaconeasa, Z. (2015). Volatile profile, fatty acids composition and total phenolics content of brewers' spent grain by-product with potential use in the development of new functional foods. Journal of Cereal Science, 64, 34-42.

Fărcaş, A. C., Socaci, S.A., Mudura, E., Dulf, F. V., Vodnar, D. C., Tofană, M., Salanță, L. C. (2017). Exploitation of Brewing Industry Wastes to Produce Functional Ingredients. Brewing Technology, Makoto Kanauchi, IntechOpen.

Fernández-Fernández, A. M., Dellacassa, E., Nardin, T., Larcher, R., Gámbaro, A., Medrano-Fernandez, A., Del Castillo, M. D. (2021). In vitro bioaccessibility of bioactive compounds from citrus pomaces and orange pomace biscuits. Molecules, $26(12)$.

Font-i-Furnols, M., Guerrero, L. (2014). Consumer preference, behavior and perception about meat and meat products: An overview. Meat Science, 98, 361-371.

Garrett, R., Bellmer, D., McGlynn, W., Rayas-Duarte, P. (2021). Development of New Chip products from Brewer's Spent Grain. Journal of Food Quality. 5521746, 6.

Gebsky, J., Jesewska-Zychowicz, M., Szlanchciuk, J., Kosicka-Gebska. (2019). M. Impact of nutritional claims on consumer preferences for bread with varied fibre and salt content, Food Quality and Preference, 76, 91-99.

Geissdoerfer, M., Savaget, P., Bocken, N.M.P., Hultink, E.J. (2017). The Circular Economy - a new sustainability paradigm? Journal of Cleaner Production; 143:757-68.

Ginon, E., Lohéac, Y., Martin, C., Combris, P., Issanchou, S. (2009). Effect of fibre information on consumer willingness to pay for French baguettes. Food Quality and Preference, 20(5), 343-352. 
Grunert, K.G. (2002). Current issues in the understanding of consumer food choice. Trends in Food Science and Technology, 13, 275-285.

Gustavsson, J., Cederberg, C., Sonesson, U., Van Otterdijk, R., Meybeck, A. (2011). Global food losses and food waste: extent, Causes and Prevention. Rome: FAO.

Ham, Y.K., Hwang, K.E., Kim, H.W., Song, D.H., Kim, Y.J., Choi, Y.S. and Kim, C.J. (2016). Effects of fat replacement with a mixture of collagen and dietary fibre on small calibre fermented sausages. International Journal of Food Science and Technology, 51: 96-104.

Helkar, P.B., Sahoo, A., Patil, N.J. (2016). Review: Food Industry By-Products used as a Functional Food Ingredients. International Journal of Waste Resources, 6, 1-6.

Hilz, H., Bakx, E.J., Schols, H. A., Voragen, A.G.J. (2005). Cell wall polysaccharides in black currants and blueberries - Characterization in berries, juice, and press cake. Carbohydrate Polymers, 59 (4), 477-488.

Jannati, N., Hojjatoleslamy, M., Hosseini, E., Mozafari, H. R., Siavoshi, M. (2018). Effect of apple pomace powder on rheological properties of dough and sangak bread texture. Carpathian Journal of Food Science \& Technology, 10 (2).

Jung, J., Cavender, G., Zhao, Y. (2015). Impingement drying for preparing dried apple pomace flour and its fortification in bakery and meat products. Journal of Food Science and Technology, 52, 5568-5578.

Kanjanakorn, A., Lee, J. (2017). Examining emotions and comparing the EsSense Profile ${ }^{\circledR}$ and the Coffee Drinking Experience in coffee drinkers in the natural environment. Food Quality and Preference, 56, 69-79.

Kaur, A., Scarborough, P., Rayner, M. A. (2017). Systematic review, and meta-analyses, of the impact of health-related claims on dietary choices. The International Journal Behavioral Nutrition and Physical Activity, 11;14 (1): 93.

Kim, Y., Je, Y. (2014). Dietary fibre intake and total mortality: a meta-analysis of prospective cohort studies. American Journal of Epidemiology, 180, 565-573.

King, S.C., Meiselman, H.L. (2010). Development of a method to measure consumer emotions associated with foods. Food Quality and Preference, 21, 168-177.

King, S.C.; Meiselman, H.L., Carr, T. (2013). Measuring emotions associated with foods: Important elements of questionnaire and test design. Food Quality and Preference, $28,1,8-16$.

Kirbas, Z., Kumcuoglu, S., Tavman, S. (2019). Effects of apple, orange and carrot pomace powders on gluten-free batter rheology and cake properties. Journal of Food Science and Technology, 56, 914-926. 
Köster, E.P., Mojet, J. (2015). From mood to food and from food to mood: A psychological perspective on the measurement of food-related emotions in consumer research. Food Research International, 76, 180-191.

Lima, P.M., Rubio, F.T.V., Silva, M.P., Pinho, L.S., Kasemodel, M.G.C., Favaro-Trindade, C.S. (2019). Nutritional value and modelling of carotenoids extraction from pumpkin (Cucurbita moschata) peel flour by-product International. Journal of Food Engineering, 1-15.

Lucera, A., Costa, C., Marinelli, V., Saccotelli, M., Del Nobile, M., Conte, A. (2018). Fruit and vegetable by-products to fortify spreadable cheese. Antioxidants, 7. 61.

Lynch, K. M., Steffen, E. J., Arendt, E. K. (2016). Brewers' spent grain: a review with an emphasis on food and health. Journal of the Institute of Brewing, 122(4), 553-568.

Maehle, N., Iversen, N., Hem, L., Otnes, C. (2015). Exploring consumer preferences for hedonic and utilitarian food attributes. British Food Journal, 117 (12), 3039-3063.

Mahmoodi, M., Najafpour, G. D., Mohammadi, M. (2017). Production of pectinases for quality apple juice through fermentation of orange pomace. Journal of Food Science and Technology, 54 (12), 4123-4128.

Masoodi, F., Sharma, B., Chauhan, G. (2002). Use of apple pomace as a source of dietary fibre in cakes. Plant Foods for Human Nutrition., 57, 121-128.

McDuff, D., El Kaliouby, R.; Cohn, J.F.; Picard, R.W. (2014). Predicting ad liking and purchase intent: Large-scale analysis of facial responses to ads. IEEE Transaction on Affecting Computer, 6, 223-235.

Mehta, A., Sharma, C., Kanala, M., Thakur, M., Harrison, R., Torrico, D. D. (2021). SelfReported Emotions and Facial Expressions on Consumer Acceptability: A Study Using Energy Drinks. Foods, 10 (2), 330.

Mora, M., Urdaneta, E., Chaya, C. (2018). Emotional response to wine: Sensory properties, age and gender as drivers of consumers' preferences. Food Quality and Preference, $66,19-28$.

Morseletto P. (2020). Targets for a circular economy. Resources Conservation and Recycling; 153:104553.

Mudgil, D., Barak, S., Khatkar, B. S. (2017). Cookie texture, spread ratio and sensory acceptability of cookies as a function of soluble dietary fibre, baking time and different water levels. LWT- Food Science and Technology, 80, 537-542.

Nigam, P.S., (2017). An overview: Recycling of solid barley waste generated as a byproduct in distillery and brewery. Waste Management 62, 255-261.

Nirmala, P., Joye, P.V. Iris J. (2020). Dietary Fibre from Whole Grains and Their Benefits on Metabolic Health. Nutrients, 12, 10: 3045. 
Nocente, F., Taddei, F., Galassi, E., Gazza, L. (2019). Upcycling of brewers' spent grain by production of dry pasta with higher nutritional potential. LWT - Food Science and Technology, 114, 1-6.

Patel, K.A., Schlundt, D.G. (2001). Impact of moods and social context on eating behavior. Appetite, 36, 111-118.

Peiretti, P. G., Gai, F., Zorzi, M., Aigotti, R., Medana, C. (2020). The effect of blueberry pomace on the oxidative stability and cooking properties of pork patties during chilled storage. Journal of Food Processing and Preservation, 44 (7).

Perez, C., Tagliani, C., Arcia, P., Cozzano, S., Curutchet, A. (2018). Blueberry by-product used as an ingredient in the development of functional cookies. Food Science and Technology International, 24(4), 301-308.

Rabetafika, H.N., Bchir, B., Blecker, C., Richel, A. (2014). Fractionation of apple byproducts as source of new ingredients: Current situation and perspectives. Trends in Food Science and Technology. 40 (1):99-114.

Reis, F., Alcaire, F., Deliza, R., Ares, G. (2017). The role of information on consumer sensory, hedonic and wellbeing perception of sugar-reduced products: Case study with orange/pomegranate juice. Food Quality and Preference, 227-236.

Rupasinghe, H. V., Wang, L., Huber, G. M., Pitts, N. L. (2008). Effect of baking on dietary fibre and phenolics of muffins incorporated with apple skin powder. Food Chemistry, 107, 1217- 1224.

Saraiva, B.R., Agustinho, B.C., Vital, A.C.P., Staub, L., Matumoto Pintro, P.T. (2019). Effect of brewing waste (malt bagasse) addition on the physicochemical properties of hamburgers. Journal of Food Processing and Preservation, 43.

Šarić, B., Mišan, A., Mandić, A., Nedeljković, N., Pojić, M., Pestorić M, Đilas, S. (2016). Valorisation of raspberry and blueberry pomace through the formulation of valueadded gluten-free cookies. Journal of Food Science and Technology, 53(2), 11401150 .

Šarić, B., Dapčević-Hadnađev, T., Hadnađev, M., Sakač, M., Mandić, A., Mišan, A., Škrobot, D. (2019). Fibre concentrates from raspberry and blueberry pomace in gluten-free cookie formulation: Effect on dough rheology and cookie baking properties. Journal of Texture Studies, 50 (2), 124-130.

Shih, Y.T., W. Wang, W., Hasenbeck, A., Stone, D., Zhao, Y. (2020). Investigation of physicochemical, nutritional, and sensory qualities of muffins incorporated with dried brewer's spent grain flours as a source of dietary fibre and protein. Journal of Food Science, 85 (11), 3943-3953. 
Siró, I., Kàpolna, E., Kàpolna, B., Lugasi, A. (2008). Functional food. Product development, marketing, and consumer acceptance-A review. Appetite, 51: 456467.

Stephen, A. M., Champ, M. M., Cloran, S. J., Fleith, M., van Lieshout, L., Mejborn, H., Burley, V. J. (2017). Dietary fibre in Europe: current state of knowledge on definitions, sources, recommendations, intakes and relationships to health. Nutrition Research Reviews, 30 (02), 149-190.

Stojceska, V. (2019). Dietary Fibre from Brewer's Spent Grain as a Functional Ingredient in Bread Making Technology. Flour and Breads and their Fortification in Health and Disease Prevention, Preedy, V.R., Watson, R.R., Eds.; Academic Press: Cambridge, MA, USA 16, 171-181.

Tarrega, A., Quiles, A., Morell, P., S. Fiszman, S., Hernando, I. (2017). Importance of consumer perceptions in fibre enriched food products. A case study with sponge cakes. Food \& Function, 8 (2), 574-583,

Threapleton, D.E., Greenwood, D.C., Evans, C.E. (2013). Dietary fibre intake and risk of cardiovascular disease: systematic review and meta-analysis. BMJ, 347, f6879.

Urala, N., Lähteenmäki, L. (2004). Attitudes behind consumers' willingness to use functional foods. Food Quality and Preference, 15, 793-803.

USDA. (2018). Fresh Delicious Fruit: World Markets and Trade (Apples, Grapes \& Pears), Washington DC, USA: Foreign Agricultural Service, 1-30.

Vukušić, J. L., Millenautzki, T., Cieplik, R., Obst, V., Saaid, A. M., Clavijo, L., Zlatanovic S., Hof, J., Mosche, M., Barbe, S. (2021). Reshaping apple juice production into a zero discharge biorefinery process. Waste and Biomass Valorization, 12 (7), 36173627.

Wang, X., Kristo, E., LaPointe, G. (2019). Adding apple pomace as a functional ingredient in stirred-type yogurt and yogurt drinks. Food Hydrocolloids, 100, 105453.

World Cancer Research Fund/American Institute for Cancer Research. (2011). Continuous Update Project Report. Food, Nutrition, Physical Activity, and the Prevention of ColorectalCancer.

http://www.dietandcancerreport.org/cancer_resource_center/downloads/cu/Colore ctal-Cancer-2011-Report.pdf

Yadav, S., Gupta, R. K. (2015). Formulation of noodles using apple pomace and evaluation of its phytochemicals and antioxidant activity. Journal of Pharmacognosy and Phytochemistry, 4(1). 
Objetivos 
El objetivo general de esta tesis fue estudiar la respuesta del consumidor a productos enriquecidos en fibra mediante la incorporación de subproductos de la industria alimentaria. Para ello se plantean los siguientes objetivos específicos:

- Conocer la respuesta de los consumidores uruguayos a diferentes beneficios nutricionales.

- Evaluar el impacto que tiene en la aceptabilidad de los consumidores la incorporación en alimentos de tres subproductos de distinta naturaleza: de la industria cervecera, del procesado del jugo de manzana y del procesado del jugo de arándanos.

- Investigar cómo influye en la expectativa y la aceptabilidad del consumidor la información en la etiqueta de alimentos enriquecidos en fibra a base de subproductos.

- Investigar la respuesta emocional de los consumidores frente a alimentos enriquecidos con fibra a base de subproductos. 


\section{Estructura de la tesis}


Esta tesis se divide en dos partes con las que se busca cubrir los objetivos planteados.

En el capítulo 1 se busca conocer la respuesta de los consumidores a productos con beneficios nutricionales.

Luego, en los siguientes capítulos se estudia el impacto de la incorporación de 3 subproductos de la industria alimentaria a alimentos de consumo masivo.

En el capítulo 2 se estudia el impacto de la incorporación del subproducto de jugo de arándanos a galletas dulces. En el capítulo 3 se estudia el impacto de la incorporación del descarte de jugo de manzana a pre mezclas para bizcochuelos. En el capítulo 4 se estudia el impacto de la incorporación del descarte de la industria cervecera a panes, pasta, leche chocolatada y hamburguesas.

\section{Capítulo 1: Interés de los consumidores por beneficios nutricionales.}

Changes in consumer interest on cheeses with health benefits and different type of manufacture over last decade (2010-2018). Enviado a: Journal of Dairy Science

\section{Capítulo 2: Uso del subproducto de la producción de jugo de arándano como fuente de fibra.}

Blueberry pomace as a source of antioxidant fibre in cookies. Consumer's expectations and critical attributes for developing a new product. Food Science and Technology International, (2019), 25(8): 642-648.

\section{Capítulo 3: Uso del subproducto de la producción de jugo de manzana como fuente de fibra.}

Consumer response to cake with apple pomace as a sustainable source of fibre. Foods, (2021), 10(3), 1-12, 499.

\section{Capítulo 4: Uso del subproducto de la producción de cerveza como fuente de fibra.}

Sensory features introduced by brewery spent grain with impact on consumer motivations and emotions for fibre enriched products. Enviado a: Foods Influence of information in consumer response to packages of fibre enriched burgers with a by-product, brewery spent grain. En preparación. 


\section{CAPÍTULO 1. Interés de los consumidores por beneficios nutricionales}




\title{
Changes in consumers interest on cheeses with health benefits and different manufacture type over last decade (2010-2018)
}

\author{
Ana Curutchet ${ }^{a}$, Patricia Arcia ${ }^{\mathrm{a}, \mathrm{b}}$, Amparo Tárrega $^{\mathrm{c}}$ \\ ${ }^{a}$ Departamento de Ingeniería. Universidad Católica del Uruguay, Comandante Braga 2715 (11600), \\ Montevideo, Uruguay. \\ ${ }^{\mathrm{b}}$ Latitud - Latu Foundation, Av. Italia 6201 (11500), Montevideo, Uruguay. \\ ${ }^{c}$ Physical and Sensory Properties Laboratory. Instituto de Agroquímica y Tecnología de Alimentos, \\ CSIC. Avda. Agustín Escardino, 7 (46980) Paterna (Valencia) Spain
}

Enviado a: Journal of Dairy Science 


\begin{abstract}
This work aimed to study the response of Uruguayan consumers to cheeses with different nutritional and commercial characteristics and determine changes over the last decade. Conjoint analysis was used to establish the value that consumers gave to different health benefits (low-fat, salt-reduced, fibre-enriched, probiotic) and to different manufacturing processes (traditional and industrial) for two different types of cheese (spreadable and semi-soft). Results indicated that consumers' interest varied depending on the proposed health benefit. In general consumers' interest in cheese with specific nutritional benefits was lower than for the regular product. Consumers were interested only in the low-fat cheeses with no change in 2010 and 2018. Manufacture type became significant between years, nowadays consumers are more interested in traditional manufacture. Consumer segmentation showed that some groups were willing to consume cheeses with health benefits and, among the different options, since 2018 are new opportunities for functional cheeses.
\end{abstract}

Keywords: cheese, healthy diet, conjoint analysis, consumers, time-lapse, manufacture type 


\section{INTRODUCTION}

A poor diet is related to poor healthy food choices and leads to ill health. It has been estimated that about 11 million deaths a year worldwide are attributable to deficient diets (Kaur, Scarborough, \& Rayner, 2017). That is the reason for an increasing awareness about the strong relation between diet and human health, this has changed food preferences in developed societies that leads consumers to choose a concrete food product over another with the view to obtaining some desirable health end-state (Bogue et al., 2017). In this sense, functional products are excellent food options as they are aimed to improve life quality by preventing nutrition-related diseases (Dominguez Diaz et al., 2020).

The launch on market of new foods developed by adding functional ingredients to carrier foods provides potential benefits for consumers' diets and new business opportunities for producers. As a consequence, new functional food products are continuously introduced and competition has considerably increased (Annunziata et al. 2011). Many studies have focused on consumer awareness and acceptance of functional foods. A common result of these studies is that consumer acceptance of functional foods is far from being unconditional. Acceptance is determined by a multitude of factors such as primary health concerns, consumers' familiarity with the concepts and with the functional ingredients, the nature of the carrier product, the communication mode of health effect, etc. (Annunziata et al., 2011; Sirò et al., 2008). Evidence from previous studies has shown that food products bearing nutritional claims and health claims are seen as healthier alternatives and consumers are willing to pay a premium (Ballco et al., 2020).

The functional food market is dominated by carotenoids, dietary fibres, fatty acids, minerals, vitamins, prebiotics, probiotics and synbiotics (Turkmen et al., 2019). Dairy products are considered by consumers as one of the most credible product carriers to host functional ingredients, and consumers' acceptance and preferences towards nutritionmodified and functional dairy have been largely investigated in literature (Awaisheh, 2011; Rodrigues, et al. 2011; Gutierrez \& Barreto, 2010; Fritzen-Freire, et al., 2010, Ares \& Gambaro. 2007). In Uruguay, as in the rest of the world, dairy is the sector that has expanded most with the introduction of functional products (Bimbo et al., 2017). Ares et al., (2008) showed that Uruguayan consumers were in general willing to consume food products with a positive impact on their health, particularly those that could reduce the risk of cardiovascular diseases or cancer or boost their immune system. Bimbo et al., 
(2017) show a general consensus among the literature reviewed that the brand increases the acceptance and motivates consumers' choice of nutrition-modified and functional dairy products over conventional ones. Such influence is particularly strong among consumers who are less likely to engage in a healthy lifestyle, while they have poor effect on the choices of consumers with high interest in health.

In the line of dairy products, cheese is widely consumed, and it is also an interesting alternative to develop healthy products. So, it should be important to identify which health benefits of cheese interest consumers most. Also, it may be considered that consumers could be concerned with the type of cheese manufacturing process employed. In many countries, cheeses are produced by both big dairy industries and small producers, which consumers relate with industrial and traditional manufacture, respectively. For some consumers, traditionally manufactured products are linked to cultural heritage and to the sustainability of rural areas (Van Loo et al., 2019). Soares et al., (2017) report that "Manufacturing method" was one of the main responsible for differentiating Brazilian consumers' perceptions in coalho cheese.

Recent years have witnessed a strong increase in the number of products offered in the market, incorporating new ingredients such as fibre, prebiotics, probiotics, etc., or those with reduced content of certain components like fat, sodium or sugar or others indicating its origin or type of manufacturing method. But, depending on consumers 'origin, they may be predisposed differently to consume those kinds of foods, explained by their cultural differences, habits and customs, (van Trijp \& van der Lans, 2007). These could explain that time can also influence consumer response, some places could need more time or not to accept "new products". In this way Ngapo et al., 2006, reported that fatness of beef cuts has been an important characteristic in consumer preferences at purchase for the last 50 years, but the level of fat preferred by the consumer has not remained static, the majority of today's British consumers preferring leaner meat than their predecessors. To determine which characteristics of a product are most interesting or attractive to a consumer, conjoint analysis results in a useful technique, often used in market research (Moskowitz \& Silcher, 2006). It can be applied to determine which functional benefits of nutritional claims consumers may consider more attractive or reliable (Moskowitz, Beckley, \& Minkus-McKenna, 2004, Drewnowski, Aggarwal, Hurvitz, Hastert, \& Moudon, 2010). 
With respect to the presence of cheeses with functional characteristics in the Uruguayan market, in 2010 there was cheeses low fat mainly, followed by salt-reduced. In 2018, in addition to low-fat and salt-reduced, there was cheese with probiotics as the most recent. The aim of this work was to determine the value that Uruguayan consumers give to different health benefits and commercial characteristics on spreadable and semi-soft cheese and to evaluate if this response changes over a short period of time.

\section{MATERIALS AND METHODS}

\section{Conjoint design}

The study was carried out for two types of cheese widely consumed in Uruguay: a spreadable cheese and a semi-soft cheese (Danbo cheese) in two different periods of time. It was done first in 2010 and it was repeated in 2018.

For each type of cheese two factors were considered: different health benefits and different types of manufacturing process. The first factor comprised five levels: four different health benefits (low-fat, salt-reduced, fibre enriched and probiotic) and a regular product. In the second factor, the traditional and industrial type of manufacture were considered. The two factors varied independently following a full factorial design of $5 \times 2$. So, ten vignettes with the description of the product combining both factors were created for each type of cheese.

\section{Surveys}

An online survey was shared among Uruguayan consumers (application Google DocsHome of Google). In the survey, each one of the ten vignettes generated was presented monadically following a Williams Latin square design, the respondent had to indicate the degree of interest in each hypothetical product by using a 9-point scale, from "I'm not interested at all" to "I'm very interested". After that, participants completed the General Health Interest questionnaire proposed by Roininen, Lähteenmäki and Tuorila (1999) using the Spanish version reported by Villegas, Carbonell and Costell (2008) (Table 1). Finally, respondents completed some demographic questions. Participants did not receive monetary compensation.

In the survey done in 2010 one hundred and sixty-two people completed the survey. $61 \%$ were women and $39 \%$ were men. The $67 \%$ of participants were from 18 to 40 years old and the $33 \%$ from 40 to 66 years old. 
In the survey done in 2018 one hundred and fifty-six people completed the survey. $62 \%$ were women and $38 \%$ were men. The $53 \%$ of participants were from 18 to 40 years old and the $47 \%$ from 40 to 66 years old.

Table 1. General health interests multiple scale. Extracted from Roininen et al. (1999)

\begin{tabular}{|c|c|}
\hline & Items \\
\hline 1. $\mathrm{R}^{1}$ & The healthiness of food has little impact on my food choices. \\
\hline 2. & I am very particular about the healthiness of food I eat. \\
\hline 3. $\mathrm{R}$ & I eat what I like and I do not worry much about the healthiness of food. \\
\hline 4. & It is important for me that my diet is low in fat. \\
\hline 5. & I always follow a healthy and balanced diet. \\
\hline 6. & $\begin{array}{l}\text { It is important for me that my daily diet contains a lot of vitamins and } \\
\text { minerals. }\end{array}$ \\
\hline 7. $\mathrm{R}$ & The healthiness of snacks makes no difference to me. \\
\hline 8. $\mathrm{R}$ & I do not avoid foods, even if they may raise my cholesterol. \\
\hline
\end{tabular}

${ }^{1}$ Negative statements (marked with an "R" after the statement number) are recoded for the final score.

\section{Data analysis}

To study the variability in consumers' interest in the cheeses described in the vignettes, a mixed ANOVA of three factors, two fixed (health benefit and type of processing) with interaction and one random (consumer) was applied. When the effects were significant, differences were calculated using Tukey's test $(\alpha=0.05)$.

The utility value for each factor level, for the total consumer panel, was obtained from the ANOVA regression model.

For each consumer an ANOVA model was applied to determine the individual regression, data were accepted if $R^{2} \geq 0.66$. To identify groups of consumers, hierarchical cluster analysis considering Euclidean distances and with Ward's aggregation method were applied.

The utility value for each factor level, for each consumer group, was obtained from the ANOVA regression model.

Composition of each cluster according to consumer gender, age and interest in a healthy diet were compared using the Chi-square test. Significant differences among proportions were determined using Marascuilo procedure (Levy, 1975). 
For each characteristic, differences in the utility values obtained in 2010 and 2018 were determined by t-student test $(\alpha=0.05)$ were applied. Data analyses were performed using the software XLSTAT 2020.3.1 Version (Addinsoft, France).

\section{RESULTS}

\section{Consumers' interest in spreadable cheese with different benefits and type of manufacture}

\section{Survey conducted in 2010}

ANOVA results (Table 2) of the total dataset showed that in general the interest of consumers in spreadable cheese varied significantly depending on the health benefit. The manufacture type and the interaction effects were not significant indicating that their interest in the nutritional benefit on spreadable cheeses did not depend on the manufacture type. Utility values (Table 3) showed that in general consumers were interested in lowfat products as well as the regular one.

Table 2. Influence of information about health benefit and manufacture type on consumer interest on spreadable and Danbo cheeses in 2010 and 2018. Results of Analysis of Variance. $F(4,1,4)$ ratio and probability $(p)$ values.

\begin{tabular}{|c|c|c|c|c|c|}
\hline \multirow[b]{2}{*}{ Type of cheese } & \multirow[b]{2}{*}{ Factor } & \multicolumn{2}{|c|}{2010 Survey } & \multicolumn{2}{|c|}{2018 Survey } \\
\hline & & $\mathrm{F}$ & $\mathrm{p}$ & $\mathrm{F}$ & $\mathrm{p}$ \\
\hline \multirow{3}{*}{ Spreadable } & Health benefit & 21.7 & 0.000 & 28.7 & 0.000 \\
\hline & Manufacture type & 2.5 & 0.111 & 3.5 & 0.063 \\
\hline & $\begin{array}{l}\text { Health benefit x } \\
\text { Manufacture type }\end{array}$ & 0.4 & 0.820 & 0.5 & 0.744 \\
\hline \multirow{3}{*}{ Danbo } & Health benefit & 59.8 & 0.000 & 47.5 & 0.000 \\
\hline & Manufacture type & 0.5 & 0.460 & 9.2 & 0.003 \\
\hline & $\begin{array}{l}\text { Health benefit } \mathrm{x} \\
\text { Manufacture type }\end{array}$ & 0.7 & 0.617 & 1.0 & 0.385 \\
\hline
\end{tabular}

To identify possible different patterns in consumers' interest for the different cheeses, cluster analysis was applied. ANOVA showed that the effect of health benefit and 
manufacture type was significant in all the three clusters (Table 4). However, the size and sense of these effects were different depending on the cluster as it is shown by the utility values (Figure 1, a).

Table 3. Values of the parameters of the utility model for spreadable cheeses in relation with health benefits and processing type.

\begin{tabular}{|c|c|c|c|}
\hline \multirow[t]{2}{*}{ Factor } & \multirow[t]{2}{*}{ Level } & \multicolumn{2}{|c|}{ Utility values } \\
\hline & & 2010 & 2018 \\
\hline \multirow{5}{*}{ Health benefit } & Low-fat & $0.61^{\mathrm{a}}$ & $0.56^{\mathrm{a}}$ \\
\hline & Fibre-enriched & $-0.43^{b, c}$ & $-0.44^{b}$ \\
\hline & With Bifidus & $-0.33^{b}$ & $-0.41^{b}$ \\
\hline & Salt-reduced & $-0.50^{\mathrm{c}}$ & $-0.42^{b}$ \\
\hline & None (regular) & $0.66^{\mathrm{a}}$ & $0.70^{\mathrm{a}}$ \\
\hline \multirow{2}{*}{ Process } & Industrial & 0.07 & -0.09 \\
\hline & Traditional & -0.07 & 0.09 \\
\hline
\end{tabular}

Value of the constant in the model was 5.17 and 5.49 for spreadable cheese in 2010 and 2018 respectively. a-b Within each column and for each factor, mean values followed by different letters are significantly different $(\mathrm{p} \leq 0.05)$.

Parameters with * correspond to those with significant difference between years according to t-student test.

Table 4. Influence of information about health benefit and manufacture type on consumer interest on spreadable cheeses in 2010. Results of Analysis of Variance. F $(4,1,4)$ ratio and probability (p) values.

\begin{tabular}{|c|c|c|c|c|c|c|c|c|c|c|c|c|}
\hline \multirow[t]{3}{*}{ Source } & \multicolumn{6}{|c|}{2010} & \multicolumn{6}{|c|}{2018} \\
\hline & \multicolumn{2}{|c|}{$\begin{array}{l}\text { Cluster } 1 \\
(20 \%)\end{array}$} & \multicolumn{2}{|c|}{$\begin{array}{l}\text { Cluster } 2 \\
(58 \%)\end{array}$} & \multicolumn{2}{|c|}{$\begin{array}{l}\text { Cluster } 3 \\
(28 \%)\end{array}$} & \multicolumn{2}{|c|}{$\begin{array}{l}\text { Cluster } 1 \\
(20 \%)\end{array}$} & \multicolumn{2}{|c|}{$\begin{array}{l}\text { Cluster } 2 \\
(51 \%)\end{array}$} & \multicolumn{2}{|c|}{$\begin{array}{c}\text { Cluster } 3 \\
(19 \%)\end{array}$} \\
\hline & $\mathrm{F}$ & $\mathrm{p}$ & $\mathrm{F}$ & $\mathrm{p}$ & $\mathrm{F}$ & $\mathrm{p}$ & $\mathrm{F}$ & $\mathrm{p}$ & $\mathrm{F}$ & $\mathrm{p}$ & $\mathrm{F}$ & $\mathrm{p}$ \\
\hline $\begin{array}{l}\text { Health } \\
\text { benefit }\end{array}$ & 11.9 & $<0.001$ & 20.7 & $<0.001$ & 28.3 & $<0.001$ & 8.3 & $<0.001$ & 4.5 & 0.001 & 5.6 & $<0.001$ \\
\hline $\begin{array}{l}\text { Manufacture } \\
\text { type }\end{array}$ & 28.1 & $<0.001$ & 50.3 & $<0.001$ & 8.4 & 0.004 & 1.1 & 0.302 & 5.0 & 0.026 & 1.0 & 0.311 \\
\hline $\begin{array}{l}\text { Health } \\
\text { benefit } \mathrm{x}\end{array}$ & & & & & & & & & & & & \\
\hline $\begin{array}{l}\text { Manufacture } \\
\text { type }\end{array}$ & 0.9 & 0.486 & 0.6 & 0.663 & 3.1 & 0.016 & 0.2 & 0.944 & 0.1 & 0.981 & 0.2 & 0.960 \\
\hline
\end{tabular}


Consumers in $\mathrm{C} 1$ showed to slightly increase their interest when cheese was low fat while having fibre and bifidus decreased their interest compared to regular cheese. These consumers showed to be more interested on traditional manufacture.

a)

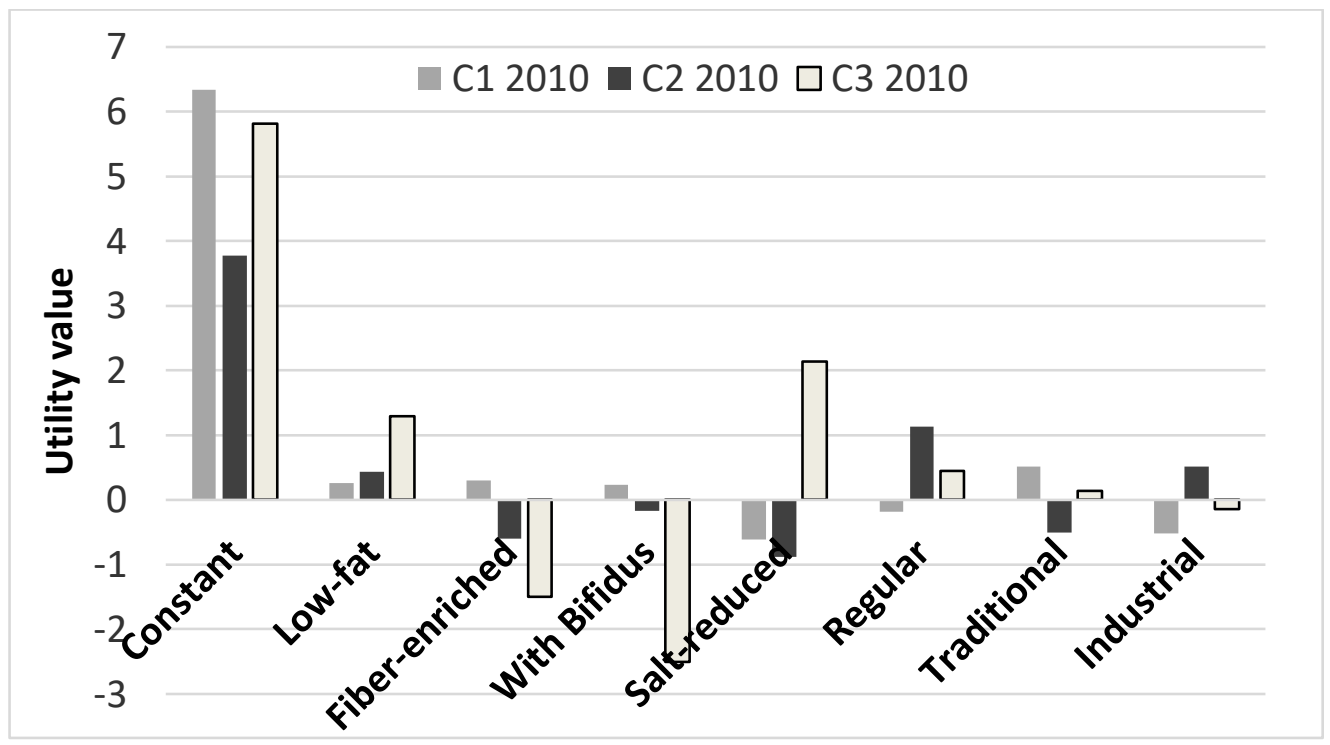

b)

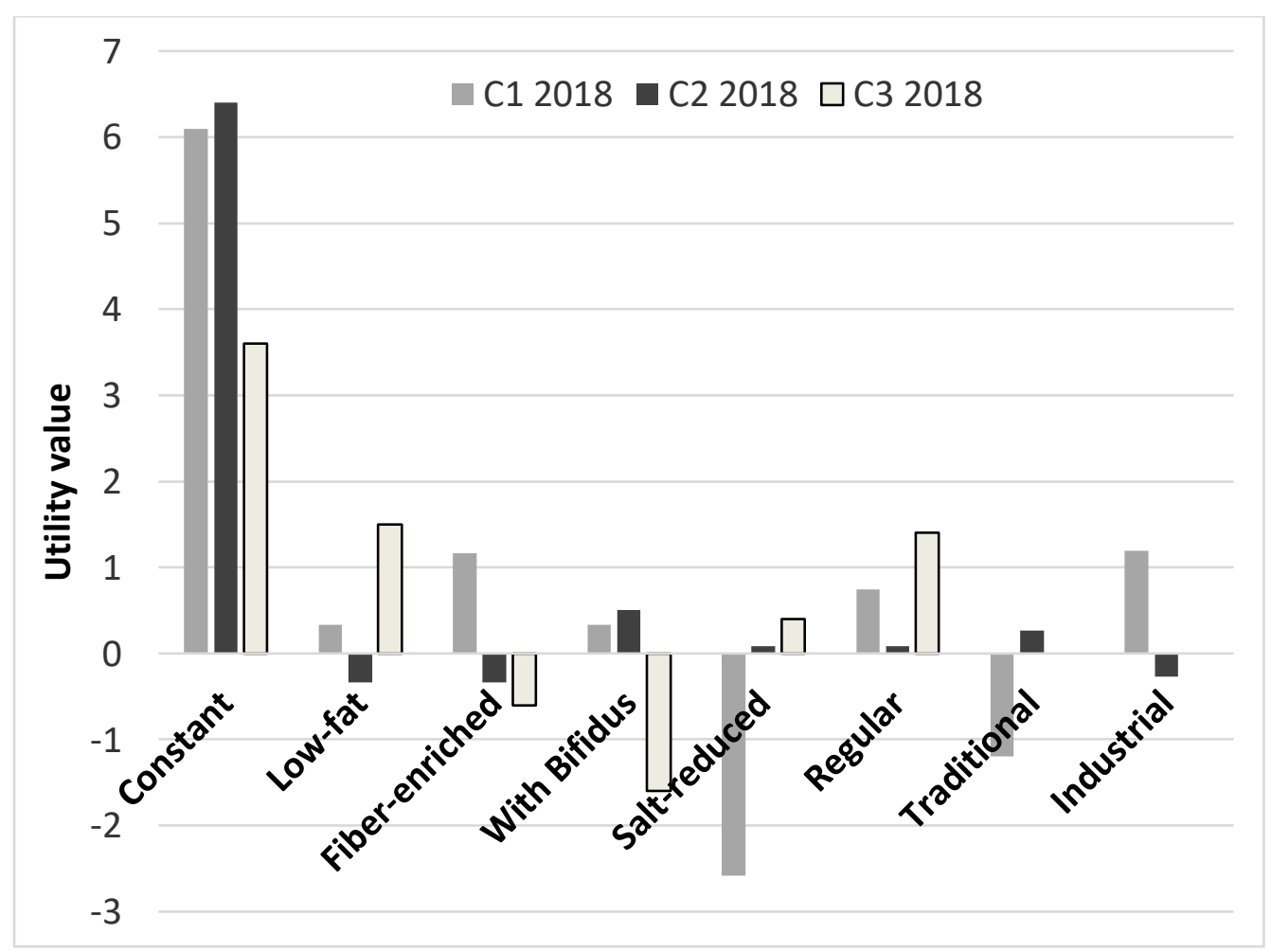

Figure 1. Utility value for clusters in spreadable cheese in 2010 (a) and 2018 (b).

Consumers in $\mathrm{C} 2$, were interested in low-fat and bifidus cheeses as much as in regular cheese and they clearly preferred industrial manufacture than traditional. 
For consumers in cluster C3, healthy benefits highly decreased their interest in spreadable cheese, especially having fibre. These consumers were only interested on regular cheese (high utility value). These consumers also preferred industrial manufacture than traditional.

\section{Survey conducted in 2018}

Similarly, to 2010, ANOVA showed that in general the interest of consumers in spreadable cheese varied significantly depending on the health benefit. According to the utility values, they were interested in low-fat products as well as the regular one and not interested in the other health benefits. According to t-test, there was no significant difference between the utility values of 2010 and 2018 (Table 3)

Three different groups of consumers were identified. In this case, the interest of consumers varied with the health benefit in the three clusters and the manufacture type only was significant in C2 (Table 4). Size and sense of utility values are shown in Figure $1 b$.

Consumers in $\mathrm{C} 1$ were interested in cheeses fibre enriched next to the regular cheese and then by the low-fat and with bifidus. They were not interested in salt-reduced. These consumers preferred the industrial manufacture more than traditional.

Consumers in $\mathrm{C} 2$ showed to slightly increase their interest when cheese was with bifidus while having fibre and low-fat decreased their interest compared to regular cheese. These consumers showed to be more interested in traditional manufacture.

Consumers in cluster C3 were interested in regular cheese followed by low-fat and saltreduced. They were not interested in fibre or bifidus. These consumers were indifferent to the type of manufacture.

\section{Consumers' interest in semi-soft cheese with different benefits and type of manufacture}

\section{Survey conducted in 2010}

ANOVA results (Table 2) of the total dataset showed that in general the interest of consumers in semi-soft cheese varied significantly depending on the health benefit. In this case, although the utility value of low-fat benefit was positive, it was significantly lower than for the regular cheese (Table 5). Compared to regular cheese low fat slightly increased the interest of these consumers while having fibre and bifidus slightly decreased 
the interest. In general, they showed to be more slightly interested on industrial manufacture.

Cluster analysis was applied, three groups of consumers were identified (Table 6). ANOVA showed that the effect of health benefit was significant in all the three clusters but manufacture type was significant only for one cluster (C1) (Table 6). Size and sense of utility values are shown in Figure 2a.

Table 5 Values of the parameters of the utility model for Danbo cheeses in relation with health benefits and processing type.

\begin{tabular}{|c|c|c|c|}
\hline \multirow[t]{2}{*}{ Factor } & \multirow[t]{2}{*}{ Level } & \multicolumn{2}{|c|}{ Utility values } \\
\hline & & 2010 & 2018 \\
\hline \multirow{5}{*}{ Health benefit } & Low-fat & $0.68^{\mathrm{b}, *}$ & $0.40^{\mathrm{b}, *}$ \\
\hline & Fibre-enriched & $-0.46^{c}$ & $-0.62^{c}$ \\
\hline & With Bifidus & $-0.67^{c}$ & $-0.53^{c}$ \\
\hline & Salt-reduced & $-0.73^{c}$ & $-0.48^{c}$ \\
\hline & None (regular) & $1.34^{\mathrm{a}, *}$ & $1.23^{\mathrm{a}, *}$ \\
\hline \multirow{2}{*}{ Process } & Industrial & $0.12^{\mathrm{a},{ }^{*}}$ & $-0.20^{a, *}$ \\
\hline & Traditional & $-0.12^{a, *}$ & $0.20^{\mathrm{b}, *}$ \\
\hline
\end{tabular}

Table 6. Influence of information about health benefit and manufacture type on consumer interest on Danbo cheeses in 2010 and 2018. Results of Analysis of Variance. F (4, 1, 4) ratio and probability $(\mathrm{p})$ values.

\begin{tabular}{|c|c|c|c|c|c|c|c|c|c|c|c|c|}
\hline \multirow[t]{3}{*}{ Source } & \multicolumn{6}{|c|}{2010} & \multicolumn{6}{|c|}{2018} \\
\hline & $\begin{array}{l}\text { Cluster 1 } \\
(42 \%)\end{array}$ & \multicolumn{2}{|c|}{$\begin{array}{l}\text { Cluster } 2 \\
(38 \%)\end{array}$} & \multicolumn{3}{|c|}{$\begin{array}{l}\text { Cluster } 3 \\
(20 \%)\end{array}$} & \multicolumn{2}{|c|}{$\begin{array}{l}\text { Cluster } 1 \\
(42 \%)\end{array}$} & \multicolumn{2}{|c|}{$\begin{array}{l}\text { Cluster } 2 \\
(39 \%)\end{array}$} & \multicolumn{2}{|c|}{$\begin{array}{l}\text { Cluster } 3 \\
(19 \%)\end{array}$} \\
\hline & $\mathrm{F}$ & $\mathrm{P}$ & $\mathrm{F}$ & $\mathrm{p}$ & $\mathrm{F}$ & $\mathrm{p}$ & $\mathrm{F}$ & $\mathrm{p}$ & $\mathrm{F}$ & $\mathrm{p}$ & $\mathrm{F}$ & $\mathrm{p}$ \\
\hline Health benefit & 20.2 & $<0.001$ & 32.6 & $<0.001$ & 51 & $<0.001$ & 7.1 & $<0.001$ & 9.1 & $<0.001$ & 8.4 & $<0.001$ \\
\hline Manufacture type & 19.2 & $<0.001$ & 2.7 & 0.102 & 0.0 & 0.900 & 3.0 & 0.049 & 0.9 & 0.348 & 1.0 & 0.328 \\
\hline $\begin{array}{l}\text { Health benefit } x \\
\text { Manufacture type }\end{array}$ & 0.9 & 0.459 & 0.8 & 0.502 & 2.6 & 0.038 & 0.2 & 0.933 & 0.7 & 0.596 & 0.2 & 0.953 \\
\hline
\end{tabular}


a)

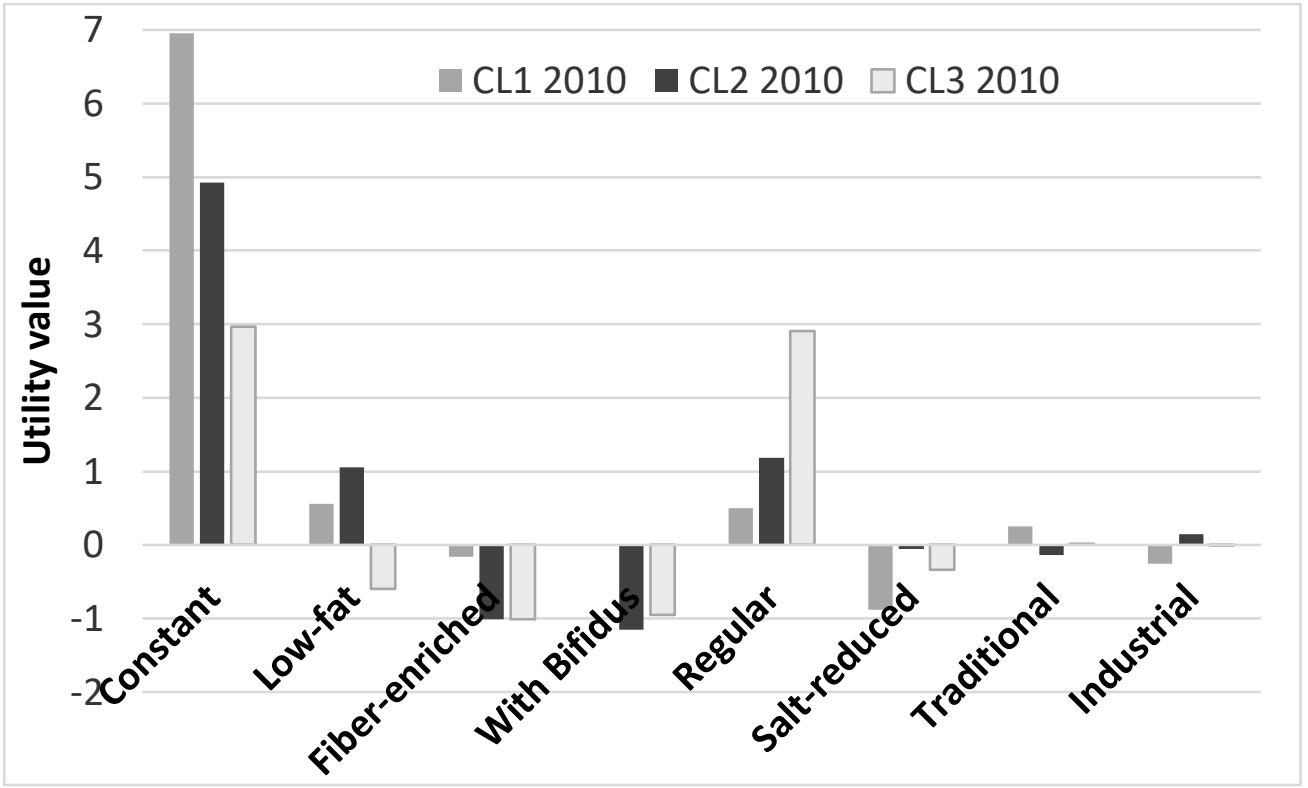

b)

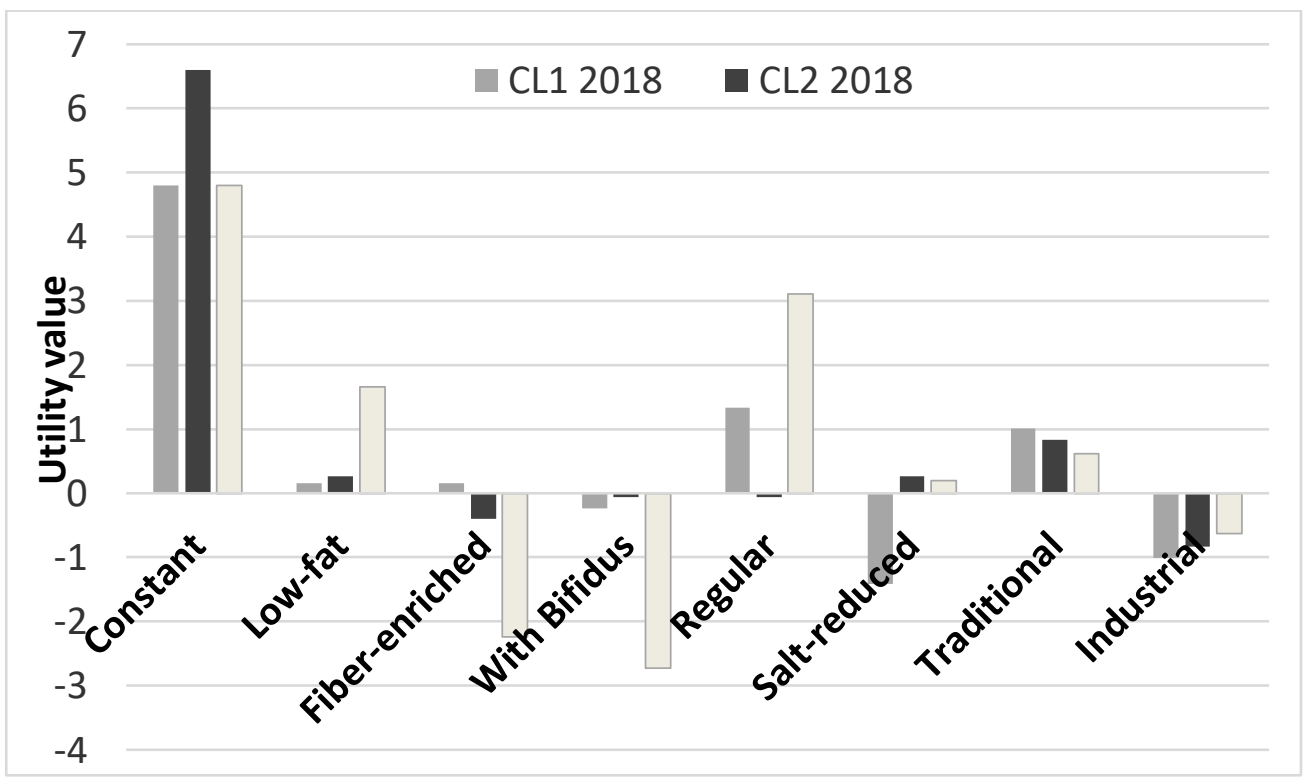

Figure 2. Utility value for clusters in Danbo cheese in 2010 (a) and 2018 (b).

\section{Survey conducted in 2018}

Similarly, to 2010, ANOVA showed (Table 2) that in general the interest of consumers in Danbo cheese varied significantly depending on the health benefit. Compared to regular cheese low fat slightly increased the interest of these consumers while having fibre and bifidus slightly decreased the interest. In general, they showed to be more slightly interested on traditional manufacture. 
According to t-test, there were significant differences between the utility values of lowfat and none benefit and type of manufacture between 2010 and 2018 (Table 4) C1 were interested only in the regular cheese, and highly rejected salt-reduced. C2 liked Danbo cheese in general (a high constant value), being indifferent to health benefits and C3 were interested only in the regular and low-fat cheese, and highly rejected fibre and bifidus. All clusters showed preference to traditional manufacture than industrial.

\section{Impact of time on the interest of new products with different nutritional benefits and type of manufacture.}

Regarding the health benefits, ANOVA results of 2010 show a significant effect on consumers' interest in spreadable cheese and Danbo cheese (Table 2).For both cheeses, the manufacture type had no significant effect on consumers interest. For the two types of cheeses, the interaction between the two factors was not significant indicating that their interest in the nutritional benefit of the cheeses did not depend on cheese processing type. The passage of time did not affect both cheeses in the same way. For the spreadable cheese the same results were observed eight years later (2018). In the case of Danbo cheese manufacture type effect became significant in 2018.

To determine the utility value for each of the studied characteristics for 2010 and 2018 for spreadable cheese and Danbo cheese a model relating consumers' interest and the different factor levels was obtained (Table 3 and Table 5 respectively).

For both types of cheeses and both periods of time, positive utility values were obtained for low-fat and regular products and negative utility values for the other three options (probiotic, fibre enriched and salt-reduced).

For spreadable cheese, consumers were interested in low-fat products as well as the regular one, with no change between 2010 and 2018. For Danbo cheese, the utility for low fat products was significantly lower than that for the regular product, for both 2010 and 2018. Danbo cheese is a popular semi-hard-pressed cheese, smear-ripened with $30 \%$ or $45 \%$ fat in dry matter and a distinctive flavour (John Sorensen \& Connie Benfeldt, 2001). This characteristic, in comparison with a spreadable cheese may influence Danbo cheese's consumers to be less liable to accept changes in the concept of the product. Spreadable cheese is a fresh cheese which is frequently consumed as milk-based commodities. It has been studied as a carrier of bioactive compounds. Lucera et al., (2018) enriched spreadable cheese with flours from by-products as sources of fibre and 
antioxidant compounds and Repajić et al., (2019) investigate sensory properties of spreadable cheese fortified with olives reporting. These authors reported that products have good potential as a functional product with favorable sensory characteristics that can satisfy consumer's demands.

In general, results show that consumers were interested only in the low-fat cheeses with no change for both 2010 and 2018, and they were not interested in the other nutritional alternatives considered in this study. Similar results for reduced fat cheeses were observed by Szakály et al., 2020. They found that the "health halo" effect worked in the case of cheese tested in Hungary. In this case, these authors show that reduced fat and salt cheeses were perceived as healthier, but they were associated with considerably less sensory pleasure, these may affect the purchase intention in some group of people. They inform that between health promoting variants they would be willing to purchase primarily the one with reduced fat.

With respect to the effect of the processing type, it was not significant for spreadable cheese for any period of time. In the case of Danbo cheese, processing type effect became significant in 2018, being positive for the traditional type. Soares 2017, found that manufacturing method was one of the main categories for differentiating consumers' perceptions from different areas from Brazil.

To identify different patterns in consumer response, hierarchical cluster analysis may be performed to segment consumers according to their interest.In this way, Almli et al., (2015) studied the preferences of Norwegian consumers on semi hard cheese and reported that consumers were divided in two groups. One that, on average, prefers cheeses of new (healthier) fat composition, organic production and lower price to cheeses of regular fat composition, conventional production and higher price. Consumers in the New fat segment are health-conscious, whereas consumers in the Regular fat segment are attracted by conventional cheese and lower prices. About manufacture type, Nicolosi et al., 2019 studied buying purchase habits of Swedish consumers, showing that there were two large groups among which were those who prefer to continue buying industrial cheeses and another emergent group that purchase local artisan cheeses. This last group appreciates artisan cheeses and choose them for their versatility, and because they wish to contribute to supporting the local economy.

In this work, to identify the possible different patterns in consumer response to cheeses, hierarchical cluster analysis was performed to segment consumers according to their interest for the different cheeses It was considered both type of cheese, the spreadable and 
Danbo and both years, 2010 and 2018. For spreadable cheese, three groups of consumers were identified. For all of them, both factors significantly affected their interest in the product in 2010 (Table 4). In 2018 for the three-group health benefit was significant but for manufacturing type there were two groups where this effect was not significant. The utility values obtained from the model for each group and for both years were calculated and a principal component analysis was assay (Figure 1). For spreadable cheese it can be seen that the clusters analyzed in 2010 have similar behavior that clusters analyzed in 2018. A group of consumers (C1 2010 and C2 2018) where the value of the constant of the model was high (6.3 and 6.4 respectively). The high value of the constant, indicate that these consumers were interested in spreadable cheeses in general. They also were slightly interested in cheeses with bifidus and fibre enriched and rejected low fat and saltreduced cheeses. A second group of consumers (C2 2010 and C1 2018) were the most relevant was that they preferred industrial cheeses over the traditional ones. And the third group of consumers composed by C3 2010 and C3 2018 that prefer low fat (and salt reduced to C3 2010) and reject fibre enriched and bifidus.

For Danbo cheese three groups of consumers for each year analyzed were identified too (Table 6). Health benefits were significant for all groups in 2010 and 2018. For manufacturing type in both years only 1 group was significantly affected by manufacturing type in 2018. The utility values were calculated and a principal component analysis was assay (Figure 2). In this case, clusters found in 2010 have different behavior than those found in 2018. In 2010 we found two groups (C2 2010 y C3 2010) interested in industrial danbo cheese and salt-reduced and C1 2010 interested in fibre enriched and bifidus. In 2018 (C1 2018 and C2 2018) were interested in traditional cheese and C3 2018 only interested in normal low fat Danbo cheese.

According to Ares et al., 2010, Uruguayan consumers have a greater intention of purchasing functional yogurts than regular yogurts. However, the results of the present study showed that for cheeses the information about the health benefits did not provide a higher utility value than that of the regular product. This suggests that a health benefit in these two types of cheese, spreadable and Danbo cheese was not considered as an added value by Uruguayan consumers or they do not find cheeses as an interesting carrier for functional ingredients. And this behavior remained mostly unchanged after eight years. Uruguayan cheese consumers did not change their habits in this period of time.

Differences observed between consumer response to yogurt and cheese would confirm the idea that consumers react differently to functional benefits among different food types 
(Urala \& Lähteenmäki, 2007). Yogurt can be considered a healthy product, and consumers are familiar with new varieties of the product (taste and composition) while cheese is considered a more traditional product, which is well accepted in itself.When consumers made choices between conventional and functional food products, their reasons to choose functional food are different within the different food categories (Urala and Lähteenmäki, 2004)

\section{Consumer characteristics affecting response to cheeses with health benefits.}

Some consumer characteristics such as gender, age and personal attitude toward a healthy diet can influence consumer responses toward a product with health benefits. In the present study, consumer distribution according to gender, age and the interest in a healthy diet in each cluster was analyzed for the spreadable and the Danbo cheese in 2010 and 2018 (Tables 7 and 8). For all cases, differences in consumer behavior were not related with the variation in age.

Table 7. Distribution of consumers (\%) on clusters for spreadable cheese in 2010 and 2018, according to gender, age and interest on healthy diet. Difference among proportions test, $\chi^{2}$ and probability $(\mathrm{p})$ values.

\begin{tabular}{|c|c|c|c|c|c|c|c|c|c|c|c|}
\hline \multirow{2}{*}{ Characteristics } & \multirow{2}{*}{ Level } & \multicolumn{5}{|c|}{2010} & \multicolumn{5}{|c|}{2018} \\
\hline & & C 1 & $\mathrm{C} 2$ & C 3 & $\chi^{2}$ & $\mathrm{p}$ & C 1 & $\mathrm{C} 2$ & C 3 & $\chi^{2}$ & $\mathrm{p}$ \\
\hline \multirow{2}{*}{ Gender } & M & $28^{a}$ & $37^{\mathrm{ab}}$ & $57^{b}$ & 9.3 & 0.011 & $8^{a}$ & $39^{b}$ & $55^{\mathrm{b}}$ & 50.1 & 0.001 \\
\hline & $\mathrm{F}$ & $72^{b}$ & $63^{\mathrm{ab}}$ & $43^{\mathrm{a}}$ & & & $92^{\mathrm{b}}$ & $61^{\mathrm{a}}$ & $45^{\mathrm{a}}$ & & \\
\hline \multirow{2}{*}{ Age } & 18 to 40 & 66 & 78 & 55 & 5.9 & 0.051 & 54 & 57 & 55 & 0.2 & 0.910 \\
\hline & 41 to 66 & 34 & 22 & 45 & & & 46 & 43 & 45 & & \\
\hline \multirow{3}{*}{$\begin{array}{l}\text { Interest in a } \\
\text { healthy diet }\end{array}$} & High & $47^{b}$ & $22^{a}$ & $30^{\mathrm{ab}}$ & 10.2 & 0.006 & 50 & 46 & 36 & 4.2 & 0.121 \\
\hline & Medium & 41 & 41 & 36 & 0.3 & 0.883 & 50 & 51 & 64 & 4.9 & 0.085 \\
\hline & Low & $12^{\mathrm{a}}$ & $37^{\mathrm{b}}$ & $34^{\mathrm{b}}$ & 10.8 & 0.004 & $0^{\mathrm{a}}$ & $3^{b}$ & $0^{\mathrm{a}}$ & 6.1 & 0.048 \\
\hline
\end{tabular}

$\overline{a-b}$ Within each row, percentage values followed by different letters are significantly different $(\mathrm{p} \leq 0.05)$.

To determine the interest in a healthy diet, a previous approach (unpublished data) was assay and the dimensionality of the responses to the General Health Interest Questionnaire was studied. These showed that for these Uruguayan consumers, the items corresponded 
to two different dimensions. The first dimension related to the theoretical importance that consumers gave to the diet-health relationship (items 2, 4, 5 and 6; Table 1) and a second dimension related to their actual eating behavior (items 1, 3,7 and 8; Table 1). According to these two dimensions, consumers were classified into three groups: high, medium and low interest. The group of consumers with high interest were those that considered the diet-health relationship to be important (sum of scores in dimension $1>14$ ) and consequently ate healthily (sum of scores on dimension $2>14$ ). The group of consumers who showed medium interest were those that did not follow a healthy diet (sum of scores on dimension $2 \leq 14$ ), despite considering the diet-health relationship important (sum of scores in dimension 1>14). Finally, consumers with low interest were those that did not consider as important the relation diet-health and did not eat healthily (sum of scores $\leq$ 14 for the two dimensions).

Table 8. Distribution of consumers (\%) on clusters for Danbo cheese in 2010 and 2018, according to gender, age an interest on healthy diet. Difference among proportions test, $\chi^{2}$ and probability (p) values.

\begin{tabular}{|c|c|c|c|c|c|c|c|c|c|c|c|}
\hline \multirow{2}{*}{ Characteristics } & \multirow{2}{*}{ Level } & \multicolumn{5}{|c|}{2010} & \multicolumn{5}{|c|}{2018} \\
\hline & & C 1 & C 2 & C 3 & $\chi^{2}$ & $\mathrm{p}$ & C 1 & C 2 & C 3 & $\chi^{2}$ & $\mathrm{p}$ \\
\hline \multirow{2}{*}{ Gender } & Male & $26^{a}$ & $41^{\mathrm{ab}}$ & $58^{b}$ & 9.1 & 0.011 & $43^{\mathrm{ab}}$ & $31^{\mathrm{a}}$ & $52^{b}$ & 9.1 & 0.01 \\
\hline & Female & $74^{b}$ & $59^{\mathrm{ab}}$ & $42^{\mathrm{a}}$ & & & $57^{\mathrm{ab}}$ & $69^{b}$ & $48^{a}$ & & \\
\hline \multirow{2}{*}{ Age } & 18 to 40 & 77 & 63 & 55 & 5.4 & 0.068 & 55 & 53 & 61 & 1.4 & 0.499 \\
\hline & 41 to 66 & 23 & 37 & 45 & & & 45 & 47 & 39 & & \\
\hline \multirow{3}{*}{$\begin{array}{l}\text { Interest in a } \\
\text { healthy diet }\end{array}$} & High & $44^{b}$ & $31^{\mathrm{ab}}$ & $19^{\mathrm{a}}$ & 6 & 0.049 & 49 & 33 & 43 & 5.4 & 0.071 \\
\hline & Medium & 41 & 40 & 32 & 0.7 & 0.700 & $49^{a b}$ & $65^{\mathrm{b}}$ & $48^{a}$ & 7.3 & 0.026 \\
\hline & Low & $15^{\mathrm{a}}$ & $29^{a b}$ & $49^{b}$ & 11.9 & 0.003 & $2^{a}$ & $2^{a}$ & $9^{b}$ & 7.9 & 0.019 \\
\hline
\end{tabular}

${ }^{\mathrm{a}-\mathrm{c}}$ Percentage values in rows followed by different letters are significantly different $(\mathrm{p} \leq 0.05)$.

For both, the spreadable cheese and the Danbo cheese, same behavior was observed. There were two clusters in each year (for $2010 \mathrm{C} 1$ and C2; for $2018 \mathrm{C} 1$ and C2) composed mostly by women with a high to medium interest in a healthy diet. For the other side, C3 2010 and C3 2018 was mostly composed by men with a medium (to low in 2010) interest in a healthy diet, which were only interested in the low-fat y salt-reduced functionality. This agrees with previous studies reporting that acceptability of functional foods varies 
with gender in Uruguay (Ares \& Gámbaro, 2007). Martins et al., 2020 showed that women expressed greater interest in consuming organic foods enriched with functional properties compared to men in Brazil. It is widely reported women are more interested in eating healthily than men (Gök et al., 2019).

Although the general trends in 2010 remains in 2018, it is interesting to note how the interest in a healthy diet grew from low to medium high over this period of time.

\section{CONCLUSION}

The interest of Uruguayan consumers in spreadable and Danbo cheese significantly varied when a health benefit is indicated. In Danbo cheese, health claims did not cause an increase in Uruguayan consumers' interest over the regular product in 8 years but manufacture type became significant between years, nowadays consumers are more interested in traditional manufacture. However, there is a group of consumers who were willing to consume cheeses with certain health benefits; low-fat cheese in particular was the most appealing to consumers, especially in the case of spreadable cheese. Type of product influenced response of consumer to different nutritional benefits and manufacture type. In this work could be observed how consumers were more liable to accept changes in a spreadable cheese, a fresh cheese which is frequently consumed as milk-based commodities, in spite of a Danbo cheese, a popular semi-hard-pressed cheese. With respect to the interest of consumers in having a healthy diet, it was observed and increased in the interest of them, reducing significant people with low concern in a healthy diet.

\section{ACKNOWLEDGMENTS}

The financial support of Generalitat Valenciana (Project Prometeo 2017/1 89) and LATU, Uruguay for Arcia's stay at IATA, are all gratefully acknowledged.

\section{REFERENCES}

Annunziata, A. \& Vecchio, R. (2011). Functional foods development in the European market: A consumer perspective. J. Funct. Foods, 3, 223-228.

10.1016/j.jff.2011.03.011. 
Almli, V.L., Øvrum, A., Hersleth, M., Almøy, T., Næs, T. (2015). Investigatin individual preferences in rating and ranking conjoint experiments. A case study on semi-hard cheese. Food. Qual. Prefer., 39, 28-39. 10.1016/j.foodqual.2014.06.011.

Ares, G. \& Gámbaro, A. (2007). Influence of gender, age and motives underlying food choice on perceived healthiness and willingness to try functional foods. Appetite, 49, 148-158. 10.1016/j.appet.2007.01.006.

Ares, G., Giménez, A. \& Gámbaro, A. (2008). Influence of nutritional knowledge on perceived healthiness and willingness to try functional foods. Appetite, 51, 663668. 10.1016/j.appet.2008.05.061.

Ares, G., Giménez, A. \& Deliza, R. (2010). Influence of three non-sensory factors on consumer choice of functional yogurts over regular ones. Food. Qual. Prefer., 21, 361-367. 10.1016/j.foodqual.2009.09.002.

Awaisheh, S. S. (2011). Development of probiotic soft cheese manufactured using goat's milk with the addition of thyme. Milchwissenschaft, 66, 51-54.

Ballco, P., Caputo, V., de-Magistris, T. (2020). Consumer valuation of European nutritional and health claims: Do taste and attention matter? Food. Qual. Prefer. 79, 103793. 10.1016/j.foodqual.2019.103793.

Bimbo, F., Bonanno, A., Nocella, G., Viscecchia, R., Nardone, G., De Devitiis, B., Carlucci, D. (2017). Consumers' acceptance and preferences for nutritionmodified and functional dairy products: A systematic review. Appetite, 113, 141154. 10.1016/j.appet.2017.02.031.

Bogue, J., O. Collins, O., A.M. Troy, A.M. (2017). Market analysis and concept development of functional foods. D. Bagchi, S. Nair (Eds.), Developing new functional food and nutraceutical products, Elsevier Science Publishing Co Inc, Cambridge. 29-45.

Drewnowski, A., Aggarwal, A., Hurvitz, P., Hastert, T., \& Moudon, A.V. (2010). The Perceived Importance of a Healthy Diet Predicts Retail Outlet Choice, Food Purchases and Body Weight. J. Am. Diet. Assoc., 110, A13.

Domínguez Díaz, L., Fernández-Ruiz, V., Cámara, M. (2020). An international regulatory review of food health-related claims in functional food products labeling. J. Funct. Foods, 68, 103896. 10.1016/j.jff.2020.103896.

Fritzen-Freire, C. B., Müller, C. M. O., Laurindo, J. B., \& Prudêncio, E. S. (2010). The influence of Bifidobacterium Bb-12 and lactic acid incorporation on the properties 
of Minas Frescal cheese. J. Food Eng., 96, 621-627. 10.1016/j.jfoodeng.2009.09.010.

Gök, İlkay \& Ulu, Efe. (2019). Functional foods in Turkey: marketing, consumer awarenessand regulatory aspects. Nutrition \& Food Science, 49,4, 668-686. 10.1108/NFS-07-2018-0198.

Guttierrez, R. \& Barreto, A. L. (2010). Characterization of Requeijao cheese potentially prebiotic by the addition of inulin and soy protein. Boletim do Centro de Pesquisa e Processamento de Alimentos, 28: 289-302.

Kaur A, Scarborough P, Rayner M. A (2017). Systematic review, and meta-analyses, of the impact of health-related claims on dietary choices. Int. J. Behav. Nutr. Phys. Act., 11;14(1): 93. 10.1186/s12966-017-0548-1.

Levy, K. J. (1975). Large-sample pair-wise comparisons involving correlations, proportions, or variances. Psychol. Bull., 82(2), 174-176. 10.1037/h0076377.

Lucera, A. \& Costa, C. (2018). Fruit and Vegetable By-Products to Fortify Spreadable Cheese. Antioxidants, 7 (5), 61. 10.3390/antiox7050061.

Martins, A., Bezerra, M. Junior, S., Brito, A., Neto, J., Galvao, J., Geraldo, J., Dorgival, J., Rangel, A. (2020). Consumer behavior of organic and functional foods in Brazil. Food Sci. Technol., 40, 2. 10.1590/fst.03519.

Menrad, K. (2003). Market and marketing of functional food in Europe. J. Food Eng., 56, 181-188. 10.1016/S0260-8774(02)00247-9.

Moskowitz, H., Beckley, J., \& Minkus-McKenna, D. (2004). Use of conjoint analysis to assess web-based communications on functional foods. Appetite, 43, 85-92. 10.1016/j.appet.2004.03.003.

Moskowitz, H. \& Silcher, M. (2006). The applications of conjoint analysis and their possible uses in Sensometrics. Food. Qual. Prefer., 17, 145-165. 10.1016/j.foodqual.2005.07.006.

Ngapo, T.M., Dransfield, E. (2006). British consumers preferred fatness levels in beef: Surveys from 1955, 1982 and 2002. Food. Qual. Prefer., 17(5), 412-417. 10.1016/j.foodqual.2005.05.006.

Nicolosi, A., Laganà, V.R., Laven, D., Marcianò, C., Skoglund, W. (2019). Consumer Habits of Local Food: Perspectives from Northern Sweden. Sustainability, 11, 6715. 10.3390/su11236715. 
Repajić, M., Grudenić, A., Levaj, B. (2019). Functional and sensory properties of olives fortified spreadable cheese. Mljekarstvo, 69(2), 125-137. 10.15567/mljekarstvo.2019.0205.

Rodrigues, D., Rocha-Santos, T. A. P., Pereira, C. I. Gomes, A. M., Malcata, F, X., \& Freitas, A. C. (2011). The potential effect of FOS and inulin upon probiotic bacterium performance in curdled milk matrices. LWT - Food Science and Technology, 44, 100-108. 10.1016/j.lwt.2010.05.021.

Roininen, K., Lähteenmäki, L., \& Tuorila, H. (1999). Quantification of Consumer Attitudes to Health and Hedonic Characteristics of Foods. Appetite, 33, 71-88. 10.1006/appe.1999.0232.

Siró I, Kàpolna E, Kàpolna B and Lugasi A. (2008). Functional food. Product development, marketing, and consumer acceptance-A review. Appetite 51: 456467. 10.1016/j.appet.2008.05.060.

Soares E.K.B., Esmerino E.A., Ferreira M.V.S., da Silva M.A.A.P., Freitas M.Q., Cruz A.G. (2017). What are the cultural effects on consumers' perceptions? A case study covering coalho cheese in the Brazilian northeast and southeast area using word association. Food Res. Int., 102, 553 - 558. 10.1016/j.foodres.2017.08.053.

Sorensen, J. \& Benfeldt, C. (2001). Heat treatment of cheese milk: Effect on proteolysis during cheese ripening. Int. Dairy Jl, 11(4-7), 567-574. 10.1016/S09586946(01)00078-4.

Szakály Z., Soós M., Balsa-Budai N., Kovács S., Kontor E. (2020). The Effect of an Evaluative Label on Consumer Perception of Cheeses in Hungary. Foods, 9:563. 10.3390/foods 9050563 .

Turkmen, N. Akal, C., Özer, B. (2019). Probiotic dairy-based beverages: A review. J. Funct. Foods, 53, 62-75. 10.1016/j.jff.2018.12.004.

Urala, N., \& Lähteenmäki, L. (2004). Attitudes behind consumers' willingness to use functional foods. Food. Qual. Prefer., 15, 793-803. 10.1016/j.foodqual.2004.02.008.

Urala, N., \& Lähteenmäki, L. (2007). Consumers' changing attitudes towards functional foods. Food. Qual. Prefer., 18, 1-12. 10.1016/j.foodqual.2005.06.007.

van Loo E.J., Grebitus C., Roosen J. (2019). Explaining attention and choice for origin labeled cheese by means of consumer ethnocentrism. Food. Qual. Prefer., 78, 103716. 10.1016/j.foodqual.2019.05.016. 
van Trijp, H.C.M., van der Lans, I.A. (2007). Consumer perceptions of nutrition and health claims. Appetite, 48, 3, 305 - 324. 10.1016/j.appet.2006.09.011.

Villegas, B. Carbonell, I. \& Costell, E. (2008). Effects of product information and consumer attitudes on responses to milk and soybean vanilla beverages. J. Sci. Food Agric., 88, 2426-2434. 10.1002/jsfa.3347. 


\section{CAPÍTULO 2. Uso del subproducto de la producción de jugo de arándano como fuente de fibra}




\title{
Blueberry pomace as a source of antioxidant fibre in cookies. Consumer's expectations and critical attributes for developing a new product.
}

\author{
Curutchet Ana ${ }^{\text {a }}$, Cozzano Sonia a ${ }^{\text {, Tárrega Amparo }}{ }^{\mathrm{c}}$, Arcia Patricia a,b* \\ a Departamento de Ciencia y Tecnología de Alimentos. Facultad de Ingeniería y Tecnologías \\ UCU, Comandante Braga 2715 (11600), Montevideo, Uruguay. \\ ${ }^{\mathrm{b}}$ Latitud - LATU Foundation, Av. Italia 6201 (11500), Montevideo, Uruguay.

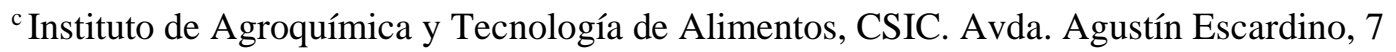 \\ (46980) Paterna (Valencia) Spain.
}

Food Science and Technology International, (2019), 25(8): 642-648 


\begin{abstract}
Valorisation of an agroindustry by-product, through its uses as an ingredient, in the development of a product may be an opportunity for industry to reduce wastes, generating a valuable product rich in bioactive compounds. Nevertheless, as happens with every new product, food manufacturers follow the market trend ensuring that any new product or idea meets consumer expectations. The aim of this work is to study the expectation and the acceptability of consumers towards fibre enriched cookies using blueberry pomace as a functional ingredient. A label for the blueberry cookies, created for this purpose, was evaluated by consumers who rated their expected liking when observing this label. Fibre enriched cookies were formulated using blueberry pomace powder as source ingredient for antioxidant dietary fibre. A cookie without fibre was evaluated as a reference. Cookies were evaluated by a group of consumers who rated their degree of liking when tasting the sample under blind and informed conditions. Results showed that the consumers expectations were not fulfilled when assessing the product. Acceptability scores of blueberry pomace, fibre enriched cookies show that most consumers are not willing to compromise hedonic aspects of cookies for their healthful attributes. Focus group was used to explore the characteristics a healthy cookie should have. Formulation of cookies must be optimised taking to account acceptability of consumers.
\end{abstract}

Keywords: blueberry by-product, fibre enriched cookie, label expectation, consumer acceptance, focus group. 


\section{INTRODUCTION}

Industrial residues of fruit and vegetable processing are a relevant source of bioactive compounds (Ignat et al., 2011), including the blueberry juice industry. The processing of blueberry into juice generates waste that may reach $20 \%$ of the initial fruit weight (Šarić et al., 2016). In most European legislations, production residues are defined as wastes, but scientists who investigate the potential of reusing food wastes define them as food by-products (Galanakis, 2012).

Definition of valorisation is the post processing of by-products incorporated in the production of other food products. Different ways of valorising by-products have been investigated with citrus, fish, meat, cereals, roots, and dairy(Banaszewska et al., 2014). Most of these studies focus on biotechnological developments and investigate the possibility of extracting nutrients from by-products and the possibility of using parts of these by-products in the production of new products.

Nevertheless, new products development can be challenging, and food manufacturers need to make sure that these new products and ideas meet consumer expectations (Tudoran et al., 2009; Urala and Lahteenmaki, 2007). A recent report estimates that the global market for foods with health-enhancing features amounted to approximately $\$ 168$ billion in 2013. With an annual average growth rate of $8.5 \%$ forecast to exceed $\$ 300$ billion by 2020 (Research and Markets, 2014). These market projections mask a high risk of product failure as 70 to $90 \%$ of new health-enhancing products disappear from the market within the first two years from their launch (Heasman and Mellentin, 2001; Stein and Rodríguez-Cerezo, 2008; Hardy et al., 2010; Bimbo et al., 2017). High failure rates can arise when not considering consumers' preferences and acceptance in the product development process (Van Kleef et al., 2002; 2005). Seen in findings from studies conducted in different contexts (Ozen et al., 2012; Ozen et al., 2014) or from a failure to communicate the functional benefits.

Although consumer sensory and hedonic perception of products has been regarded as a key predictor for food choice (Tuorila et al., 2007), other aspects of food consumption play a relevant role in consumers' decision-making process (Köster et al., 2009). Expectations that relate to the sensory and hedonic characteristics of products strongly influence consumer perception and decisions, both consciously and subconsciously (Piqueras-Fiszman and Spence, 2016). Expectations are created from earlier experiences and product information. This can lead consumers to believe that products have certain 
sensory features, or they will generate a specific level of pleasure (Deliza and MacFie, 1996). An inverse relationship between consumer perceived healthiness and tastiness has been reported in several studies (Bialkova, Sasse, \& Fenko, 2016; Fenko, Kersten, \& Bialkova, 2016).

Product packaging is one of the extrinsic aspects that can affect consumer buying behaviour, acting to attract attention and provide information, thus affecting perceived product quality (Deliza and MacFie, 1996; Ares and Deliza, 2010; Chrea et al., 2011; Carrillo, Varela, \& Fiszman, 2012; Reis et al., 2017).

So, to improve the likelihood of product acceptance, a holistic view is needed to consider consumer perception, to provide an integrated picture of the multiple elements affecting the preferences and acceptance of the consumers.

The aim of this work was to investigate valorisation of blueberry by-products with a straightforward process, used as an ingredient source of antioxidant fibre that could develop healthy foods. To conduct this investigation, the tasks were three-fold. First, to evaluate acceptability and expectations, created by a label for the cookies with blueberry pomace and their related functional claims. Second, to evaluate the impact of the blueberry by-product on consumers' acceptability of the cookies. Third, to find intrinsic characteristics of the product that drive consumers to choose a cookie with blueberry.

\section{MATERIALS AND METHODS}

\section{Experimental procedure}

Prior to developing a fibre enriched cookie using blueberry pomace, the expected liking of consumers was evaluated through with a blueberry cookie label created for this purpose. A control cookie, with no blueberry pomace powder was also evaluated (2.1.1.). Both labels, the enriched and the control cookies, presented the product as "without sugar added". This decision was taking in consideration the last tendency of reducing sugar consumption worldwide (Lustig, Schmidt, \& Brindis, 2012; Scientific Advisory Committee on Nutrition, 2014). Sugar has become a major hidden source of calories in a modern diet, with its intake has been strongly associated with the growing prevalence of several negative health conditions, such as, obesity, type-2 diabetes, and dental caries (Popkin and Nielsen, 2003: Morenga et al., 2013). 
After acceptance tests a fibre enriched cookie, with antioxidants and free of sugar, was developed (2.1.2.).

Cookies acceptability were evaluated by consumers who rated their degree of liking when tasting the sample under two different conditions (2.1.3.).

Finally, to understand consumer behaviour, the conduction of a focus group obtained characteristics of the "ideal healthy cookie" (2.1.4.).

\section{Expectations created by label}

\section{Label design}

Images of the cookies packaging for the fibre enriched, and the control cookies were used to communicate information about these products. Boxes were chosen for packaging the cookies and health claims were included on the labels. In the case of the fibre enriched cookies, the information stated was "with natural antioxidants" and the claim for fibre "source of fibre". For both the fibre enriched and the control cookies, the claim "no added sugar" was included on the label.

The labels did not correspond to any products available in the Uruguayan market to avoid any influence on consumers response. A professional graphic designer with experience designing food packaging designed the images of the cookie packaging, shown in Figure 1.
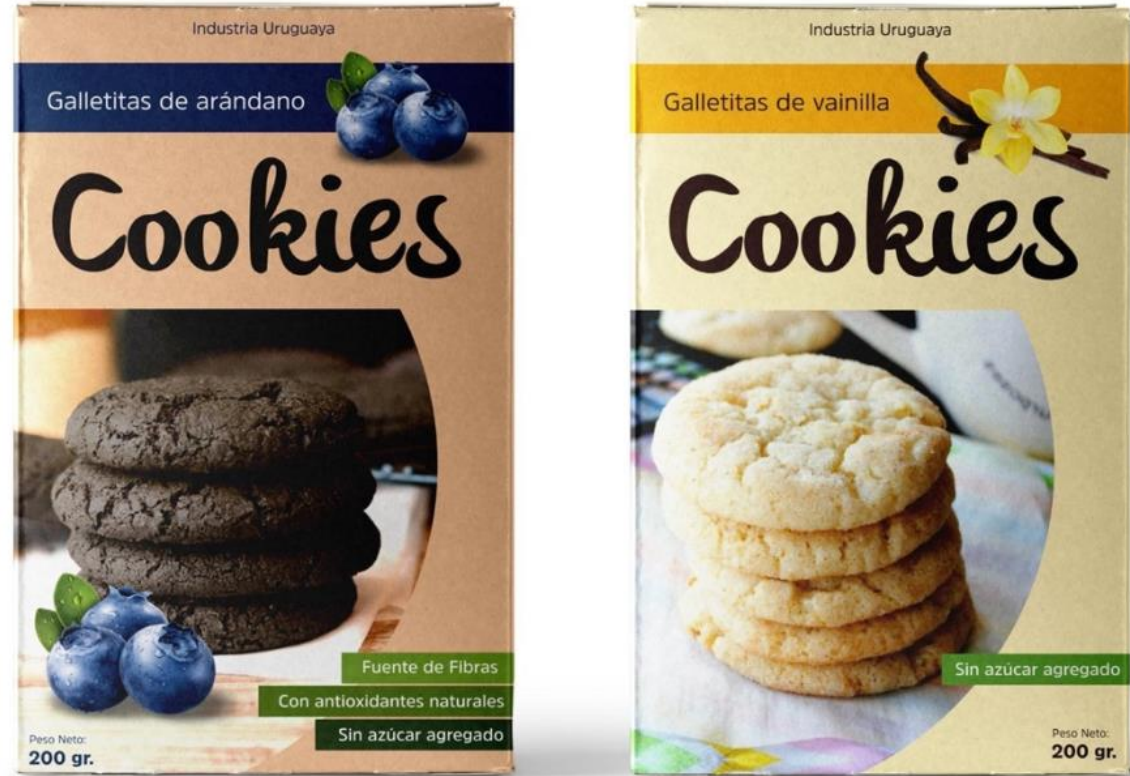

Figure 1. Cookie boxes figures used to convey information to the consumer. 


\section{Expectation evaluation}

A label evaluation task was upload to an on-line survey, completed by 330 persons, $30 \%$ men and 70\% women, with their ages ranging between 18 and 70 years old. Consumers were provided with the labels of the fibre enriched and control cookies and were asked to rate how much they considered they may like the product (expected condition).

\section{Cookie development}

A cookie was developed using blueberry pomace powder (BPP) as a source of bioactive compounds. In accordance to a previous study, BPP presents dietary fibre with antioxidant capacity (Perez et al., 2018).

The blueberry pomace was obtained as a by-product from juice production. The blueberries used were the O'Neill variety, from Uruguay. BPP was produced by drying blueberry pomace in a convection oven at $45 \pm 2{ }^{\circ} \mathrm{C}$ until $13 \mathrm{~g} / 100 \mathrm{~g}$ moisture content was achieved. When the pomace reached room temperature, it was ground in a laboratory mill (Retsch ZM 200), using only the fraction that passed through a $1 \mathrm{~mm}$ sieve.

\section{Cookie formulation}

The following ingredients were used for cookie preparation: blueberry pomace powder, wheat flour, water, vegetable oil, skimmed milk powder, commercial sucralose (Splenda ${ }^{\circledR}$, USA), whey protein concentrate $80 \%$ (Friesland Campina DMV, Netherlands), baking powder, vanilla flavour powder, and powdered soy lecithin (Archer Daniels Midland Company ADM, USA).

Cookie dough was prepared by mixing all ingredients together, according to Table 1, and were rolled out to a thickness of $0.50 \mathrm{~cm}$, followed by cutting discs of diameter $4 \mathrm{~cm}$. The cookie shaped dough was baked at $170{ }^{\circ} \mathrm{C}$ in a convection oven for twelve minutes. Perez et al. (2018) found that cookies with a 9\% dietary fibre (37.14 $\mathrm{g}$ of BPP in $100 \mathrm{~g}$ of total dry dough), in discs of $4 \mathrm{~cm}$ diameter and $0.5 \mathrm{~cm}$ height, baked at $170{ }^{\circ} \mathrm{C}$, presented the maximum antioxidant capacity and total polyphenol content according to the experiment design assayed. For the control, a cookie with no blueberry pomace powder was assayed.

\section{Acceptability of blueberry pomace cookies}

One month later, after the expectation study, consumers evaluated the fibre enriched and control cookies and their respective labels. Evaluations were done in two different sessions. 
Table 1. Cookie formulation

\begin{tabular}{lll}
\hline \multirow{2}{*}{ Ingredients } & \multicolumn{2}{c}{ Amount in the dough (\%) } \\
\cline { 2 - 3 } & BPP enriched cookie & Control cookie \\
\hline Wheat flour & 28.52 & 65.94 \\
Blueberry pomace powder & 37.14 & - \\
Sweetener & 2.29 & 2.29 \\
Whey protein concentrate & 1.91 & 1.91 \\
Vegetable oil & 17.49 & 17.49 \\
Skimmed milk powder & 10.00 & 10.00 \\
Vanillin & 0.95 & 0.95 \\
Baking powder & 1.43 & 1.43 \\
Soy lecithin powder & 0.28 & 0.66 \\
\hline
\end{tabular}

In the first session, consumers were asked to taste and evaluate the acceptability of cookies sample without information (blind condition); 96 consumers evaluated overall acceptability. The consumers included students and workers (33\% men and 67\% women, their ages ranged between 18 and 70 years old) of the Universidad Católica del Uruguay and were regular cookies consumers. One cookie of each sample was served to the consumers on plastic plates coded using a three-digit random number. The consumers evaluated overall acceptability with a nine-point scale ranging from "I dislike extremely" (“Me disgusta muchísimo") to "I like extremely" ("Me gusta muchísimo").

The second session took place two weeks later, when consumers were provided with each cookie sample and its corresponding label. Here they were asked to taste the sample and rate its acceptability, considering the label (informed condition). 110 consumers took part in this evaluation (30\% men and 70\% women and their ages ranged between 18 and 65 years old).

\section{Focus group}

Two focus groups were conducted to find the most important extrinsic and intrinsic characteristics that influenced cookie choices. Participants were recruited through convenience sampling of the Catholic University of Uruguay and the Latitud - LATU Foundation (Montevideo, Uruguay). 19 people took part (12 females and 7 males). Each focus group took place in separate rooms in the above-mentioned centres. All participants were frequent (more than once a week) cookies consumers.

Focus groups lasted 40 - 60 minutes, the audio was recorded for the sessions and later transcribed. 
An interview guide was used for both focus groups. The focus group started with an introduction to the session and a warm-up exercise. To find the most important characteristics for healthy cookie consumption, a two-step method was used.

First, participants were presented with eight different cookies, including samples of the local market and both cookies developed for this study (cookie fibre enriched with blueberry pomace and the control cookie). Participants were then allowed to handle, smell, and eat the cookies and asked to give comments for each one of the cookies. Finally, participants were asked to list three characteristics they consider the most important that drove them to buy healthy cookies.

\section{Statistical Analysis}

Differences between acceptability values for the "expected" and "blind" (E - B) conditions, between "informed" and "blind" (I - B) conditions, and between "informed" and "expected" (I - E) conditions were calculated. Their significant differences were determined by the t-Student test $(\alpha \leq 0.05)$. Analyses were performed using XLSTAT Version 2011 (Addinsoft 1995-2010, France).

\section{RESULTS AND DISCUSSION}

\section{Expected acceptability of cookies}

Considering the expected liking (E), consumers rated the fibre enriched cookie with a score of 6.9, with no significant difference to the reference cookie (score 7.0) (Table 2). Here the score reached an acceptable level in a 9-point hedonic scale according Muñoz, Civille, \& Carr (1992). These authors consider an acceptability score of 6.0 in a 9-point hedonic scale (the first score in the liking category) as a commercial or quality limit.

\section{Blind condition}

Consumers evaluated both, the fibre enriched and the control cookies, assigning a score of 5.3 and 5.5 respectively, in a 9-point scale, with no significant difference between them (Table 2). This evaluation was conducted by consumers with no information (blind condition). The low scores obtained showed that neither the fibre enriched, nor the control cookies reached an acceptable value in a 9-point hedonic scale according to Muñoz, Civille, \& Carr (1992). In the case of the fibre enriched cookie, the cookie colour (intense violet colour) may generate surprise in consumers. Regarding sensory characteristics, 
Perez et al., (2018) registered that the fibre enriched cookie with BPP was considered by the consumer as fruity, tasty, fibrous, and with an intense flavour. These characteristics are responsible for the low score obtained and the consumer not having any information about the cookie.

For the control cookie, the score was below 6 points. This response can be attributed to poor sensory characteristics for the lack of added sugar in the formulation, making consumers reject the cookie. Sugar reduction can influence taste and texture perception of products (van Raaij et al., 2009). In cookies, sugar is one of the major ingredients, having a crucial role in the structural and textural properties during cookie dough preparation and baking, providing a typical shape and texture to the final product (Biguzzi et al., 2014).

\section{Informed condition}

Under the informed condition, the liking scores of both cookies presented no significant differences, with scores of 5.7 for the fibre enriched and 5.3 for the control cookie (Table 2). As happened in the blind condition test, acceptability scores were low and indicated that samples were only slightly liked.

Table 2. Mean liking scores of acceptability and standard deviation for the two evaluated cookies samples for the three evaluation conditions considered.

\begin{tabular}{lccc}
\hline Sample & \multicolumn{3}{c}{ Acceptability } \\
\hline Fibre enriched cookie & Expected $(\mathrm{E})$ & Blind $(\mathrm{B})$ & Informed $(\mathrm{I})$ \\
Control cookie & $6.9^{\mathrm{ns}} \pm 1.8$ & $5.3^{{ }^{\mathrm{ns}} \pm 2.2}$ & $5.7^{{ }^{\mathrm{ns}} \pm 2.0}$ \\
\hline ns. Indicates that values are not significantly different $(\mathrm{p} \leq 0.05)$ according to $\mathrm{T}$ - Student test.
\end{tabular}

\section{Effect of expectative on acceptability}

To study the effect of expectations on the acceptability of cookies, mean scores for each sample were compared in the blind condition (B), the expected condition (E) and the informed condition (I). In the present study (Table 3) the difference between consumer expected liking and blind liking (E - B) was significant and positive. This means that the expected liking according to label was higher than the actual liking when tasting the product. In this study I - B was not significant, showing that the label information did not affect actual acceptability of the sample. 
Table 3. Means values (M) and significance ( $\mathrm{p}$, probability according $\mathrm{T}$ - test) of differences between acceptability values of samples obtained under different conditions. Blind $=\mathrm{B}$, Expected $=\mathrm{E}$ and Informed $=\mathrm{I}$.

\begin{tabular}{|c|c|c|c|c|}
\hline \multirow{2}{*}{ Sample } & \multicolumn{2}{|c|}{ E-B } & \multicolumn{2}{|c|}{$\mathrm{I}-\mathrm{B}$} \\
\hline & M & $p$ & M & $p$ \\
\hline \multirow{2}{*}{ Fibre enriched cookie } & 1.6 & $<0.001$ & 0.4 & 0.186 \\
\hline & \multicolumn{2}{|c|}{ Disconfirmation (-) } & \multicolumn{2}{|c|}{ n.s. } \\
\hline \multirow{2}{*}{ Control cookie } & 1.5 & $<0.001$ & -0.2 & 0.467 \\
\hline & \multicolumn{2}{|c|}{ Disconfirmation (-) } & \multicolumn{2}{|c|}{ n.s. } \\
\hline
\end{tabular}

These results reveal that the labelling the presence of blueberry pomace created good expectations on consumers. But it did not have an effect when consumers tasted the samples. For both cookies, consumers had positive expectations when observing the labels, but these had no effect on rated acceptability when they tasted the cookies. This was previously seen for other food products (Monaco et al., 2004; Varela et al., 2010; Villegas et al., 2008).

Labels may be used as a tool to detail information about product healthiness via nutritional information, health claims, quality logos, natural labels, among many others (Hawley et al., 2012; Lähteenmäki, 2013; Verbeke, Scholderer, \&Lähteenmäki, 2009; Reis et al. 2017). Previous studies have shown that package characteristics, and especially those related to the label, can influence, either positively or negatively, the overall image of the product and likewise product expectation, acceptability and consumer choice (Mueller and Szolnoki, 2010; Deliza et al., 2003; Torres et al., 2012; Varela et al.2010; Villegas et al., 2008).

Information relating to the reduction of ingredients content related to the expected sensory characteristics in a product has shown to influence consumers' hedonic expectations (Reis et al., 2017). With the cookies presented in this work, it should be noted that most of the consumers are not willing to compromise on sensory and hedonic aspects of products for their healthiness, as it was observed by Civille and Oftedal, (2012).

Results indicated that the enriched cookie with blueberry pomace did not meet the expectations of consumers and the optimisation of product characteristics, according to what consumers expect, is necessary. So, it was necessary to know what consumers think and feel about the intrinsic and extrinsic aspects of these 'kind of' healthy cookies. 


\section{Product characteristics affecting consumer acceptance}

A focus group was conducted to find factors that influence cookie choice and consumption.

Eight different healthy cookies, including samples from the local market and both cookies developed in this study (fibre enriched cookie with BPP and the control cookie) were presented to participants, with no information. Participants were invited to observe and to taste each cookie and comment on their impression for each of them.

Regarding the fibre enriched cookie with BPP, participants stated aspects as too soft, tasty, acid, and with strange colour. In the case of the control cookie, participants described it as soft, bland, dry, and healthy.

Participants mention the desirable sensory characteristics in these cookies as: thin, crunchy, and tasty, with these, the most important drivers for cookie acceptance based on these final lists of characteristics. Finally, when participants were asked about the characteristics that drive them to buy healthy cookies, the most often mentioned were healthier than regular ones, with fibre, without added sugar, low fat, without trans-fat, and low calorie. Participants also indicated that these characteristics relate to more expensive cookies than regular.

\section{CONCLUSIONS}

Consumer expectations and acceptability of cookies enriched with antioxidant fibre using a blueberry pomace by-product were studied. When observing labels, consumers gave liking scores for cookies with blueberries (showing fibre, antioxidant, and reduced sugar claims) like those of the reference vanilla cookie (reduced sugar claim).

Consumers have good expectations for this new product, but when they tasted the cookie with blueberry pomace, they did not like it and the information on its label did not significantly increase acceptability. Focus group sessions allowed discovery of intrinsic attributes (thin, crunchy, intense flavour and re-defined colour) that consumers expected to find in the product, and the strategies to optimise the product to assure the success in the market. 


\section{ACKNOWLEDGMENTS}

The authors are grateful to Serufox S.A. for providing the blueberries. To Syrah Design graphic design team (syrahdesign.com), for creating the cookies labels. To Generalitat Valenciana for funding of the project LINCE (Prometeo 2017/189)

\section{REFERENCES}

Ares, G., Deliza, R. (2010). Studying the influence of package shape and color on consumer expectation of milk desserts using word association and conjoint analysis. Food Quality and Preference, 21, 930-937.

Banaszewska, A., Cruijssen, F., Claassen, G.D.H., van der Vorst, J.G.AJ. (2014). Effect and key factors of byproducts valorization: The case of dairy industry, Journal of Dairy Science, 97, 4, 1893-1908.

Bialkova, S., Sasse, L., Fenko, A. (2016). The role of nutrition labels and advertising claims in altering consumers' evaluation and choice. Appetite 96, pp. 38-46.

Biguzzi, C., Schlich, P., Lange, C. (2014) The impact of sugar and fat reduction on perception and liking of biscuits. Food Quality and Preference, 35, 41 - 47.

Bimbo, F., Bonanno, A., Nocella, G., Viscecchia, R., Nardone, G., De Devitiis, B., Carlucci, D. (2017). Consumers' acceptance and preferences for nutritionmodified and functional dairy products: A systematic review, Appetite, 113, 141-154.

Carrillo, E., Varela, P., Fiszman, S. (2012). Effects of food package information and sensory characteristics on the perception of healthiness and the acceptability of enriched biscuits. Food Research International, 48, 209-216.

Chrea, C., Melo, L., Evans, G., Forde, C., Delahunty, C., Cox, D.N. (2011). An investigation using three approaches to understand the influence of extrinsic product cues on consumer behavior: An example of Australian wines. Journal of Sensory Studies. 26(1), 13-24.

Civille, C.V., Oftedal, K.N. (2012). Sensory evaluation techniques - make "good for you" taste "good". Physiology \& Behavior, 107, 598-605.

Deliza, R., MacFie, H. J. H. (1996). The generation of sensory expectation by external cues and its effect on sensory perception and hedonic ratings: A review. Journal of Sensory Studies, 11, 103-128. 
Deliza, R., Macfie, A., Hedderley, A. (2003). Consumer attitude towards information on non-conventional technology. Trends in Food Science and Technology. 14, 4349.

Fenko, A., Kersten, L., Bialkova, S. (2016) Overcoming consumer scepticism toward food labels: The role of multisensory experience. Food Quality and Preference 48, 81-92.

Galanakis, C.M. (2012), Recovery of high added-value components from food wastes: Conventional, emerging technologies and commercialized applications. Trends Food Science Technology, 26, 68-87.

Hardy, N. (2010). Future Innovations in Food and Drinks to 2015, Report No. BI00014024, Business Insights, London.

Hawley, K.L., Roberto, C.A., Bragg, M.A., Liu, P.J., Schwartz, M.B., Brownell, K.D.(2012). The science on front-of-package food label. Public Health Nutrition, 16, 430-439.

Heasman, M., Mellentin, J. (2001). The Functional Foods Revolution: Healthy People, Healthy Profits, Earthscan Publications Ltd, London.

Ignat, I., Volf, I., Valentin, I.P. (2011). A critical review of methods for characterization of polyphenolic compounds in fruits and vegetables. Food Chemistry, 126, 1821-1835.

Köster, E. P. (2009). Diversity in the determinants of food choice. A psychological perspective. Food Quality and Preference, 20(2), 70-82.

Lähteenmäki, L. (2013). Claiming health in food products. Food Quality and Preference, 27, 196-201.

Monaco, R., Cavella, S., Marzo, S. (2004). The effect of expectations generated by brand name on the acceptability of dried semolina pasta. Food Quality and Preference, $15,429-437$.

Morenga, L., Mallard, S., Mann, J. (2013). Dietary sugars and body weight: Systematic review and meta-analyses of randomized controlled trials and cohort studies BMJ, 346, e7492.

Muñoz A.M., Civille G.V., Carr B.T. (1992). Introduction. In Sensory Evaluation in Quality Control (1-22). Boston, MA: Springer US.

Mueller, S., Szolnoki, G. (2010). The relative influence of packaging, labelling, branding and sensory attributes on liking and purchase intent: Consumers differ in their responsiveness. Food Quality and Preference, 21, 774- 783. 
Lustig, R.H., Schmidt, L.A., Brindis, C.D. (2012) Public health: The toxic truth about sugar. Nature, 482(7383), 27-29.

Özen, A. E., Pons, A., \& Tur, J.A. (2012). Worldwide consumption of functional foods: a systematic review. Nutrition Reviews, 70, 472-481.

Özen, A. E., Bibiloni, M., Pons, A., Tur, J. A. (2014). Consumption of functional foods in Europe; a systematic review. Nutricion Hospitalaria, 29(3), 470-478.

Popkin, B.M., Nielsen, S.J. (2003). The sweetening of the world's diet. Obesity Research 11:1325-32.

Piqueras-Fiszman, B., \& Spence, C. (2016). Sensory expectations based on productextrinsic food cues: An interdisciplinary review of the empirical evidence and theoreical accounts. Food Quality and Preference, 40, 165-179.

Perez, C., Tagliani, C., Arcia, P., Cozzano, S., Curutchet, A. (2018). Blueberry byproduct used as an ingredient in the development of functional cookies. Food Science and Technology International, 24(4), 301-308.

Reis, F., Alcaire, F., Deliza, R., Ares, G. (2017). The role of information on consumer sensory, hedonic and wellbeing perception of sugar-reduced products: Case study with orange/pomegranate juice. Food Quality and Preference, 62, 227236.

Research and Markets (2014). Global Functional Food and Nutraceuticals Market (2014 - 2020) - By Type (Foods, Beverages, Supplements); Benefits (Health and Wellness, Disease Prevention, Fitness, Beauty); Origin \& Ingredient.

Šarić, B., Mišan, A., Mandić, A., Nedeljković, N., Pojić, M., Pestorić M, Đilas, S. (2016). Valorisation of raspberry and blueberry pomace through the formulation of value-added gluten-free cookies. Journal of Food Science and Technology, 53(2), 1140-1150.

Scientific Advisory Committee on Nutrition (2014). Draft Carbohydrates and Health report. Scientific consultation: 26 June to 1 September 2014.

Stein, A.J., Rodríguez-Cerezo, E. (2008). Functional food in the European Union. Technical Report by the Joint Research Centre of the European Commission, EUR 23380 EN. Luxemburg: European Communities.

Torres, M., Tarrega, A., Torrescana, E., Blanch, C. (2012). Influence of label information on dark chocolate acceptability. Appetite, 58, 665-671. 
Tuorila, H. (2007). Sensory perception as a basis of food acceptance and consumption. In H. J. H. MacFie (Ed.), Consumer-led food product development. 34-59. Cambridge: Woodhead Publishing limited.

Tudoran, A., Olsen, S.O., Dopico, D.C. (2009). The effect of health benefit information on consumers health value, attitudes, and intentions. Appetite. 52(3), 568-79.

Urala, N., \& Lähteenmäki, L. (2007). Consumers' changing attitudes towards functional foods. Food Quality and Preference, 18, 1-12.

Van Raaij, J., Hendriksen, M., Verhagen, H. (2009). Potential for improvement of population diet through reformulation of commonly eaten foods. Public Health Nutrition, 12(3), 325-330.

Van Kleef, E., van Trijp, H., Luning, P., Jongen, W. M. (2002). Consumer-oriented functional food development: how well do functional disciplines reflect the 'voice of the consumer? Trends in Food Science \& Technology, 13(3), 93-101.

Van Kleef, E., van Trijp, H.C.M., Luning, P. (2005). Functional foods: health claim-food product compatibility and the impact of health claim framing on consumer evaluation. Appetite, 44, 299-308.

Varela, P., Ares, G., Gimenez, A., Gambaro, A. (2010). Influence of brand information on consumers' expectations and liking of powered drinks in central location tests. Food Quality and Preference, 21, 873-880.

Villegas, B., Carbonell, I., Costell, E. (2008). Effects of product information and consumer attitudes on responses to milk and soybean vanilla beverages. Journal of the Science of Food and Agriculture 88, 2426-2434.

Verbeke, W., Scholderer, J., Lähteenmäki, L. (2009). Consumer appeal of nutrition and health claims in three existing product concepts. Appetite, 52 (3), 684-692. 
Uso del subproducto de la producción de jugo de arándano como fuente de fibra 


\section{CAPÍTULO 3. Uso del subproducto de}

la producción de jugo de manzana como

fuente de fibra 


\title{
Consumers response to cake with apple pomace as a sustainable source of fibre
}

\author{
Ana Curutchet ${ }^{1}$, Julieta Trias ${ }^{1}$, Amparo Tárrega ${ }^{2}$ and Patricia Arcia $1,3, *$ \\ ${ }^{1}$ Área de Ciencia y Tecnología de Alimentos. Facultad de Ingeniería y Tecnologías UCU, Comandante \\ Braga 2715, CP 11600 Montevideo, Uruguay; ana.curutchet@ucu.edu.uy (A.C.); \\ ${ }^{2}$ Instituto de Agroquímica y Tecnología de Alimentos (IATA-CSIC), 46980 Paterna, Valencia, Spain; \\ ${ }^{3}$ Latitud Foundation LATU (Laboratorio Tecnológico del Uruguay), Av Italia 6201, 11500 Montevideo, \\ Uruguay.
}

Foods, (2021), 10(3), 1-12, 499. 


\begin{abstract}
The use of apple pomace flour (APF) as a fibre enrichment strategy was investigated. The aim of this study was to evaluate consumers response to intrinsic and extrinsic properties of a bakery- premix product when using APF. Apple pomace, by-product from the juice industry, was dried and ground. APF is high in carbohydrates (47.47\%) and fibre (38.48\%), it was used to partially substitute wheat flour and sugar in a cake premix. Acceptability, health and nutrition questions were evaluated with and without information in regular and fibre enriched cake. The regular cake scored was not affected by information, while the enriched cake's score increased with information. Three clusters were identified. Cluster 1 (29\%) showed high liking scores for regular cake, cluster 2 (31\%) for the fibre enriched one, and Cluster 3 (40\%) showed similar liking for both. Consumers described the samples and ideal cake using a Check-All-That-Apply (CATA) questionnaire. Penalty analysis explain differences in acceptability among consumers. Healthy, tasty and fibre content were the main reasons to buy the enriched cake for cluster 2 ; tasty for consumers in cluster 1 ; and healthy and tasty for consumers in cluster 3 . APF as a functional ingredient may be a consumers' choice as a sustainable use of apple pomace.
\end{abstract}

Keywords: by-product; cake premixes; acceptability; information. 


\section{INTRODUCTION}

Apples are one of the most popular fruits in the world and widely grown in all temperature regions. Worldwide, apple processing generates a huge volume of waste, considering the annual processed tonnage up to 11 million tons (Mt) [1]. Apple pomace is the pressed residue obtained after processing apples into juice, cider, distilled spirit and vinegar. The solid waste consists of the core, peel, seed, pulp and kernel of the fruit and represents 20$35 \%$ of the fresh weight of the apples [2]. According to the tonnage processed, 3.3 million tons (Mt) of waste are generated every year.

This by-product is usually treated in traditional ways, such as landfilling, incineration, composting and low-quality animal feed, causing serious environmental problems and losses for the industries, due to the waste treatment and transportation costs for dumping into landfills $[3,4]$. Thus, it is of vital importance to reuse industrial by-products to improve the process economics and its sustainability.

Apple pomace is an important source of dietary fibre, since nearly $40 \%$ of its dry weight is fibre [5]. According to [6], dietary fibre is a remnant of the edible part of plant; it is analogous carbohydrates that are resistant to digestion and absorption in the human small intestine and undergo complete or partial fermentation in the large intestine. Dietary fibre has many health benefits and could help in the treatment of obesity atherosclerosis, coronary heart diseases, large intestine cancer and diabetes by decreasing blood glucose level. It could bind hydrochloric acid, metal ions and cholesterol in the stomach and could also stimulate growth of probiotic microflora in the intestines [7]. An adequate intake for total dietary fibre is set at 28 and $25 \mathrm{~g}$ per day for young men and women, respectively [8].

Due to its relative low cost and potential nutritional value, apple pomace has been considered as an attractive functional ingredient to formulate human food. In fact, Alongui et al. [5] developed short dough biscuits with partial substitution of wheat flour by apple pomace flour which allows to reduce its glycemic index. Masoodi et al. [9] studied batter characteristics of cakes enriched with apple pomace and Rupasinghe et al. [10] evaluated the impact of baking in fibre and antioxidant capacity of muffins incorporated with different levels of apple skin powder.

However, the success in the market of a product including a new ingredient requires consumer's acceptance. Intrinsic product properties such as sensory properties are considered determining factors of acceptance and choice of a product but the extrinsic 
properties the information on the label such as brand, nutritional facts and claims can also play an important role in consumer buying behavior [11-15]. Previous studies have shown how characteristics related to the label can influence, positively or negatively, consumer expectation and hedonic evaluation of food products [16-21]. Concerning information about fibre content, its impact has been investigated for baguettes and roll breads by [20] and [21] respectively. The first one noticed that a "source of fibre" label in French baguettes had a positive effect on willingness to pay, while the second one observed that some consumers (clusters), even preferred bread with higher content of fibre. In the same way, [22] studied the effect of information about fibre in three types of muffins (plain, wholemeal and enriched with resistant starch), noticing that the score in texture and overall acceptance was increased in the muffin when nutritional information was provided. Many studies between 2017 to 2019 use apple pomace in bakery products. It has been studied the effect of apple pomace in nutritional profile, food color, texture properties. There are even some acceptability studies in cookies and gluten free crackers [23]. However, it has not been studied in depth how consumers perceive apple fibre.

As multiple elements could affect preference and liking, it is necessary to provide a view integrating as many factors as possible in product development, especially in the functional food one. Thus, the aim of the present work was to evaluate consumers response to intrinsic and extrinsic properties of a bakery- premix product when using apple pomace for fibre enrichment.

\section{MATERIALS AND METHODS}

\section{Apple pomace flour obtention}

Apple pomace was obtained as a by-product from juice production. The apples were Royal Gala, Early Red OneRed Chiff, Dana Red and Granny Smith harvested and processed in Uruguay, provided by MIS OLIVOS S.A (Montevideo, Uruguay). The apple pomace flour (APF) was obtained by drying apple pomace in a convection oven at $70^{\circ} \mathrm{C}$ for $8 \mathrm{~h}$ and grounding in a laboratory mill, using the fraction that passed through $1 \mathrm{~mm}$ sieve. APF was stored at $-18^{\circ} \mathrm{C}$ in a cold chamber.

\section{Apple pomace proximate composition}

Proximate analyses were performed on the apple pomace flour (APF). Protein was determined by the copper catalyst Kjeldahl method proposed by the Association of 
Official Analytical Collaboratrion (AOAC, 984.13) and Total dietary fibre (TDF) was determined using the AOAC enzymatic gravimetric method (985.29)[24]. Fat content was estimated using the Soxhlet procedure described by [25]. Moisture content was determined by gravimetric analysis in a convection oven at $105^{\circ} \mathrm{C}$ until constant weight. Ash was determined in a muffle furnace following [26]. Total carbohydrates content was obtained by difference, between the total weight and the sum of grams of protein, lipids, dietary fibre, moisture and ash content in $100 \mathrm{~g}$ of sample.

\section{Premix formulations and cakes preparation}

Apple pomace flour was used to prepare a pre-mix of fibre enriched cake. Developed premix-formulation included wheat flour, sugar, baking powder, skim milk powder and vanilla flavor (Table 1). The amount of Apple pomace (23.18 g per 100g) was adjusted to reach a fibre content of $6.3 \mathrm{~g} / 100 \mathrm{~g}$, with the aim of labeling the product with the claim "source of fibre", which corresponds to $2.5 \mathrm{~g}$ of dietary fibre per serving, according to the Uruguayan legislation [27].

Table 1. Formulated fibre enriched cake premix composition.

\begin{tabular}{lcc}
\hline Ingredients & Amount in premix (\%) & Amount in the cake (\%) \\
\hline Wheat flour & 35.67 & 20.55 \\
Apple pomace flour & 23.18 & 13.36 \\
Sugar & 31.21 & 17.98 \\
Baking powder & 4.46 & 2.57 \\
Skim milk powder & 3.57 & 2.05 \\
Vanilla flavor & 1.92 & 1.10 \\
Vegetable oil & - & 7.71 \\
Eggs & - & 12.84 \\
Water & - & 21.83 \\
\hline
\end{tabular}

A regular cake was prepared using a commercial pre-mix brand (sugar, wheat flour, corn starch, whey protein, glucose syrup, baking powder, vanilla flavor, carboxymethylcellulose, content non-declared) with the highest acceptably among cake premixes in Uruguayan market [28].

Cakes were prepared with the premix and adding vegetable oil, eggs and water, following the proportions established in Table 1. Nutrition facts for both cakes were calculated (Table 2). Ingredients were obtained from the local market. 
Table 2. Nutrition facts for fibre enriched and regular cake expressed as content in $100 \mathrm{~g}$ of sample.

\begin{tabular}{lcc}
\hline Ingredients & Fibre enriched cake & Regular cake \\
\hline Energy & $275 \mathrm{kcal}=1149 \mathrm{~kJ}$ & $332 \mathrm{kcal}=1388 \mathrm{~kJ}$ \\
Carbohydrate & $43 \mathrm{~g}$ & $52 \mathrm{~g}$ \\
Protein & $4.8 \mathrm{~g}$ & $11 \mathrm{~g}$ \\
Total fat & 9.5 & $8.7 \mathrm{~g}$ \\
from which saturated & $1.1 \mathrm{~g}$ & $3.2 \mathrm{~g}$ \\
Dietary fibre & $6.3 \mathrm{~g}$ & $1.0 \mathrm{~g}$ \\
Sodium & $280 \mathrm{mg}$ & $448 \mathrm{~g}$ \\
\hline
\end{tabular}

\section{Cake labels}

The packaging of both cakes was designed using as reference the label of the commercial cake premix that is a brand leader in the Uruguayan market. The original packaging was adjusted in such a way, that the only difference between both products were nutritional facts (Table 2), claims and cake aesthetic. The claim "source of fibre" was included as well as the "with apple fibre" reference in the fibre enriched cake. The labels of both cakes are shown in Figure 1.
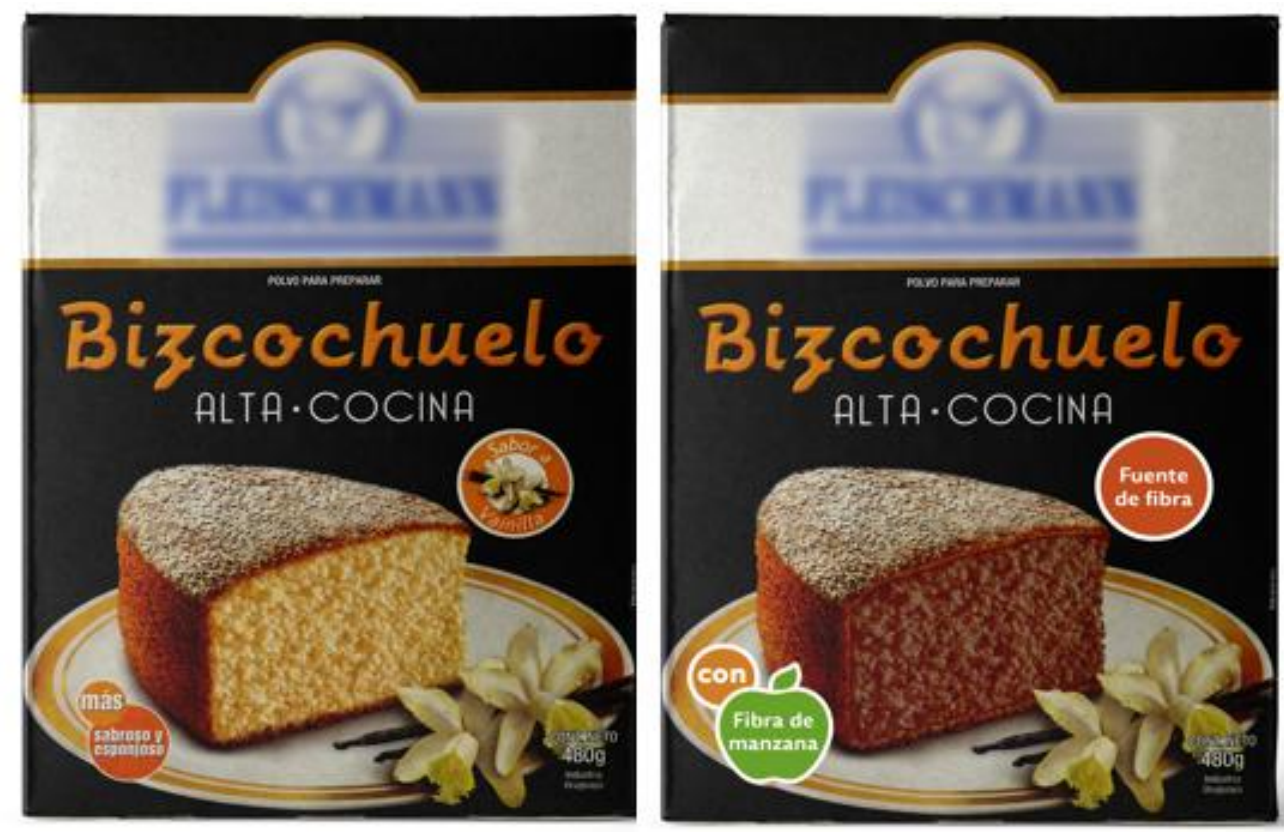

Figure 1. Product packaging design.

\section{Consumer evaluation sessions}

Two consumer sessions were developed with the fibre enriched cake and regular cake, blind and informed test. In both evaluation samples were served to consumers on plastic plates, coded using random three-digit numbers. Water was available for consumers. 


\section{Blind test}

In these acceptability test, consumers evaluate the product without any information. The session was carried out by 104 consumers (58\% men and $42 \%$ women) whose ages ranged between 17 and 60 years old. Overall acceptability was evaluated with a nine-point hedonic scale, ranging from 1 ("I dislike extremely") to 9 ("I like extremely).

\section{Informed test}

A second evaluation including product packages was performed to evaluate the impact of information on the response of consumers (acceptability and purchase intention).

A total of 102 consumers, whose ages ranged between 18 and 70 years old evaluated the cakes with the label information presented as an image on a computer screen. For each sample, consumer was asked to observe the label, taste the sample and then, rate acceptability in a nine-point scale, ranging from 1 ("I dislike extremely") to 9 ("I like extremely") and purchase intention in a 5-point scale from "I would definitely buy it" to "I would definitely not buy it". After that, a CATA questionnaire was used to describe the sample. The list of attributes in the CATA questionnaire was determined in a preliminary essay with 10 consumers and included sensory and non-sensory characteristics: (homemade, flattened, tasty, aftertaste, high in calories, dry, moist, distasteful, gritty, soft, intense flavor, tasteless, fruity flavor, healthy, sweet, spongy, easy to chew, bitter, fibrous, odd flavor, hard to chew).

According to the response to the purchase intention, consumers were asked to indicate the reasons for either buying or not buying the cake, by selecting the appropriate ones from a list previously generated in a preliminary assay with 10 consumers (Table 3 ).

Consumers were also asked their frequency of consumption of cakes, in a four-point scale from 1 ("never") to 4 ("once a week or more"), After that, participants completed the General Health Interest questionnaire proposed by Roininen et al. [29] using the Spanish version reported by Villegas et al., [30]. Finally, respondents completed some demographic questions, gender and age. Data collection were conducted using Compusense Cloud (Compusense Inc., Guelph, ON, Canada). 
Table 3. Question of purchase intention: reasons for buying or not buying the cake.

\section{Why would you buy it?}

1. Because it is healthy

2. Because it is tasty

3. Because it is the one I always buy

4. Because I don't need fibre in my diet

5. Because it is low in calories

6. To avoid weight gain

7. Because it is good for my kids

8. Because I want to include fibre in my diet

9. Because my kids would like it.

\section{Why wouldn't you buy it?}

1. Because it is not healthy

2. Because it is distasteful

3. Because it is not the one I always buy

4. Because I need fibre in my diet

5. Because it is calorific

6. To prevent weight gain

7. Because it is bad for my kids

8. Because I don't want to include fibre in my diet

9. Because my kids wouldn’t like it.

\section{Data analysis}

All the results are expressed as mean \pm SD. A t-Student test was performed to compare overall acceptability and purchase intention of samples. To identify groups of consumers with different patterns, hierarchical cluster analysis considering Euclidean distances and Ward's aggregation method were applied. Composition of each cluster according to consumer gender, age and interest in a healthy diet were compared using the Chi-square test. Significant differences among proportions were determined using Marascuilo procedure [31]. A non-parametric, Mann-Whitney test was performed to compare acceptability between samples into clusters.

The frequency of mention of each CATA term was determined. The Cochran's Q test was performed on the binary CATA data to determine significant differences between samples for each attribute $(p \leq 0.05)$. To determine the impact of each attribute on liking, penalty- 
lift-analysis was used. For that, liking is averaged across all observations (consumers) in which the attribute was used to describe the product, and across those observations for which it was not used. The difference between these two mean values provides an estimate of the average change in acceptability due to the presence of the attribute. The same procedure was replicated in each sample (regular and fibre enriched cake).

Analyses were performed using XLSTAT 2020.3.1 (Addinsoft 2020, New York, NY, USA).

\section{RESULTS AND DISCUSSION}

\section{Apple pomace flour characteristics as an ingredient}

Proximate composition of the APF, including the contents for protein, fat, ash, dietary fibre and carbohydrates content is shown in Table 4. As notable features, APF includes high contents of dietary fibre and carbohydrates from fruit and low-fat content. According to that, APF is an interesting ingredient to substitute part of the wheat flour in sweet bakeries. It allows incorporating fibre to reduce sucrose content. In the same way [32] used APF as an ingredient with high levels of polyphenols and also phytate-free dietary fibre to develop gluten free cakes. [23] developed a systematic review of apple pomace as a food fortification ingredient. They conclude analyzing data from 2007-2019 that APF has a beneficial nutritional profile and it is an ecological issue.

For the above-mentioned reasons, it was decided to use apple pomace as a functional ingredient in the development of a bakery pre-mixes, evaluating its acceptability and the effect of information on consumer's response in comparison with commercial pre-mixes.

Table 4. Proximate composition of the apple pomace $\mathrm{g} / 100 \mathrm{~g}$.

\begin{tabular}{cc}
\hline Proteins & $3.04 \pm 0.18$ \\
Lipids & $3.08 \pm 0.08$ \\
Ash & $2.07 \pm 0.10$ \\
Dietary fibre & $38.48 \pm 0.20$ \\
Carbohydrates & $47.47^{1}$ \\
\hline
\end{tabular}

${ }^{1}$ Carbohydrate content was obtained by difference. 


\section{Acceptability of cakes in blind and informed condition}

Means of acceptability for the regular and fibre enriched cakes in blind and informed conditions are shown in Table 5. In blind condition, when consumers only tasted samples, mean of liking scores for the fibre enriched cake was significantly lower than for the regular cake. This difference in liking may be due not only to the presence of fibre but also to the fact that regular cake was higher in fat and sugar contents, which are usually related to higher overall acceptability [33]. The amount of added sugar was kept lower than in regular cake because it was expected a contribution of apple pomace to sweetness due to its high sugar content and trying to develop a healthier product.

Table 5. Acceptability of cakes under blind and informed conditions and purchase intention.

\begin{tabular}{lccc}
\hline \multicolumn{1}{c}{ Product } & Blind Condition & Informed Condition & Intention to Purchase \\
\hline Fibre enriched cake & $5.34 \pm 1.80^{\mathrm{a}, \mathrm{A}}$ & $6.55 \pm 1.58^{\mathrm{a},}$ & $3.42 \pm 1.02^{\mathrm{a}}$ \\
\hline Regular cake & $6.70 \pm 1.74^{\mathrm{b}, \mathrm{A}}$ & $7.06 \pm 1.50^{\mathrm{b}, \mathrm{A}}$ & $3.69 \pm 0.99^{\mathrm{b}}$ \\
\hline
\end{tabular}

For the same column, scores not sharing letters are significantly different $(p \leq 0.05)$ according to the t-student test. For the same row, scores not sharing capital letters row are significantly different $(p \leq 0.05)$ according to the t-student test.

By comparing blind and informed conditions, label presence showed to significantly increase consumers liking for the fibre enriched cake while for the regular cake, label presence only caused a slight increase in acceptability that was not significant. This indicates claims "fibre source" and "apple fibre" increased acceptability for cake. According to [34], product information may influence consumer's expectation and choice. They found a positive effect of nutritional information on consumer's acceptability of pasta produced with the addition of wheat bran and similar results were obtained by [22] who observed that overall acceptability increased when information was provided for a whole meal muffin.

Despite the increase observed for fibre enriched cake, it showed a lower liking score than the regular cake. However, the percentage of consumers buying fibre enriched cake (53\%) was close to the observed for the regular one (63\%). 


\section{Individual variability in consumers response to apple fibre enriched cake}

Cluster analysis was applied to identify segments of consumers with different patterns of preference respect the regular and fibre enriched cakes (evaluated in presence of the label). Three clusters were identified (Table 6). Consumers in Cluster 1 (29\%) showed high liking scores for regular cake and low liking scores for the fibre enriched cake. Only $13 \%$ of them would buy fibre enriched cake and $56 \%$ would buy the regular cake. Cluster $2(31 \%)$ prefered fibre enriched cake than regular cake. The $81 \%$ of these consumers would buy the fibre enriched cake and the $41 \%$ would buy the regular. Finally, Cluster 3 (40\%) despite showing high liking scores for both cakes, liked more the regular one. Thus, while a high percentage of consumers would buy the regular cake, many of them would also buy the fibre enriched one (59\%).

Table 6. Clusters composition according cake acceptability, cakes' frequency consumption and consumer's age distribution.

\begin{tabular}{lccc}
\hline \multicolumn{1}{c}{ Product } & Cluster 1 (29\%) & Cluster 2(31\%) & Cluster 3 (40\%) \\
\hline Apple fibre cake & $4.5^{\mathrm{a}}$ & $7.4^{\mathrm{a}}$ & $7.3^{\mathrm{a}}$ \\
Regular cake & $6.5^{\mathrm{b}}$ & $5.9^{\mathrm{b}}$ & $8.3^{\mathrm{b}}$ \\
Age (> 35years) * & $35^{\mathrm{A}}$ & $58^{\mathrm{B}}$ & $39^{\mathrm{AB}}$ \\
\hline
\end{tabular}

Mean acceptability scores of consumers (Clusters 1-3). Scores not sharing letters within each cluster were significantly different $(\mathrm{p} \leq 0.05)$ according to Mann-Whitney test.

*Scores not sharing capital letters are significantly different $(\mathrm{p} \leq 0.05)$ according to the Chi-square test. Significant differences among proportions were determined using Marascuilo procedure.

Previous studies have shown that inter-individual differences are especially relevant in the response of consumers to fibre related information and claims in products like bread, muffins, yogurt and cakes [22,35,36]. In the same way, [35] and [36] found culturerelated differences in the impact of fibre information on liking and/or sensory properties of food and [22] found that fibre-related information was more effective in increasing liking of muffins for health-conscious consumers.In the present study, clusters did not significantly differ in gender $(p=0.360)$ and health interest $(p=0.861)$ but they differed in age $(p=0.019)$. Cluster 1 and 3 were mainly composed by people younger than 35 (66\% and 61\%) and cluster 2 showed more people older than $35(58 \%)$. It seems that in the case of fibre old people show more willingness to accept a new product than young people. Similarly, [20] found a significant age effect on the willingness to pay for highfibre bread. According to these authors, young consumers are more influenced than the older ones by the hedonic value of the bread more than health concerns and they are not scarifying pleasure for health. 


\section{Consumer's drivers of liking and reasons to purchase}

Consumers also described (CATA questionnaire) the cakes after tasting them and observing the labels. For 15 of the 21 terms in the list significant differences were observed in the frequency of mention. Figure 2 shows the frequency of mention of the two cakes compared to the ideal cake, which was described by most of the participants as homemade, tasty, moist, sweet, soft, spongy, and healthy. The fibre enriched cake showed a higher frequency for some of these terms, like homemade and healthy while the regular cake showed higher frequency of sweet and soft. Both cakes were described as tasty and easy to chew. Among the terms not cited for the ideal cake, dry and tasteless was used similarly for both cakes by some few consumers (15-18\%) and fibrous and sandy were used by some consumers only for the fibre enriched cake.

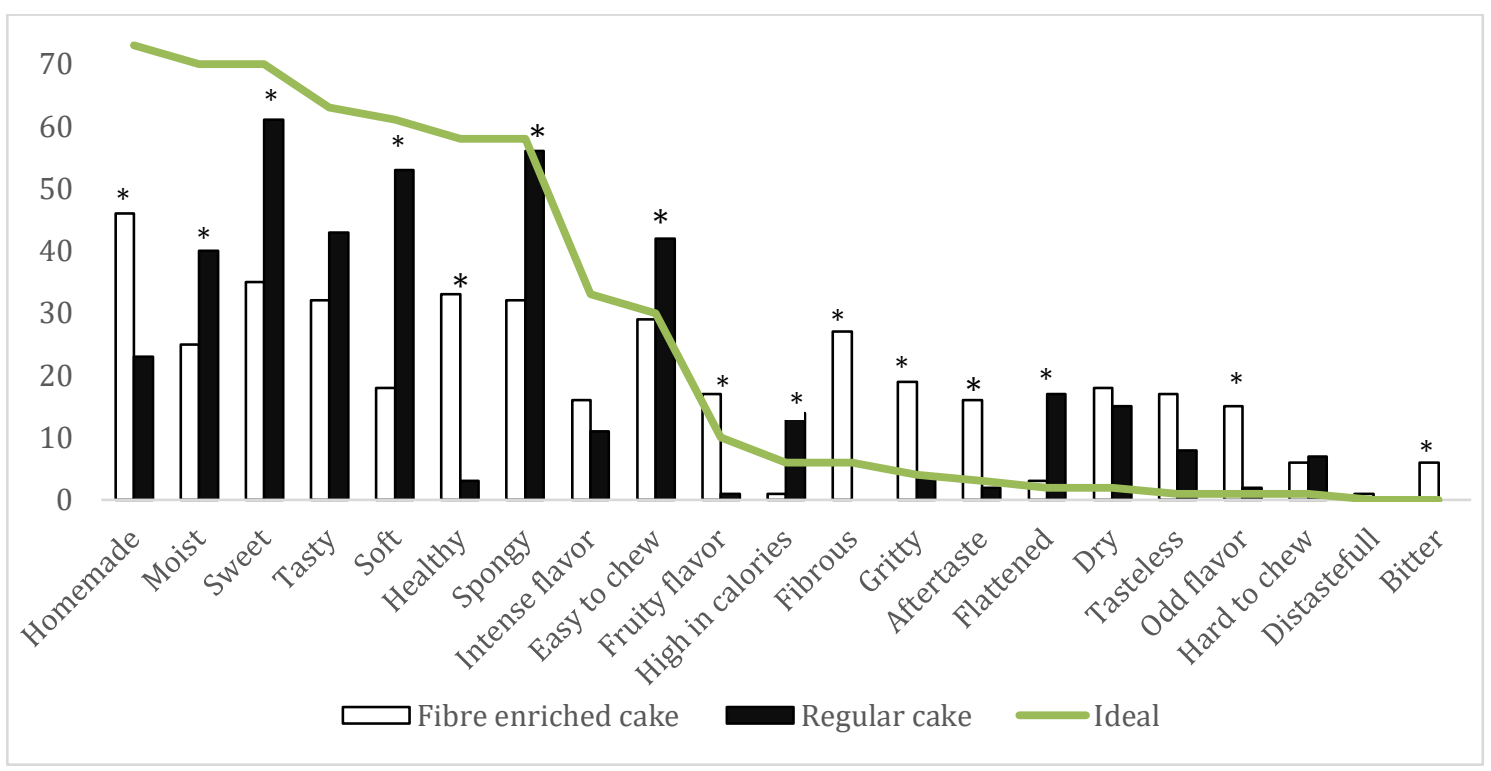

Figure 2. Frequency of CATA terms for the fibre enriched, regular and ideal cake.

* CATA terms with have significant differences between regular cake and fibre enriched cake $p<0.05$.

To understand the variability in consumers response, a penalty lift analysis was applied to determine the attributes that explain the differences in consumers liking scores for the same product (Figure 3). For the fibre enriched cake, the acceptability was higher for consumers that described it as tasty, homemade and healthy, and lower for consumers that found it tasteless or dry. For the regular cake, the variation in liking scores among consumers was mainly associated to positive terms; the consumers who found the cake 
tasty, homemade, easy to chew, soft, and spongy gave it a higher liking score while those who found the cake dry gave it a lower liking score (Figure 3).

a)

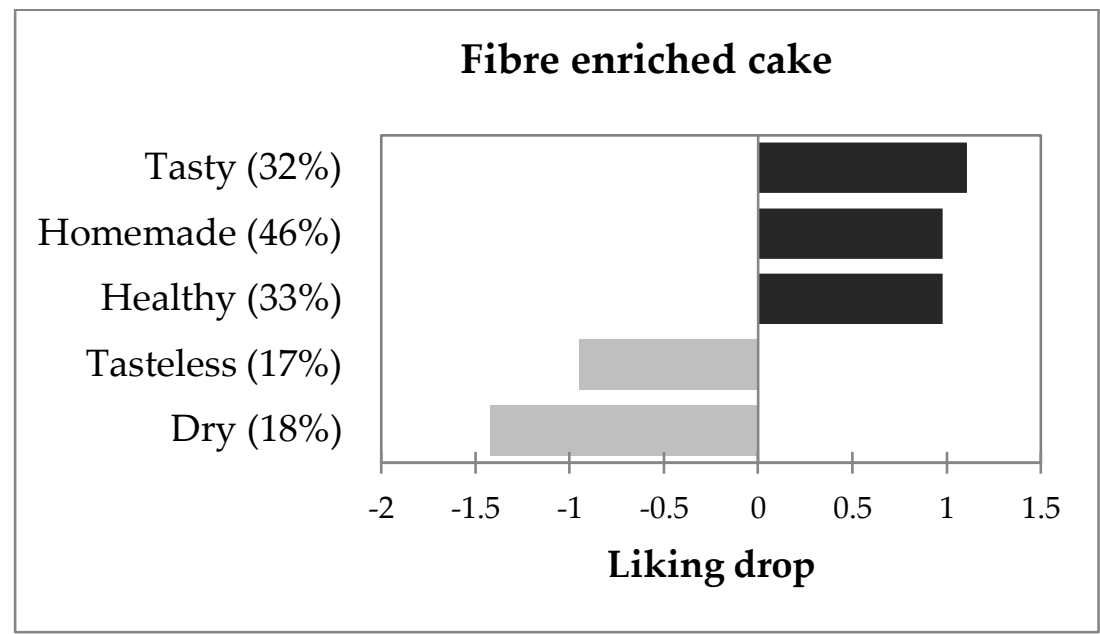

b)

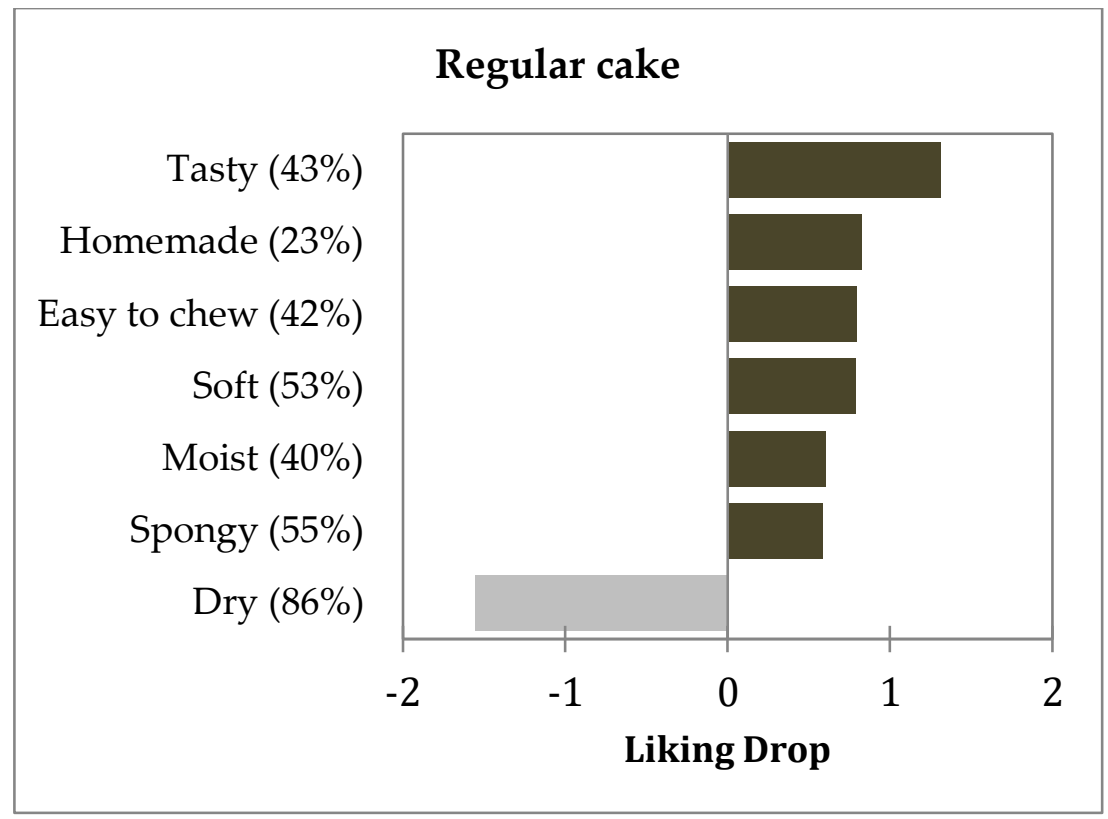

Figure 3. Impact of the attributes on the acceptability of the regular b) and the fibre enriched a) cakes according to Penalty lift analysis. For each attribute, the percentage of consumers that selected it for describing the product is indicated in brackets.

Figure 3 shows as global results that most attributes have a positive connotation in cakes. As expected, the attributes tasty, soft, homemade, easy to chew and moist are found to be the most important drivers of liking, increase liking by around 1 point on the 9-point scale when they are present. On the other hand, the worst impact in acceptability is given by the attributes flattened, distasteful, and bitterly. 
In sponge cakes enriched with fibre from different sources, [37] reported a similar positive impact of easy to chew, spongy, soft and sweet on liking. Negative impact of dry and tasteless sensations on liking was also found by these authors, but they also found negative impact of soft, odd flavor and fruity flavor (specially for blackcurrant fibre cake) that has not been found in this work, for the cake enriched with apple fibre. This seems to be an advantage of apple fibre because as reported by [38], certain flavors provided by the addition of fruit fibre can make the product too different from original to be acceptable. It is important to note that while in this work, homemade and healthy were relevant attributes with positive impact for the fibre enriched cake, they were not found to be relevant in the study of [37]; one possible explanation for this difference is that in this study cakes were evaluated without any product information.

As expected, the reasons consumers linked to the buying decision are in agreement with the drivers of linking. Among consumer buying the fibre enriched cake (53\%), the main reasons were healthy (27\%) and tasty (35\%) (Figure 4). As observed in Figure 4, being healthy and tasty were relevant reasons for consumers in cluster 2, but for consumers in cluster 3 being tasty was more relevant. Among those buying regular cake $(67 \%$ of consumers), being tasty was the reason indicated for almost all of them (60\% of consumers). For both, fibre enriched and regular cake, the main reasons for not buying the cake were that it was not tasty (23\% and $11 \%$ respectively) but also to prevent weight gain (8\%). Additionally, some consumers did not buy fibre enriched cake because it was not the same as always, and some consumers did not buy regular cake because they consider it not healthy.

In the same way, [39] studied fibre enriched breads and found two groups of consumers with different consumption choices. Hedonistic consumers whose motives were driven mainly by "mood" and "price" and traditional consumers driven by "natural content", "familiarity" and "health concern" claims.

Regarding reasons to buy, [40] found that price, sensory appeal, convenience, and health were strong motives contributing to food choices. These authors also report that young adults who value the food choice motives of weight control and natural content are likely to have a very positive attitude towards functional food. As [41] proposed that young adults experience many barriers to living a healthy lifestyle, high stress, poor sleep and challenges in time balance, that may increase the need for convenience in food choices. APF was used as a fibre enrichment strategy, as figure 1 shows, consumers can notice that the products contains apple fibre, but they do not have information about apple fibre 
origin. Consumers do not have explicit information about fibre enriched cake sustainability. Kaczorowska et al., 2019 [42] found that sustainability labels influence consumer buying behaviour in spite of the fact that consumers perceive the benefits of buying them differently. In these way it should be explore if sustainability should be a valuable reason to rise up the lower acceptability of fibre enriched cake.

a)

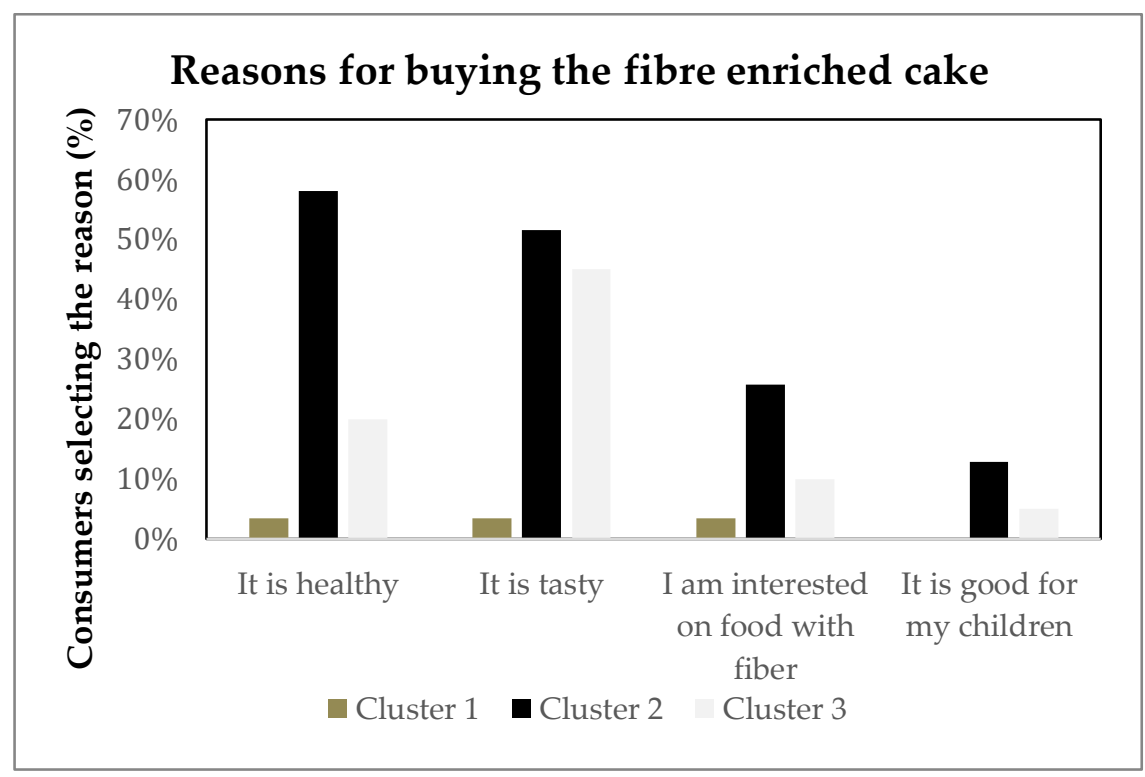

b)

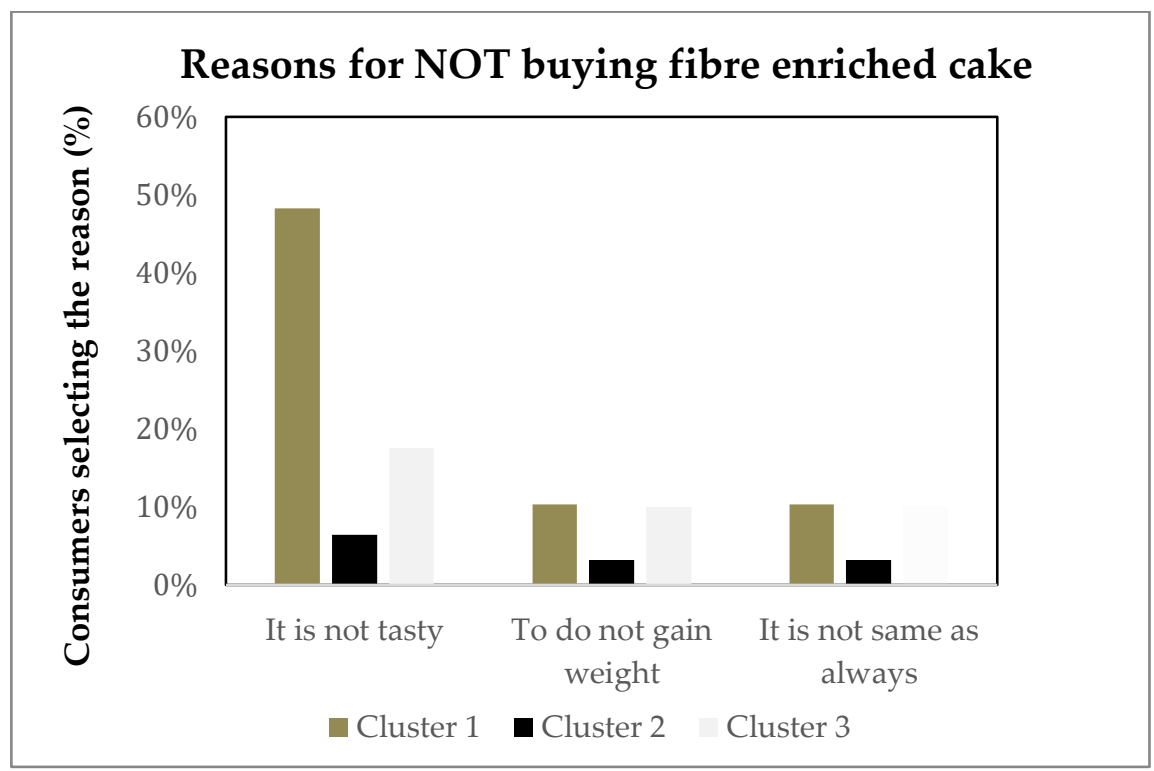

Figure 4. Reasons to buy (a) or not (b) cakes evaluated with information between three clusters. Reasons selected for more than $10 \%$ of consumers are included. 


\section{CONCLUSIONS}

Due to its high fibre content, apple pomace flour, obtained by mild processing conditions, shows a high potential as ingredient to produce bakery goods with healthier formulation. The cake enriched with apple pomace flour was lest liked by consumers than a regular cake but liking showed to increase when having the product packaging with "fibre source" and "apple fibre" claims and nutritional fact. High individual variability in consumer's response to fibre enriched and regular cakes was observed. Clustering consumer's response allowed to identify a group (30\% of participants) that preferred fibre enriched cake over regular one because they considered it was healthy, tasty, like homemade and provided fibre they needed in the diet. Among consumers preferring regular cake, some of them were also interested on the fibre enriched cake, and mainly because they liked as well. Despite young people are usually more willing to accept new products, in this case, consumers not interested on buying fibre enriched cake were mainly young people $(<35$ years old) and the main reason was that they did not like sample. Improving sensory characteristics such as increasing sweetness, moist, sponginess and softness sensation may be a way to increase success of the product.

Apple pomace flour may have a place among consumers. This may be a promissory use of apple pomace. The large amount of waste generated by this by-product makes finding alternative uses a priority.

\section{AUTHOR CONTRIBUTIONS}

Conceptualization, A.C. and P. A.; methodology, A. C., P.A. and J.T.; validation, A.C., P. A. and A.T.; formal analysis, A. C. and A. T..; writing - original draft preparation, A. C. and J.T.; writing-review and editing, A. C., P.A. and A. T.; supervision, P.A. and A.T. All authors have read and agreed to the published version of the manuscript."

\section{ACKNOWLEDGMENTS}

The authors thank Natural tree for providing the raw material. 


\section{CONFLICTS OF INTEREST}

The authors declare no conflict of interest.

\section{REFERENCES}

1. USDA. Fresh Delicious Fruit: World Markets and Trade (Apples, Grapes \& Pears); Foreign Agricultural Service: Washington DC, USA, 2018; 1-30.

2. Rabetafika, H.N.; Bchir, B.; Blecker, C.; Richel, A. Fractionation of apple byproducts as source of new ingredients: Current situation and perspectives. Trends Food Sci. Technol. 2014, 40, 99-114, doi:10.1016/j.tifs.2014.08.004.

3. Dhillon, G.S.; Kaur, S.; Kaur Brar, S. Perspective of apple processing wastes as lowcost substrates for bioproduction of high value products: A review. Renew. Sustain. Energy Rev. 2013, 27, 789-805, doi:10.1016/j.rser.2013.06.046.

4. Macagnan, F.T.; Rodrigues dos Santos, L.; Sampaio, R.B.; Aline de Moura, F.; Bizzani, M.M.; Picolli da Silva, L. Biological properties of apple pomace, orange bagasse and passion fruit peel as alternative sources of dietary fibre. Bioact. Carbohydr. Diet. Fibre 2015, 6, 1-6, doi:10.1016/j.bcdf.2015.04.001.

5. Alongui, M.; Melchior, S.; Anese, M. Reducing the glycemic index of short dough biscuits by using apple pomace as a functional ingredient. LWT 2019, 100, 300-305, doi:10.1016/j.lwt.2018.10.068.

6. American Association of Cereal Chemists-AACC. The definition of dietary fibre. Cereal Foods World 2001, 46, 112-126.

7. Kruczeck, M.; Gumul, D.; Kacaniova, M.; Ivanishova, E.; Marecek, J.; Gambus, H. Industrial apple pomace by-products as a potential source of pro-health compounds in functional food. JMBFS 2017, 7, 22-26, doi:10.15414/jmbfs.2017.7.1.22-26.

8. USDA. The Food Supply and Dietary Fibre: Its Availability and Effect on Health, Nutrition Insight 36; USDA Center for Nutrition Policy and Promotion: Washington, DC, USA, 2007.

9. Masoodi, F.; Sharma, B.; Chauhan, G. Use of apple pomace as a source of dietary fibre in cakes. Plant Foods Hum. Nutr. 2002, 57, 121-128, doi:10.1023/A:1015264032164. 
10. Rupasinghe, H.P.V.; Wang, L.; Huber, G.M.; Pitts, N.L. Effect of baking on dietary fibre and phenolics of muffins incorporated with apple skin powder. Food Chem. 2008, 107, 1217-1224, doi:10.1016/j.foodchem.2007.09.057.

11. Ares,G.; Deliza,R. Studying the Influence of Package Shape and Colour on Consumer Expectations of Milk Desserts Using Word Association and Conjoint Analysis. Food Qual. Pref. 2010, 2, 930-937, doi:10.1016/j.foodqual.2010.03.006.

12. Carrillo, E.; Varela, P.; Fiszman, S. Effects of food package information and sensory characteristics on the perception of healthiness and the acceptability of enriched biscuits. Food Res. Int. 2012, 48, 209-216, doi:10.1016/j.foodres.2012.03.016.

13. Chrea, C.; Melo, L.; Evans, G.; Forde, C.; Delahunty, C.; Cox, D.N. An investigation using three approaches to understand the influence of extrinsic product cues on consumer behavior: An example of Australian wines. J. Sens. Stud. 2011, 26, 13-24, doi:10.1111/j.1745-459X.2010.00316.x.

14. Deliza, R.; MacFie, H. The Generation of Sensory Expectation by External Cues and Its Effect on Sensory Perception and Hedonic Ratings: A Review. J. Sens. Stud. 1996, 11, 103-128, doi:10.1111/j.1745-459X.1996.tb00036.x.

15. Reis, F.; Alcaire, F.; Deliza, R.; Ares, G. The role of information on consumer sensory, hedonic and wellbeing perception of sugar-reduced products: Case study with orange/pomegranate juice. Food Qual. Pref. 2017, 62, 227-236, doi:10.1016/j.foodqual.2017.06.005.

16. Grunert,K.G. Current issues in the understanding of consumer food choice. Trends Food Sci. Technol. 2002, 13, 275-285, doi:10.1016/S0924-2244(02)00137-1.

17. Deliza, R.; MacFie, H.; Hedderley, A. Consumer attitude towards information on non conventional technology. Trends Food Sci. Technol. 2003, 14, 43-49, doi:10.1016/S0924-2244(02)00240-6.

18. Costell, E.; Tárrega, A.; Bayarri, S. Food Acceptance: The Role of Consumer Perception and Attitudes. Chem. Percept. 2010, 3, 42-50, doi:10.1007/s12078-0099057-1.

19. Mueller, S.; Szolnoki, G. The relative influence of packaging, labelling, branding and sensory attributes on liking and purchase intent: Consumers differ in their responsiveness. Food Qual. Pref. 2010, 21, 774-783, doi:10.1016/j.foodqual.2010.07.011. 
20. Ginon, E.; Lohéac, Y.; Martin, C.; Combris, P.; Issanchou, S. Effect of fibre information on consumer willingness to pay for French baguettes. Food Qual. Pref. 2009, 20, 343-352, doi:10.1016/j.foodqual.2009.01.002.

21. Gebsky, J.; Jesewska-Zychowicz, M.; Szlanchciuk, J.; Kosicka-Gebska, M. Impact of nutritional claims on consumer preferences for bread with varied fibre and salt content. Food Qual. Pref. 2019, 76, 91-99, doi:10.1016/j.foodqual.2019.03.012.

22. Baixauli, R.; Salvador, A.; Hough, G.; Fiszman, S.M. How information about fibre (traditional and resistant starch) influences consumer acceptance of muffins. Food Qual. and Pref. 2008, 19, 628-635, doi:10.1016/j.foodqual.2008.05.002.

23. Antonic, B.; Jancikova, S.; Dordevic, D.; Tremlova, B. Apple pomace as food fortification ingredient: A systematic review and meta-analysis. J. Food Sci. 2020, 85, 2977-2985, doi:10.1111/1750-3841.15449.

24. AOAC. Official Methods of Analysis of AOAC International, 19th ed; AOAC International: Gaithersburg, MD, USA, 2012.

25. ISO-6492-1999. International Organization for Standardization, Animal Feeding Stuffs—Determination of Fat Content; ISO: Geneva, Switzerland, 1999.

26. ISO-5984-2002. International Organization for Standardization, Animal Feeding Stuffs-Determination of Crude Ash; ISO: Geneva, Switzerland, 2002.

27. Reglamento Técnico MERCOSUR sobre Información Nutricional Complementaria (Declaraciones de Propiedades Nutricionales). MERCOSUR/GMC/RES. N01/12. http://www.puntofocal.gov.ar/notific_otros_miembros/pry33a1_t.pdf (01 august 2019.

28. Trías, J.; Curutchet, A.; Arcia Cabrera, P.; Cozzano, S. Revalorización del descarte originado por la producción de jugo de manzana como ingrediente funcional en la formulación de premezclas para horneados. INNOTEC 2021, 21, 52-67, doi:/10.26461/21.04.

29. Roininen, K.; Lähteenmäki, L.; Tuorila, H. Quantification of Consumer Attitudes to Health and Hedonic Characteristics of Foods. Appetite 1999, 33, 71-88, doi:10.1006/appe.1999.0232.

30. Villegas, B.; Carbonell, I.; Costell, E. Effects of product information and consumer attitudes on responses to milk and soybean vanilla beverages. J. Sci. Food Agric. 2008, 88, 2426-2434, doi:10.1002/jsfa.3347.

31. Levy, K.J. Large-sample pair-wise comparisons involving correlations, proportions, or variances. Psychol. Bull. 1975, 82, 174-176, doi:10.1037/h0076377. 
32. Azari, M.; Shojaee-Aliabadi, S.; Hosseini, H.; Mirmoghtadaie, L.; Marzieh Hosseini, S. Optimization of physical properties of new gluten-free cake based on apple pomace powder using starch and xanthan gum. Food Sci. Technol. Int. 2020, 26, 603-613, doi:10.1177/1082013220918709.

33. Biguzzi, C.; Schlich, P.; Lange, C. The impact of sugar and fat reduction on perception and liking of biscuits Food Qual. Pref. 2014, 35, 41-47, doi:ff10.1016/j.foodqual.2014.02.001f.

34. Laureati, M.; Conte, A.; Padalino, L.; Alessandro del Nobile, M.; Pagliarini, E. Effect of fibre information on consumer's expectation and liking of wheat bran enriched pasta. J. Sens. Stud. 2016, 31, 348-359.

35. Mialon, V.S.; Clark, M.R.; Leppard, P.I.; Cox, D.N. The effect of dietary fibre information on consumer responses to breads and "English" muffins: A crosscultural study. Food Qual. Prefer. 2002, 13, 1-12, doi:10.1016/S09503293(01)00051-9.

36. Saba, A.; Vassallo, M.; Shepherd, R.; Lampila, P.; Arvola, A.; Dean; Winkelmann, M.; Claupein, E.; Lähteenmäki, L. Country-wise differences in perception of healthrelated messages in cereal-based food products. Food Qual. Prefer 2010, 21, 385393, doi:10.1016/j.foodqual.2009.09.007.

37. Tarrega, A.; Quiles, A.; Morell, P.; Fiszman, S.; Hernando, I. Importance of consumer perceptions in fibre/enriched food products. A case study with sponge cakes. Food Function 2016, 8, 574-583, doi:10.1039/C6FO01022A.

38. Koskinen, S.; Kälviäinen,N.; Tuorila, H. Perception of chemosensory stimuli and related responses to flavored yogurts in the young and elderly. Food Qual. Prefer 2003, 14, 623-635./10.1016/S0950-3293(02)00187-8.

39. Pohjanheimo, T.; Paasovaara, R.; Luomala,H.; Sandell, M. Food choice motives and bread liking of consumers embracing hedonistic and traditional values. Appetite 2010 54, 170-180, doi:10.1016/j.appet.2009.10.004.

40. Vorage, L.; Wiseman, N.; Graca, J.; Harris, N. The Association of Demographic characteristics and food choice motives with the consumption of functional foods in emerging adults. Nutrients 2020, 12, 2582, 1-14, doi:10.3390/nu12092582.

41. Nelson, M.; Story, M.; Larson, N. Emerging adulthood and college-aged youth: An overlooked age for weight-related behavior change. Obesity 2008, 16, 2205-2211, doi:10.1038/oby.2008.365. 
42. Kaczorowska,J.; Rejman, K.; Halicka,E.; Szczebylo, A.; Gorska-Warsewicz, H. Impact of food sustainability labels on the perceived product value and price expectations of urban consumers. Sustainability 2019, 11, 7240. 
Uso del subproducto de la producción de jugo de manzana como fuente de fibra 


\section{CAPÍTULO 4. Uso del subproducto de \\ la producción de cerveza como fuente de}

fibra 


\title{
Sensory features introduced by brewery spent grain with impact on consumer motivations and emotions for fibre enriched products
}

\author{
Ana Curutchet ${ }^{1}$, Maite Serantes ${ }^{1}$, Carolina Pontet ${ }^{1}$, Fátima Prisco ${ }^{1}$, Gabriel Barg ${ }^{3}$, Juan \\ Andres Menendez ${ }^{3}$, Amparo Tarrega ${ }^{4}$, Patricia Arcia ${ }^{1,2}$ \\ ${ }^{1}$ Engineering department, Catholic University of Uruguay, Montevideo, Uruguay \\ ${ }^{2}$ Latitud - LATU Foundation, Montevideo, Uruguay \\ ${ }^{3}$ Neuroscience and learning department, Catholic University of Uruguay, Montevideo, Uruguay \\ ${ }^{4}$ Physical and Sensory Properties Laboratory. Instituto de Agroquímica y Tecnología de Alimentos \\ Agrochemistry and Food Technology Institute, CSIC. Avda. Ave. Agustín Escardino, 7 (46980) Paterna \\ (Valencia) Spain
}

Enviado : a Foods 


\section{HIGHLIGHTS}

- BSG as a functional ingredient by formulating food products with the Source of Fibre claim.

- Effect of BSG on the sensory perception is product specific.

- Fibre enrichment impacts on emotions.

\section{GRAPHICAL ABSTRACT}

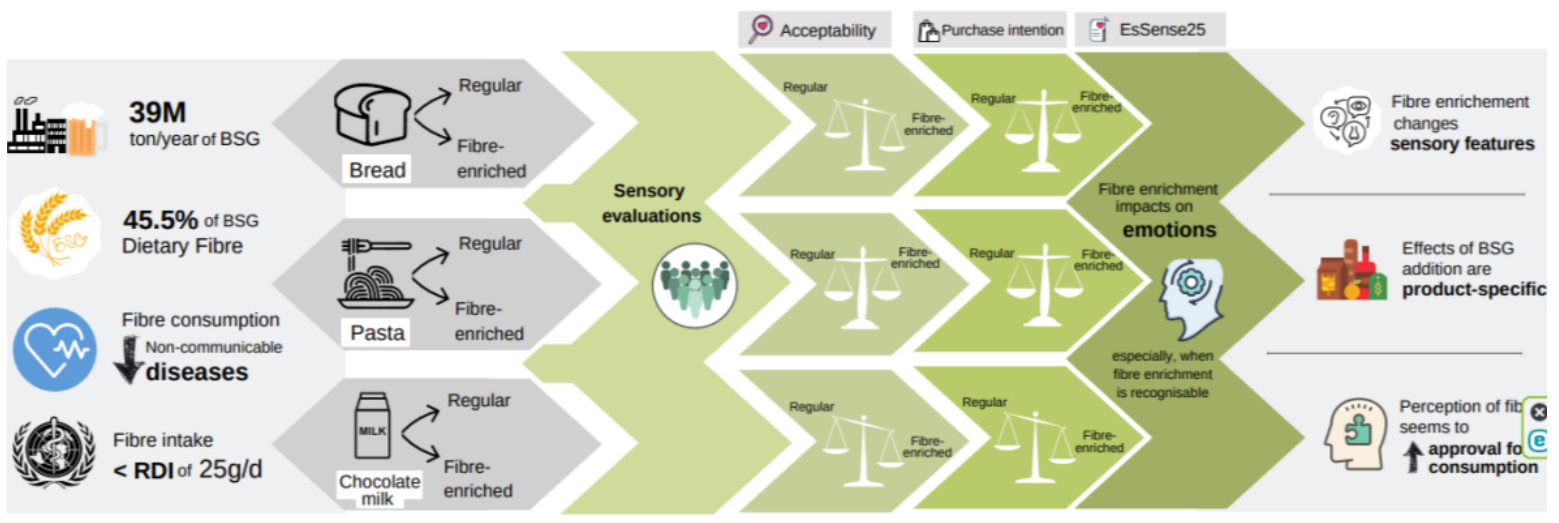

\section{ABSTRACT}

The aim was to formulate three different fibre enriched products by the addition of BSG and to evaluate the impact of fibre enrichment on the sensory quality, acceptability, and purchase intention under blind conditions. BSG was incorporated into bread, pasta and chocolate milk at levels of $8.3 \%, 2.8 \%$ and $0.35 \%(w / w)$, respectively. Fibre enriched products and their regular counterparts were evaluated together by consumers through a CATA questionnaire, EsSense 25 Profile, an overall acceptability rating and purchase intention ranking. Although fibre enriched bread and chocolate milk ranked lower in overall acceptability compared with their counterparts, no significant difference was found for fibre enriched pasta $(\mathrm{p}<0.05)$. Purchase intention did not differ significantly for bread or pasta $(\mathrm{p}<0.05)$, yet the reasons for purchasing them differed significantly $(p<0.05)$. Consumers probably recognized the fibre enrichment in these two and were willing to partially compromise on sensory attributes. Fibre enriched chocolate milk, nonetheless, scored significantly $(\mathrm{p}<0.05)$ lower in purchase intention than the control.

Keywords: BSG, brewery, by-product, acceptability, valorization, sensory. 


\section{INTRODUCTION}

In recent years, extensive research has been undertaken to identify ingredients and components that display some clear physiological activity, namely improving intestinal transit (Ranoket al., 2021; Frame et al., 2020), and immunological system (ReyesBecerril et al., 2021; Steed \& Macfarlane, 2009) or reducing cholesterol (Fukami et al., 2021), blood glucose (Niu et al., 2021, Mao et al., 2021), arterial hypertension (Krittanawong et al., 2021), or obesity (Zhu et al, 2021).

A worldwide fibre deficiency is observed in both developed and underdeveloped countries. A review by Stephen et al. (2017), revealed the daily average dietary fibre intake in adults for ten countries (including USA, UK and Spain), none of which reached the recommended amount. Although this recommendation varies depending on age and lifestyle, on average it should be greater than $25 \mathrm{~g} /$ day according to the World Health Organization (WHO). Fibre consumption has potential benefits to human health such as preventing chronic non-communicable diseases (NCDs) including obesity, diabetes and cardiovascular disease (Nirmala \& Joye, 2020, Lattimer \& Haub, 2010).

Insoluble fibre prevents constipation, while soluble fibre is positively associated with decreased absorption of cholesterol and glucose at the intestinal level (Selani et al., 2014). Indeed, a high dietary fibre intake has been correlated to a lower glycemic response in diabetic patients (Chau, Chen, \& Lin, 2004). This is especially relevant since NCDs are the leading causes of death in current times (WHO, 2020). Among them, cardiovascular diseases are the most common NCD globally, leading to an estimated 17,8 million deaths in 2017 (WHO, 2019). Furthermore, according to research published by the World Health Organization (WHO, 2020) the prevalence of obesity tripled between 1975 and 2016. An estimated of $39 \%$ of adults were overweight in 2016 and $13 \%$ suffered from obesity. Also, over $18 \%$ of children and adolescents were overweight or obese (WHO, 2020).

Brewery Spent Grain (BSG) is a by-product obtained during the brewing process, with an overall composition in dry matter of fibre (30-50\%), protein (19-30\%), lipids (10\%) and ash (2-5\%) (Lynch et al., 2016). The high amount of fibre as well as the high protein content in BSG, justifies its use as a functional ingredient in the preparation of food for human consumption.

According to the potential benefits of BSG as a raw material, development of new food products containing it has been investigated. To mention some of them; Cappa \& Alamprese (2017) studied the valorization of BSG trough fibre enriched egg pasta 
reaching an optimized formulation of $6,2 \%$ of BSG. It has also been studied together with mushrooms as an animal protein replacer and fibre enricher of smoked sausages containing 3-6\% of BSG (Nagy et al., 2017). Moreover, Garrett et al. (2021), obtained promising results for a snack chip containing $40 \%$ BSG inclusion.

When formulating products with fibre, it is necessary to consider the fact that fibre may impart a strong flavour, coarse texture and dry mouthfeel (Mudgil et al., 2017) for which consumers are sometimes reluctant to comprise sensory quality to (Grigor et al., 2015). This is more so if the product is mainly consumed for hedonic pleasure (Maehle et al., 2015) as in the cases reports by Curutchet et al. (2021) and Curutchet et al. (2019) in which cakes and cookies, respectively, were enriched with fibre by adding fruit pomace and resulted in a reduction in the overall acceptability and purchase intention. However, owing to the multiple health benefits derived from fibre enrichment, they can also be valued and consumed for their utilitarian nutritional value (Maehle et al., 2015). For instance, fibre enrichment did not have any perceivable effect on the overall acceptability of fermented pork sausages (Ham et al, 2015) and noodles (Karthiayani et al., 2021). Motivations driving food choice and tolerance vary from one food product to another.

A hedonic scale is a simple method of measuring the overall liking scores, which is considered the most informative assessment by a consumer. However, consumer perception of a product goes beyond overall liking, since it also includes extrinsic elements such as the perceived benefits, quality and wellness of the associated food. As said above, food choice is also determined by cognitive-affective factors such as perceived emotions, expectations and health attitudes (Leng et al, 2017; Macht, 2008). Those factors produce a top-down modulation of food perception and attention, that can modify consumer behaviour (Wegman et al, 2018). These extrinsic elements can be explained using more advanced approaches, such as the EsSense Profile and check-allthat-apply (CATA) as conscious methods. (Ng et al., 2013).

The aim of this work was to evaluate what sensory features generate Brewery Spent Grain used as fibre enrichment in different product categories (bread, pasta and chocolate milk) and their impact in consumer motivations and emotions.

\section{MATERIALS AND METHODS}

\section{Brewers Spent Grains flour obtention}


Brewers Spent Grains (BSG) were obtained from the Uruguayan brewing company Fábricas Nacionales de Cerveza S.A. BSG flour was produced by drying BSG in a convection oven at $55{ }^{\circ} \mathrm{C}$ for 72 hours and grounding it in a laboratory mill. The fraction that passed through a $1 \mathrm{~mm}$ mesh screen was used for the bread and pasta, while a 0.25 $\mathrm{mm}$ mesh screen was used for the chocolate milk. BSG flour was packed in polyethylene bags and kept at room temperature until use.

\section{BSG Composition}

Proximate analyses were performed on the BSG flour according to methods proposed by the Association of Official Analytical Collaboration (AOAC, 2019). Protein content was determined by Kjeldahl method and performed according to method 981.10 of the AOAC International with a conversion factor of 6.25. Fat content was determined by Soxtec method as described in AOAC 2003.5. Quantification of moisture and ash content were performed in accordance with AOAC 925.09 and AOAC 923.02, respectively. Total dietary fibre was measured according to AOAC 985.29. Carbohydrates were calculated by difference (i.e., all other nutrients were summed and subtracted from the total weight of the sample)Error! Reference source not found.. Sodium was estimated based on the v alues obtained by Arcia et al. (2018).

\section{Product formulation}

As consumers' expectations and tolerance vary from one food product to another, three different ones were selected to study consumers' responses. These were: bread and pasta, which could be regarded as utilitarian products, and chocolate flavored milk, in representation of a hedonic product. The weighting of attributes involved in food choices is a complex phenomenon and may vary between utilitarian and hedonic food products. The amount of BSG flour used in each product was adjusted to reach a total fibre content of $2.5 \mathrm{~g}$ of dietary fibre per serving size, allowing the products to bear the "Source of fibre" claim according to Uruguayan law (Mercosur, 2012). This resulted in a content of dietary fibre of $2.5 \%, 5.0 \%$ and $1.25 \%$ for pasta, bread and chocolate milk respectively, which were used as the upper limit for BSG addition in the fibre enriched products. These products also comply with Codex Alimentarius (CXG 23-1997 (2013)) Source of Fibre claim, particularly the condition which calls for a minimum of $10 \%$ of the daily reference value per serving. As a result, three product formulations with BSG flour as an ingredient 
were developed and studied: fibre enriched bread, fibre enriched pasta and fibre enriched chocolate milk, with BSG flour concentrations of $8.3 \%, 2.8 \%$ and $0.35 \%$, respectively. Non-added-BSG formulations were also developed by replacing flour or milk from the fibre enriched formulations and used as control. These were regular bread, regular pasta and regular chocolate milk.

\section{Bread}

Bread was formulated according Arcia et al. (2018), formulation is detailed in (Table 1), all ingredients were bought at a locally.

The dough was formed in KitchenAid Professional Bowl-Lift Stand Mixer 5KSM7990X using the spiral dough hook, 6.9 L bowl and a low-speed setting. For the fibre enriched bread, dry ingredients were first mixed with water for 15 minutes. Oil and BSG flour were then added in turns and mixed for 5 minutes after each addition. The regular bread dough was made likewise except for the final mixing which was omitted. Once the doughs were formed, they were left to bulk ferment at $35^{\circ} \mathrm{C}$ and $60 \% \mathrm{RH}$ for 30 minutes. Doughs were shaped in a $27.5 \times 15.0 \times 6.5 \mathrm{~cm}(\mathrm{LxWxH})$ loaves pans and left to further ferment for 50 minutes under the same conditions. The proofed breads were baked at $190{ }^{\circ} \mathrm{C}$ for 30 minutes in a convection oven. After baking, they were cooled for 20 minutes, packed in sealed polyethylene bags and stored refrigerated until sensory evaluation took place 24 hs. later.

Table 1. Formulations of Fibre enriched bread and regular bread

\begin{tabular}{lcc}
\hline Ingredients & Fibre enriched Bread (\%) & Regular Bread (\%) \\
\hline Water & 33.37 & 33.37 \\
Wheat flour & 53.30 & 45.00 \\
BSG flour $(<1 \mathrm{~mm})$ & 8.30 & - \\
Sunflower oil & 4.86 & 4.86 \\
Granulated sugar & 3.60 & 3.60 \\
Skim milk powder & 3.20 & 3.20 \\
Salt & 1.20 & 1.20 \\
Instant yeast & 0.47 & 0.47 \\
\hline
\end{tabular}

\section{Pasta}

Ingredients for the pasta included: wheat flour 000, BSG flour (1 mm particle size), water and eggs. Formulation was adapted from the pasta maker machine recipe book (Table 2). All ingredients were bought at a local supermarket. 
Fresh pasta was made with a pasta maker machine (HR2355/08, Philips), using the standard program and following its instructions. Spaghettis were cut at a length of approximately $30 \mathrm{~cm}$ and left at room temperature until the moment of cooking. Pasta was always consumed the same day it was made.

Table 2. Formulations of Fibre enriched Pasta and Regular Pasta

\begin{tabular}{lcc}
\hline Ingredients & Fibre enriched Pasta $(\%)$ & Regular Pasta $(\%)$ \\
\hline Water & 11.97 & 11.97 \\
Wheat flour & 70.06 & 72.86 \\
BSG flour $(<1 \mathrm{~mm})$ & 2.80 & - \\
Egg & 15.97 & 15.97 \\
\hline
\end{tabular}

\section{Chocolate milk}

Regular chocolate milk formulation was formulated according to a locally well-known commercial chocolate milk, to which BSG flour was then blended in to create the fibre enriched version. Chocolate milk was made in a mixer by mixing semi-skimmed milk (1.5\% fat content), BSG flour ( $250 \mu \mathrm{m}$ particle size), cocoa powder (12\% fat content), granulated sugar, carrageenan type A, carboxymethyl cellulose (CMC) and Givaudan chocolate flavoring for 2 minutes. Formulations are detailed on Table 3. All ingredients were bought at a local supermarket.

Table 3. Formulations of the Fibre enriched Chocolate milk and Regular Chocolate milk.

\begin{tabular}{lcc}
\hline Ingredients & $\begin{array}{c}\text { Fibre enriched Chocolate } \\
\text { milk (\%) }\end{array}$ & $\begin{array}{c}\text { Regular Chocolate milk } \\
(\boldsymbol{\%})\end{array}$ \\
\hline Semi-skim milk & 89.47 & 89.82 \\
Granulated sugar & 7.00 & 7.00 \\
Cacao powder & 3.00 & 3.00 \\
BSG flour $(<250 \mu \mathrm{m})$ & 0.35 & - \\
Carrageenan Type A & 0.075 & 0.075 \\
CMC & 0.075 & 0.075 \\
Chocolate flavoring & 0.03 & 0.03 \\
\hline
\end{tabular}

\section{Consumer Evaluation Sessions}

To study acceptability of products, one session was held for each product under blind conditions. 110, 119 and 111 consumers participated for bread, pasta and chocolate milk product sessions respectively. The panelists, male and female, ranged between 18 and 70 years old. For the sensory evaluation, the participants were provided with two samples, one containing the regular product and the other one containing the fibre enriched 
product. These samples were given without any information related to their composition or health effects. Sensory evaluation took place in the laboratories and pilot plant of Catholic University of Uruguay.

\section{Bread}

The breads where prepared the previous day and refrigerated in plastic bags for avoiding moisture loss. The day of evaluation, breads were removed from the refrigerator and left to warm up to room temperature. Half slices of fibre enriched bread and regular bread (approximately $15 \mathrm{~g}$ ) were served in biodegradable plastic plates coded with a three-digit number. Water was available to consumers.

\section{Pasta}

Fresh pasta was made the day of evaluation. BSG-added and regular pasta were cooked in abundant salted ( 1 tbl. spoon) water for 15 minutes, drained and seasoned with extra virgin olive oil (1 tbl. spoon). Approximately $15 \mathrm{~g}$ of cooked spaghettis were served in white polystyrene cups coded with a three-digit number. Samples were maintained warm until evaluation. Water was available to consumers.

\section{Chocolate milk}

Chocolate milk samples were prepared, refrigerated and evaluated in less than 24 hours after making. Samples were served at $5^{\circ} \mathrm{C}$ in plastic cups coded with three-digit number.

\section{Sensory evaluation procedures}

Each consumer then randomly evaluated one of the two given samples.

\section{Product perception.}

Consumers were asked to rate overall acceptability using a nine-point hedonic scale (1disliked extremely to 9-like extremely), followed by nine-point scale activation question as to how the product made them feel (1-relaxed to 9-excited). Product-specific "Just about right" (JAR) questions were then asked about product characteristics: saltiness in bread and flavor, consistency and sweetness in chocolate milk. Subsequently, consumers completed a check-all-that-apply (CATA) product-specific questionnaire to describe the samples. The attributes presented had been previously determined in a preliminary study. The attributes options were randomly presented to participants to avoid order effects. 
Finally, purchase intention was measured by a five-point scale from 1: would definitely not buy to 5: would definitely buy, followed by a CATA questionnaire to uncover the reason behind their decision (Table 4).

Table 4. Question of purchase intention: reasons for buying or not buying the products.

\section{Why would you buy it?}

1. Because it is healthy

2. Because it is tasty

3. To avoid weight gain

4. Because it is high in calories

5. Because it is good for my family

6. Because I want to include fibre in my diet

7. Because my kids would like it

\section{Why wouldn't you buy it?}

1. Because it does not seem healthy

2. Because it is distasteful

3. Because it is not the one I always buy

4. Because I do not need fibre

5. To prevent weight gain

6. Because I think it is bad for my family

7. Because it seems expensive

8. Because I don't want to include fibre in my diet

9. Because my family would not like it

\section{Product-evoked emotions.}

EsSense25 was used to collect emotional response data based on method suggested by Nestrud et al., 2016. The twenty-five emotions were first translated into Spanish by authors. As Spanish and Portuguese are closely related due to their Latin roots, Spanish translations were then compared to the Portuguese terms suggested by Polizer et al., 2018. Emotions included on EsSense 25 profile are classified according to their nature in positive, negative and unclassified subgroups (Yang et al., 2020).

Consumers were presented with a five-point intensity scale (1-Nothing, 2-Slightly, 3Mildly, 4-Very and 5-Extremely) and asked to select the most accurate intensity for every one of the twenty-five emotions. The emotions were randomly presented to participants to avoid order effects.

\section{Data Analysis}

Acceptability, purchase intention and EsSense 25 results obtained were subjected to Student's t-test analysis with a significance level of 0.05. Raw CATA data was converted into binary data based on frequency of citation (1 - cited, 0 - non-cited). The 
nonparametric Cochran's Q test was then performed on the binary CATA data to detect significant differences $(\mathrm{p}<0.05)$ among fibre enriched and regular samples for each attribute. Based on resent research published by Yang et al., (2020), EsSense25 results were subjected to Student's t-test analyses at a significance level of 0.05 to investigate difference in the intensity of emotions between fibre enriched products and their counterparts. All statistics analysis was performed using XLSTAT software (2019 version, Addinsoft Inc. New York, N.Y., USA).

\section{RESULTS AND DISCUSSION}

\section{BSG flour composition}

BSG flour composition is shown in Table 5, including the contents for protein, fat, carbohydrates, dietary fibre, ash, sodium and moisture. Results are notable feature, the total dietary fibre content is higher than content obtained by Arcia et al., (2018) which accounted for $44,61 \pm 0,29 \%$. General composition is in the reported range (Lynch et al., 2016). Owing to the significant amount of this nutrient, it was possible to formulate products with the addition of BSG as a functional ingredient and for them to bear the Source of Fibre claim.

Table 5. BSG flour composition per 100g.

\begin{tabular}{lc}
\hline Component & Mean Value \pm SD \\
\hline Proteins $(\mathrm{g})$ & $24.9 \pm 0.02$ \\
Lipids $(\mathrm{g})$ & $6.28 \pm 0.16$ \\
Carbohydrates $(\mathrm{g})$ & $16.24^{*}$ \\
Total dietary fibre $(\mathrm{g})$ & $45.47 \pm 0.34$ \\
Ash $(\mathrm{g})$ & $2.81 \pm 0.25$ \\
Sodium $(\mathrm{mg})$ & 240 \\
Moisture $(\mathrm{g})$ & $4.3 \pm 0.4$ \\
\hline * Carbohydrates were determined by difference. &
\end{tabular}

\section{Hedonic analysis and emotional profile}

\section{Bread}

Acceptability differed significantly for regular and fibre enriched bread (Table 6). Similar results were obtained by Amoriello et al. (2020) and by Arcia et al. (2018), where the BSG addition to bread dropped consumers overall acceptability. For purchase intention, no significant difference was found, suggesting that consumers may have identified the health benefits from fibre enriched bread, even though no information was given, and 
were willing to compromise on buying them. According to Maehle et al. (2015), for utilitarian products such as bread, sensory quality is not the main driver of consumer choice as for hedonic products. Consumers may have identified the health benefits due to whole grains natural darker color, as reported by Combest \& Warren (2018), and compromise on them.

Table 6. Acceptability and purchase intention for Bread, Pasta and Chocolate milk; regular and fibre enriched product.

\begin{tabular}{lcc}
\hline Product & Acceptability & Purchase intention \\
\hline Bread & & \\
Regular bread & $7.10 \pm 1.48^{\mathrm{a}}$ & $3.93 \pm 1.00^{\mathrm{a}}$ \\
$\begin{array}{l}\text { Fibre enriched bread } \\
\text { Pasta }\end{array}$ & $6.44 \pm 2.06^{\mathrm{b}}$ & $3.75 \pm 1.26^{\mathrm{a}}$ \\
$\begin{array}{l}\text { Regular pasta } \\
\text { Fibre enriched pasta }\end{array}$ & $6.87 \pm 1.45^{\mathrm{a}}$ & $4.14 \pm 0.93^{\mathrm{a}}$ \\
$\begin{array}{l}\text { Chocolate } \text { milk } \\
\text { Regular chocolate milk }\end{array}$ & $6.91 \pm 1.91^{\mathrm{a}}$ & $4.00 \pm 1.20^{\mathrm{a}}$ \\
Fibre enriched chocolate milk & $6.47 \pm 1.86^{\mathrm{a}}$ & $3.55 \pm 1.26^{\mathrm{a}}$ \\
$\begin{array}{l}\text { Acceptability and Purchase intention expressed as (mean } \pm \text { SD). For each category product scores not sharing letters } \\
\text { are significantly different }(\mathrm{p}<0.05) \text { according to Student's T-test. }\end{array}$
\end{tabular}

Among the reasons for consumers choosing to buy the fibre enriched bread (67\%), the most frequently mentioned were that it is healthy $(64 \%)$, tasty $(81 \%)$, to include fibre in their diet (57\%) and to avoid weight gain (19\%) (Figure 1, a). Except for being tasty, all the other reasons were more frequently selected for fibre enriched bread than regular bread $(p<0.05)$. Despite the high frequency of choice of the tasty attribute for fibre enriched bread, it was more commonly selected as a reason for buying the regular bread $(\mathrm{p}<0.05)$, which accounted for a vast $98 \%$ of the consumers willing to buy the latter.

For both, fibre enriched and regular bread, the main reason for not buying them was related to their taste, where fibre enriched bread ranked higher than regular bread ( $\mathrm{p}<0.05$ ): $61 \%$ for fibre enriched compared to $33 \%$ for regular bread (Figure 1, b). Sensory properties have already been reported to be the main reason for not consuming a fibre enriched product (Laureati et al., 2016). Unlike for regular bread, price resulted in a relatively common reason for not buying the fibre enriched one $(p<0.05)$. This is supported by Quagliani et al. (2017) which states expensiveness as a misperception consumers have towards fibre enriched products. Furthermore, the reason related to consumers' families not liking this type of product may be due to the low popularity of 
fibre enriched products in children and adolescents (Meynier, et al, 2020; Kamar et al., 2016).

a)

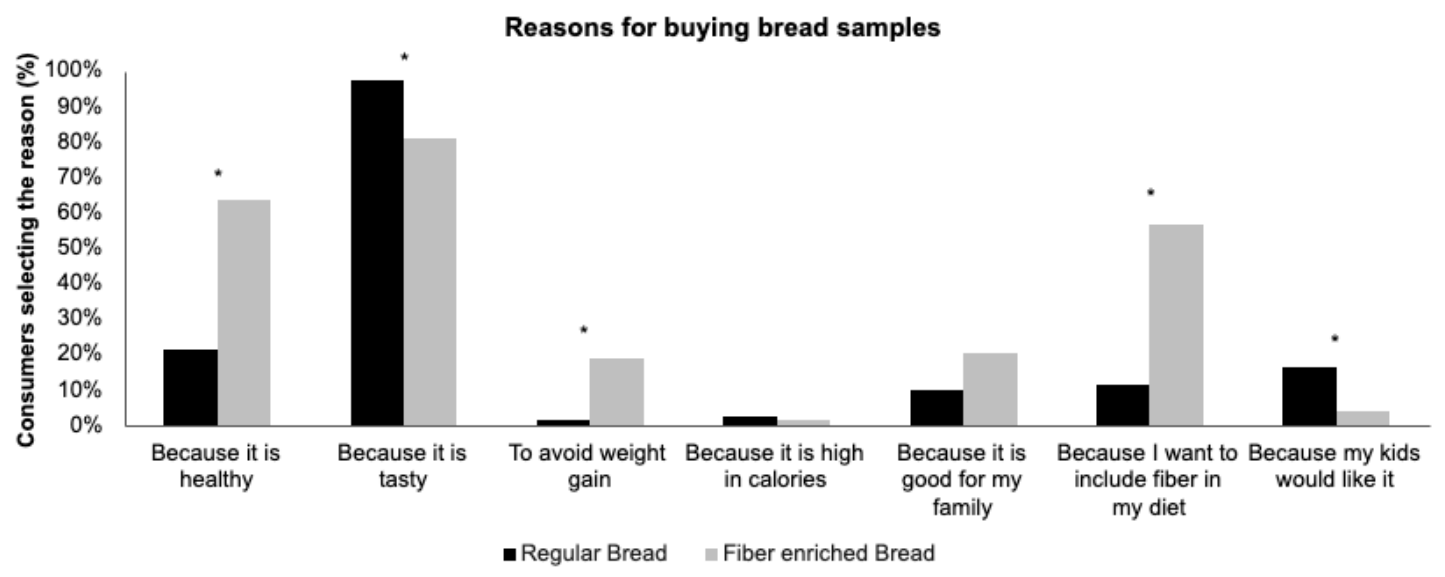

b)

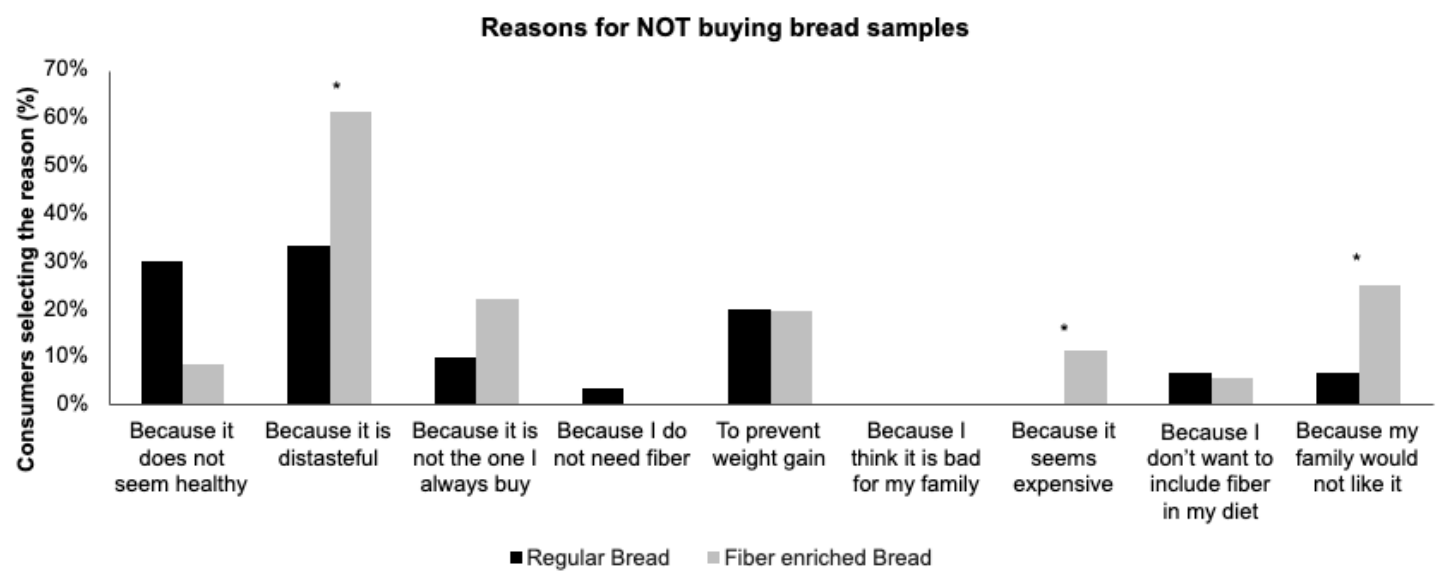

Figure 1. Reasons for buying (a) and Not buying (b) breads.

With respect to Check-all-that-apply (CATA) questionnaire, 12 out of the 21 attributes detailed showed a significant difference in terms of frequency of mention (Figure 2). Specifically, the attributes most used to describe fibre enriched bread were fibrous, natural, soft, compact, fluffy and dry. For regular bread soft, fluffy, natural and moist were the attributes most frequently selected. Despite many of these attributes being recurrent in both bread samples, repeated frequent attributes except for natural differed significantly on the frequency of mention. Fibre enriched breads have already been reported to have a decreased specific volume compared to non-enriched (Amoriello et al., 2020; Olubunmi et al., 2015). Additionally, consumers may have described the fibre enriched bread as Dry since fibre has a high-water holding capacity (Zhou et al., 2020) and free water may seem scarce in this type of bread. 


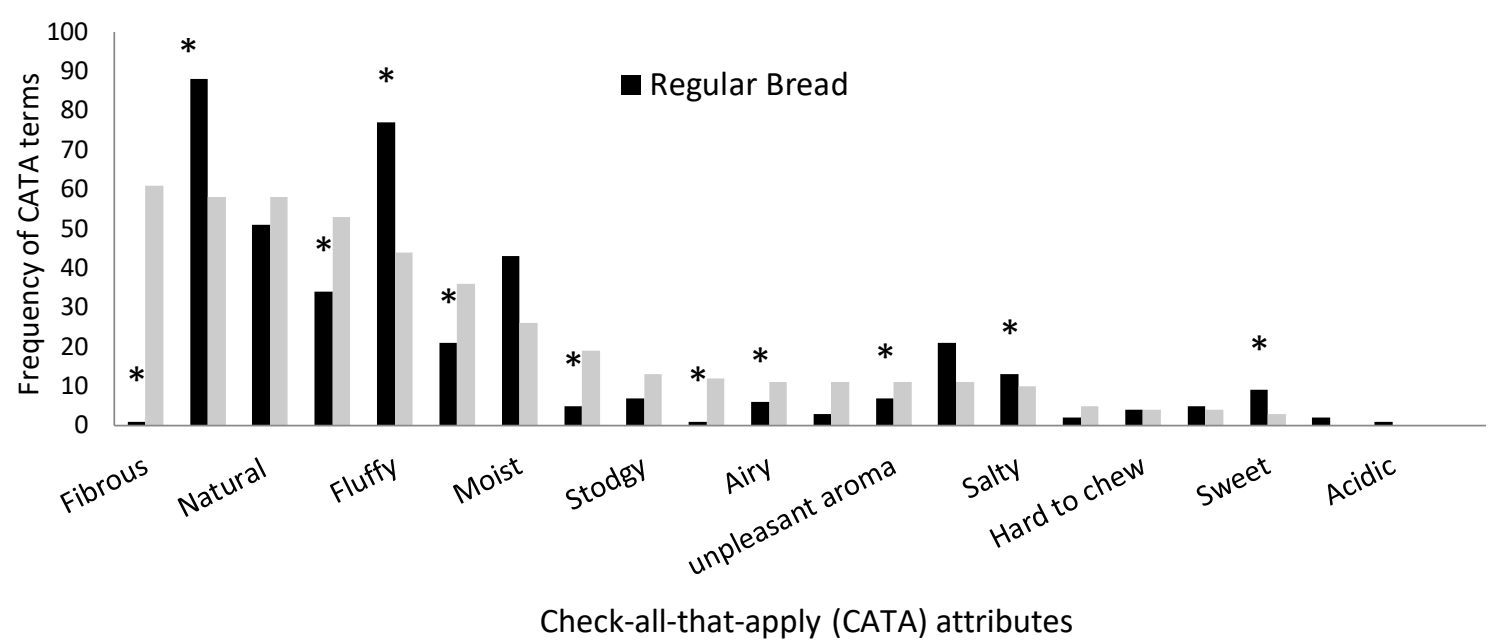

Figure 2. Frequency of check-all-that-apply (CATA) terms for the Fibre enriched Bread and the Regular Bread. *indicates significative difference at $\mathrm{p}<0.05$.

Five of twenty-five emotional terms showed significant difference. Two were positive emotions - Warm $(\mathrm{p}=0.000)$ and Active $(\mathrm{p}=0.027)$ - being participant more active after testing the regular bread but the opposite occurred with warmness. Additionally, Tame $(\mathrm{p}=0.001)$ and Guilty $(\mathrm{p}=0.005)$ showed significative difference. Participants felt more guilty and less tame after testing regular bread. Finally, respondents felt significantly more Bored $(\mathrm{p}=0.000)$ when consuming the fibre enriched bread.

\section{Pasta}

For pasta, no significant differences were found in either acceptability or purchase intention between the regular and the fibre enriched product (Table 6). This first result is in accordance with Laureati, et al. (2016) who did not find a significant difference between the liking of traditional pasta and the liking of 10\%-wheat-bran-added pasta. The fact that consumers were equally willing to buy regular and fibre enriched pasta is understandable based on the previous result on liking. This was an interesting finding as only a $15.8 \%$ of the total grains consumed on a given day are whole grains, according to the U.S. Department of Health and Human Services (Ahluwalia et al., 2019). It may thus seem that respondents were not against fibre enriched pasta, but unaware of it as a replacement to regular pasta (Barret et al., 2020; Laureati et al., 2016). Indeed, Barret et al., (2020) reported that their focus group participants chose whole grain breads more regularly than whole grain pasta, for which they usually opted for the refined version.

In this case, the most frequently given reasons for buying fibre enriched pasta were because it is tasty $(86,7 \%)$, healthy $(58,9 \%)$ and because they want to include fibre in 
their diets $(36,7 \%)$ (Figure 3, a). The main reason for buying regular pasta was that it is tasty $(94,1 \%)$; while all the other reasons were negligible in terms of frequency of mention $(<20 \%)$. Significant differences $(p<0.05)$ were detected in the frequency of mention of Healthy and To include fibre in my diet between the two products.

On the other hand, main reasons for not buying fibre enriched pasta were because it is distasteful $(66,7 \%)$ and because is not the one they always buy $(48,1 \%)$ (Figure $3, \mathrm{~b})$. The first one is once again related to fibre imparting a strong flavour, coarse texture and dry mouthfeel, as argued for bread samples (Mudgil et al., 2017). In addition, the last reason can be associated with food neophobia which is defined as the reluctance to eat new foods (Domjan, 2018) and has already been reported to be a barrier to novel foods consumption (Tuorila \& Hartmann, 2019).
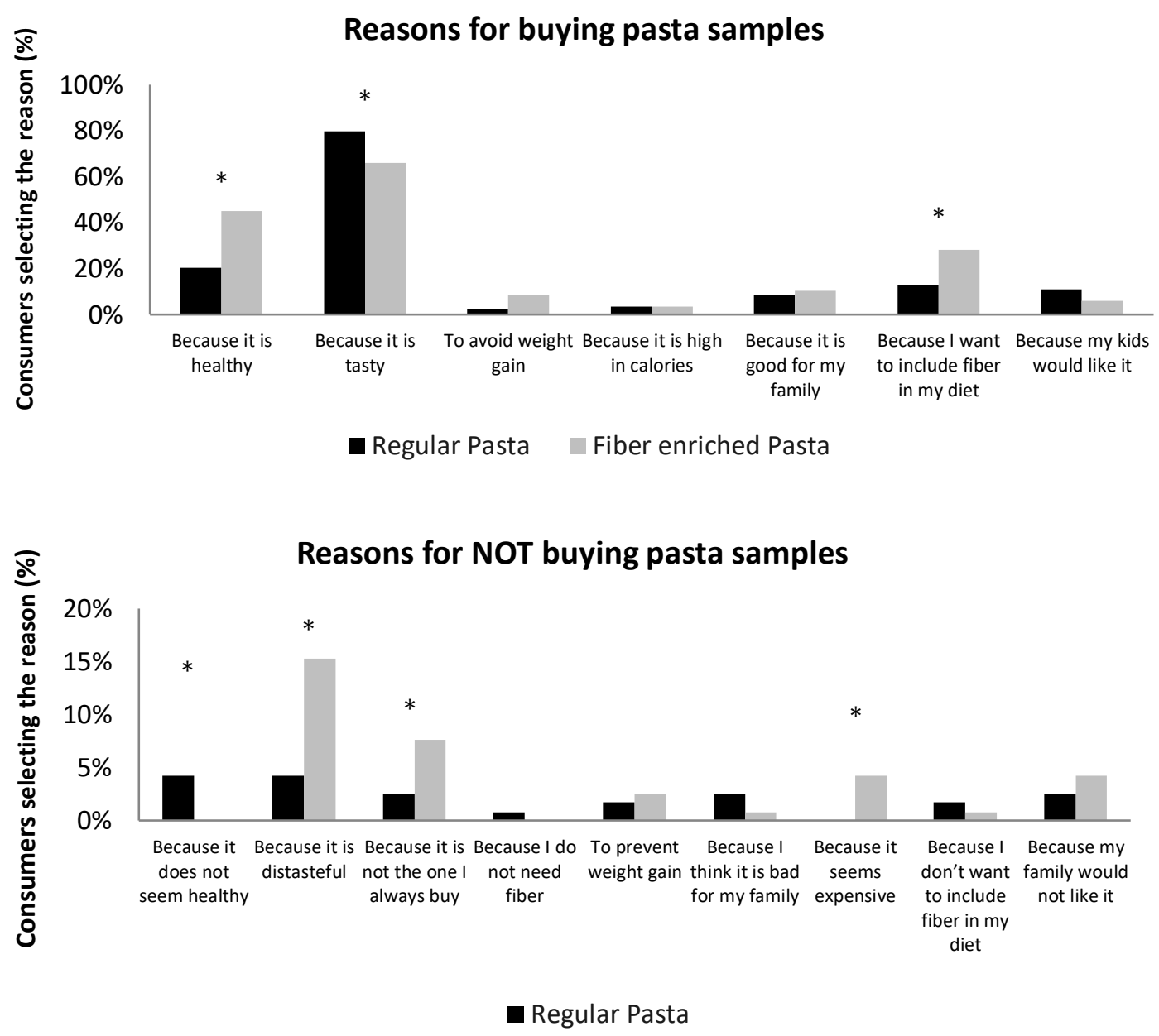

Figure 3. Reasons for buying (a) and Not buying (b) pastas

According to check-all-that-apply questionnaire analysis, for 11 out of the 20 terms presented to consumers, significant differences were observed in their frequency of choice for pasta (Figure 4). Participants associated the fibre enriched pasta with the 
attributes: natural, fibrous, granulated, coarse, dark, gritty and strange taste. On the other hand, the terms soft, uniform, homogeneous, and flexible were associated with regular pasta. Moreover, both pastas were frequently described as tasty with no significative difference between them.

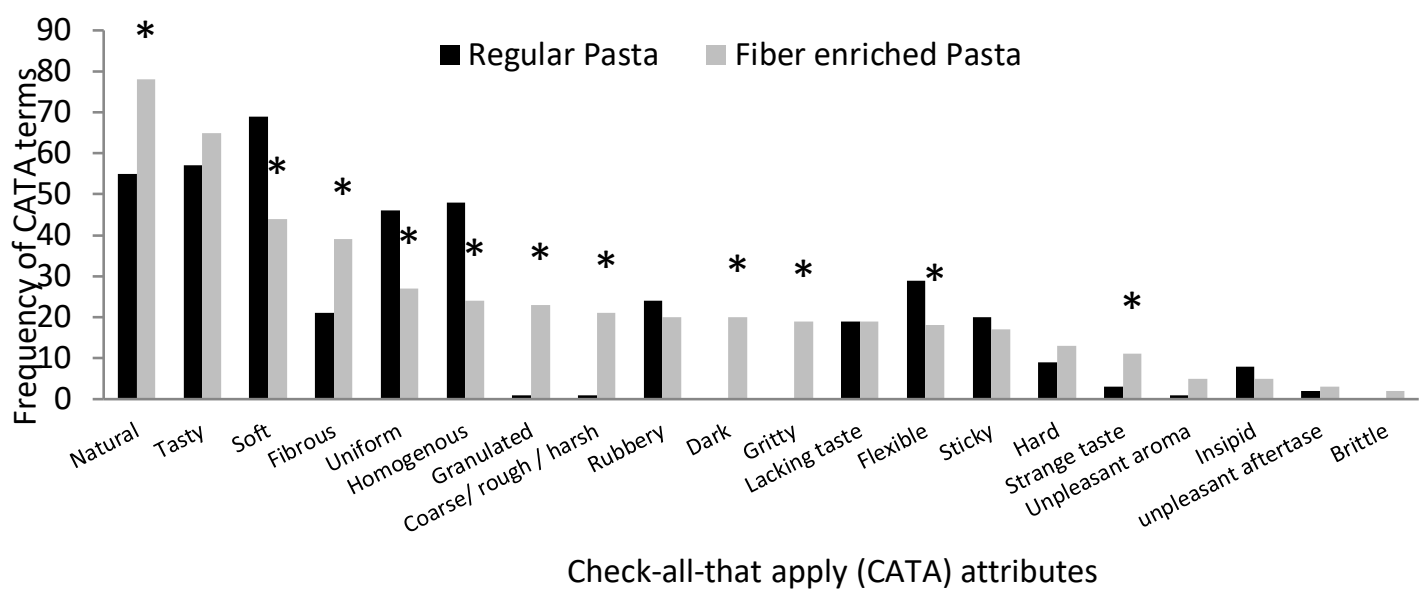

Figure 4. Frequency of check-all-that-apply (CATA) terms for the Fibre enriched Pasta and the Regular Pasta. * indicates significative difference at $\mathrm{p}<0.05$.

Numerous texture attributes differed significantly in frequency of mention between both samples, suggesting that addition of BSG to pasta produces textural and flavor changes. This is not surprising when compared to results obtained by Makhlouf et al. (2019), who studied whole barley incorporation into regular pasta for a total final dietary fibre concentration of $2.6 \%(\mathrm{w} / \mathrm{w})$ Their results showed that both firmness and adhesiveness decreased with the amount of barley being added; whilst taste and overall linking ranked significantly lower for barley-added pasta when compared to the control sample. This is apparent by the results of CATA attributes - fibre enriched pasta was described as more Fibrous, Granulated, Coarse and Gritty and less Soft, Uniform, Homogenous and Flexible compared to regular sample. Certainly, addition of fibre interferes with gluten network and prevents cohesiveness of the dough. As a result, starch granules are more easily lost during cooking and the quality of the final product decreases (Makhlouf et al., 2019). It should be noted that a possible solution to these negative effects may be the addition of xanthan gum and vital gluten. Krawęcka et al. (2020), obtained equal texture and flavor characteristics for both $5 \%(\mathrm{w} / \mathrm{w}) \beta$-glucans-added pasta and control sample by adding $5 \%$ xanthan gum and vital gluten.

Moreover, the color difference detected between samples is due to BSG flour being darker than wheat flour as already observed by Nocente et al. (2019) in BSG-enriched pasta. A decrease in yellowness and increase in brownness and redness was observed for all 5\%, 
$10 \%$ and $20 \%(\mathrm{w} / \mathrm{w}) \mathrm{BSG}$ addition levels in dried pasta. This may have decreased its acceptability as the yellow color is highly valued by consumers of durum wheat pasta (Nocente et al., 2019).

Fourteen of twenty-five emotional terms presented significant difference in their rating when comparing fibre enriched and regular pasta. These show that both products were perceived in very different way. Two negative emotional terms - Bored $(p<0.0001)$ and Disgusted $(\mathrm{p}<0.0001)$ - presented significant difference. While the first term was significantly more elicited for BSG-added sample, for the latter the opposite occurred. Other emotions that present significative difference: Guilty $(p<0.0001)$ and Wild $(\mathrm{p}=0.036)$ were less frequently applied to fibre enriched pasta when compared to regular Pasta, and Tame $(\mathrm{p}<0.0001)$ rated higher for the fibre enriched.

\section{Chocolate milk}

Significant differences were found in both acceptability and purchase intention of chocolate milk products (Table 6). These differences were probably rooted in the fact that fibre inclusion introduces changes in the texture and flavour of the product, as evidenced by the CATA attributes and reasons for not purchasing the product (Figure 5).

Among consumers willing to buy fibre enriched chocolate milk (39.6\%), most of them (95.5\%) stated that the taste was the main reason for purchasing (Figure 5, a). However, this was also the main cited reason for buying regular chocolate milk, scoring a significantly higher frequency of mention compared to the first one $(p<0.05)$. This difference in frequency of choice is mostly due to the higher percentage of consumers buying the regular sample $(60.4 \%)$.

In addition, the main reason for not buying the fibre enriched chocolate milk was due to its taste; this being more frequently selected than for the regular product $(\mathrm{p}<0.05)$ (Figure $5, \mathrm{~b})$. This attribute was also chosen for bread and pasta as main reasons for not buying the products. Ktenioudaki et al. (2013) reported that the incorporation of BSG into baked snacks altered the odor profile of the snacks, in addition to their taste and overall acceptability. Researchers associated this unpleasant odour to compounds deriving from fermentation and Maillard reaction, including 3-methyl-butanal, 2,3 butanedione and 2methy-butanal which were present in high quantities in both BSG flour and the BSG snacks. 

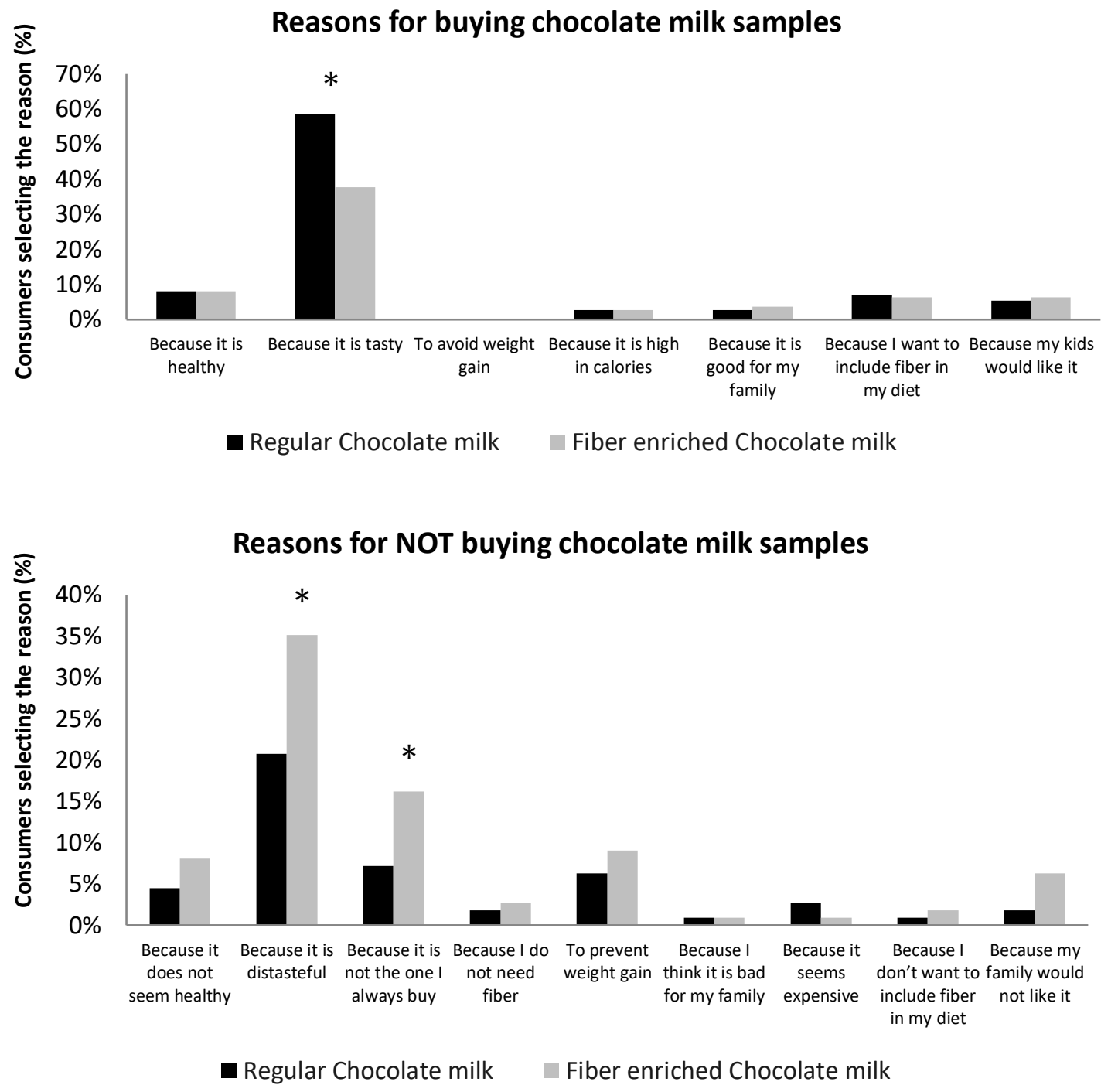

Figure 5. Reasons for buying (a) and Not buying (b) chocolate milk.

In this case, out of the 20 terms presented in CATA questionnaire, 7 presented significant differences $(p<0.05)$ in their frequency of choice for chocolate milk (Figure 6). Both chocolate milks were frequently associated with the attributes smooth, strong chocolate flavour and natural. However, the attributes gritty, artificial, coarse, aftertaste, strange taste, unpleasant aroma and greasy distinguished the fibre enriched chocolate milk from the regular one $(\mathrm{p}<0.05)$. Those attributes may explain the significative lower acceptability obtained for the BSG added product, affecting both, product texture and flavor. 


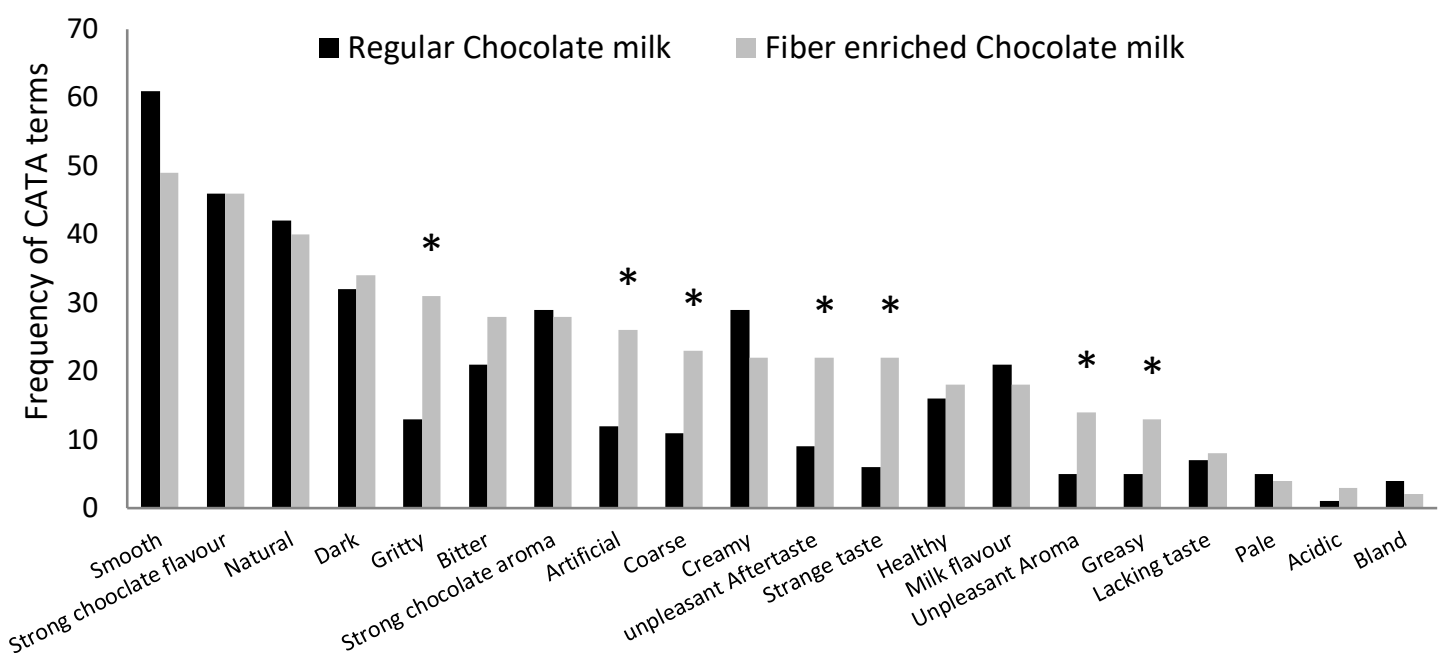

Check-all-that apply (CATA) attributes

Figure 6. Frequency of check-all-that-apply (CATA) terms for the Fibre enriched Milk chocolate and the Regular Milk chocolate. * indicates significative difference at $\mathrm{p}<0.05$.

Acceptability for fibre enriched milk has not been thoroughly studied in literature. However, its addition to other fluid dairy products, such as yoghurt, has been investigated. Particularly, Tomic et al. (2017) evaluated the sensory characteristics and consumer acceptance of fibre enriched yoghurts, reporting a significantly lower acceptability compared to the control sample, caused primarily by a gritty or sandy texture. This conclusion is in accordance with the results obtained in this study, where fibre enriched chocolate milk was significantly less accepted than the regular one and the Gritty attribute was selected by $30 \%$ of participants for the BSG product (12\% for the regular chocolate milk). López et al. (2016) studied the perceived oral grittiness of multiparticulate formulations and positively correlated it with the amount and size of particles being dispersed in the media. The product matrix has also been reported to greatly influence the particle size detection threshold, concretely particles being dispersed in liquid matrices are easier to detect than the ones in solid matrices (Santagiuliana et al., 2019). Although the BSG particle size used for fibre enriched chocolate milk was smaller than for fibre enriched bread and pasta, it was still considerably large $(>200 \mu \mathrm{m})$ compared to detection thresholds for cellulose particles $(1.5 \% \mathrm{w} / \mathrm{w})$ in viscous low-fat quark and semi-solid high-fat processed cheese which are estimated to be $52 \mu \mathrm{m}$ and $82 \mu \mathrm{m}$, respectively (Santagiuliana et al., 2019). In addition, the product matrix being liquid is likely to have facilitated the perception of Grittiness compared to for semi-solid or solid foods. For all 
the above, unpleasant Roughness and Grittiness was still perceived albeit BSG concentration being considerably low $(0.35 \% \mathrm{w} / \mathrm{w})$.

Table 7. Emotional response intensity means ratings for Bread, Pasta and Chocolate milk; regular and fibre enriched.

\begin{tabular}{|c|c|c|c|c|c|c|}
\hline Term & $\begin{array}{c}\text { Fibre } \\
\text { enriched } \\
\text { Bread }\end{array}$ & $\begin{array}{c}\text { Regular } \\
\text { Bread }\end{array}$ & $\begin{array}{c}\text { Fibre } \\
\text { enriched } \\
\text { Pasta }\end{array}$ & $\begin{array}{c}\text { Regular } \\
\text { Pasta }\end{array}$ & $\begin{array}{c}\text { Fibre } \\
\text { enriched } \\
\text { Chocolate } \\
\text { milk } \\
\end{array}$ & $\begin{array}{c}\text { Regular } \\
\text { milk }\end{array}$ \\
\hline Warm & $2.88^{\mathrm{a}}$ & $2.29^{b}$ & $3.05^{\mathrm{a}}$ & $2.25^{b}$ & $2.49^{\mathrm{a}}$ & $2.78^{\mathrm{a}}$ \\
\hline Bored & $2.22^{\mathrm{a}}$ & $1.66^{b}$ & $2.70^{\mathrm{a}}$ & $1.54^{\mathrm{b}}$ & $1.87^{\mathrm{a}}$ & $2.18^{\mathrm{a}}$ \\
\hline Tame & $2.10^{\mathrm{a}}$ & $1.60^{b}$ & $2.55^{\mathrm{a}}$ & $1.69^{b}$ & $1.57^{\mathrm{a}}$ & $2.02^{\mathrm{b}}$ \\
\hline Guilty & $1.52^{\mathrm{a}}$ & $1.93^{b}$ & $1.58^{\mathrm{a}}$ & $2.28^{b}$ & $1.67^{\mathrm{a}}$ & $1.45^{\mathrm{a}}$ \\
\hline Active & $2.66^{\mathrm{a}}$ & $3.02^{\mathrm{b}}$ & $2.50^{\mathrm{a}}$ & $2.85^{b}$ & $2.64^{\mathrm{a}}$ & $2.67^{\mathrm{a}}$ \\
\hline Calm & $2.81^{\mathrm{a}}$ & $2.57^{\mathrm{a}}$ & $2.86^{\mathrm{a}}$ & $1.93^{b}$ & $2.81^{\mathrm{a}}$ & $2.41^{\mathrm{b}}$ \\
\hline Good Natured & $2.45^{\mathrm{a}}$ & $2.97^{\mathrm{a}}$ & $2.32^{\mathrm{a}}$ & $2.92^{\mathrm{b}}$ & $2.67^{\mathrm{a}}$ & $2.50^{\mathrm{a}}$ \\
\hline Interested & $3.14^{\mathrm{a}}$ & $2.93^{\mathrm{a}}$ & $3.05^{\mathrm{a}}$ & $2.95^{\mathrm{a}}$ & $2.66^{\mathrm{a}}$ & $2.64^{\mathrm{a}}$ \\
\hline Pleasant & $2.45^{\mathrm{a}}$ & $2.66^{\mathrm{a}}$ & $2.13^{\mathrm{a}}$ & $2.48^{b}$ & $2.71^{\mathrm{a}}$ & $2.99^{\mathrm{a}}$ \\
\hline Happy & $2.85^{\mathrm{a}}$ & $3.07^{\mathrm{a}}$ & $2.53^{\mathrm{a}}$ & $2.94^{b}$ & $3.01^{\mathrm{a}}$ & $2.71^{\mathrm{a}}$ \\
\hline Free & $2.59^{\mathrm{a}}$ & $2.80^{\mathrm{a}}$ & $2.10^{\mathrm{a}}$ & $2.69^{b}$ & $2.73^{\mathrm{a}}$ & $2.58^{\mathrm{a}}$ \\
\hline Joyful & $3.03^{\mathrm{a}}$ & $2.84^{\mathrm{a}}$ & $2.99^{\mathrm{a}}$ & $2.54^{\mathrm{b}}$ & $2.78^{\mathrm{a}}$ & $2.95^{\mathrm{a}}$ \\
\hline Nostalgic & $2.19^{\mathrm{a}}$ & $2.36^{\mathrm{a}}$ & $2.72^{\mathrm{a}}$ & $2.67^{\mathrm{a}}$ & $2.36^{\mathrm{a}}$ & $2.37^{\mathrm{a}}$ \\
\hline Satisfied & $2.71^{\mathrm{a}}$ & $2.88^{\mathrm{a}}$ & $2.24^{\mathrm{a}}$ & $2.53^{\mathrm{a}}$ & $2.80^{\mathrm{a}}$ & $2.58^{\mathrm{a}}$ \\
\hline Disgusted & $1.56^{\mathrm{a}}$ & $1.69^{\mathrm{a}}$ & $1.67^{\mathrm{a}}$ & $2.37^{b}$ & $1.87^{\mathrm{a}}$ & $1.80^{\mathrm{a}}$ \\
\hline Understanding & $2.89^{\mathrm{a}}$ & $3.02^{\mathrm{a}}$ & $2.94^{\mathrm{a}}$ & $3.04^{\mathrm{a}}$ & $2.80^{\mathrm{a}}$ & $2.87^{\mathrm{a}}$ \\
\hline Worried & $2.29^{\mathrm{a}}$ & $2.17^{\mathrm{a}}$ & $2.67^{\mathrm{a}}$ & $2.67^{\mathrm{a}}$ & $2.22^{\mathrm{a}}$ & $2.33^{\mathrm{a}}$ \\
\hline Adventurous & $2.56^{\mathrm{a}}$ & $2.44^{\mathrm{a}}$ & $2.86^{\mathrm{a}}$ & $2.60^{\mathrm{a}}$ & $2.31^{\mathrm{a}}$ & $2.39^{\mathrm{a}}$ \\
\hline Wild & $2.15^{\mathrm{a}}$ & $2.25^{\mathrm{a}}$ & $2.30^{\mathrm{a}}$ & $2.64^{b}$ & $2.06^{\mathrm{a}}$ & $1.97^{\mathrm{a}}$ \\
\hline Aggressive & $1.86^{\mathrm{a}}$ & $1.92^{\mathrm{a}}$ & $2.30^{\mathrm{a}}$ & $2.33^{\mathrm{a}}$ & $1.62^{\mathrm{a}}$ & $1.62^{\mathrm{a}}$ \\
\hline Mild & $2.16^{\mathrm{a}}$ & $2.18^{\mathrm{a}}$ & $2.27^{\mathrm{a}}$ & $2.42^{\mathrm{a}}$ & $2.08^{\mathrm{a}}$ & $1.65^{b}$ \\
\hline Good & $2.99^{\mathrm{a}}$ & $2.97^{\mathrm{a}}$ & $2.49^{\mathrm{a}}$ & $2.59^{\mathrm{a}}$ & $3.01^{\mathrm{a}}$ & $2.79^{\mathrm{a}}$ \\
\hline Loving & $2.46^{\mathrm{a}}$ & $2.45^{\mathrm{a}}$ & $2.52^{\mathrm{a}}$ & $2.15^{b}$ & $2.49^{\mathrm{a}}$ & $2.44^{\mathrm{a}}$ \\
\hline Enthusiastic & $2.97^{\mathrm{a}}$ & $2.98^{\mathrm{a}}$ & $3.08^{\mathrm{a}}$ & $2.99^{\mathrm{a}}$ & $2.70^{\mathrm{a}}$ & $2.71^{\mathrm{a}}$ \\
\hline Safe & $2.89^{\mathrm{a}}$ & $2.90^{\mathrm{a}}$ & $3.00^{\mathrm{a}}$ & $3.10^{\mathrm{a}}$ & $2.92^{\mathrm{a}}$ & $2.97^{\mathrm{a}}$ \\
\hline
\end{tabular}

For each category product scores not sharing letters are significantly different $(\mathrm{p}<0.05)$ according to Student's T-test.

Furthermore, although Bitterness was relatively more frequently used to describe the fibre enriched chocolate milk, its frequency of mention did not differ significantly between samples ( $\mathrm{p}<0.05)$. Tomic et al., (2017) reported that Bitterness had a negative influence 
in the flavor quality scores of $30 \mathrm{~g} / \mathrm{kg}$ fibre enriched yoghurts, which were significantly lower than for the $15 \mathrm{~g} / \mathrm{kg}$ counterparts. This result suggests that fibre addition may have increased the bitterness of the fibre enriched chocolate milk, yet its concentration was not high enough to exert a significant effect.

Just as Taste scored significantly higher in terms of frequency of mention among the reasons for not buying fibre enriched chocolate milk compared to the regular one $(\mathrm{p}<0.05)$, significant differences $(\mathrm{p}<0.05)$ were also found in frequency of mention of the following CATA attributes describing taste: Unpleasant aftertaste, Unpleasant aroma and Strange taste. Again, this shows the unpleasant and negative effects of incorporating BSG into foods (Ktenioudaki et al., 2013). Nonetheless, a decrease in sensorial properties (particularly smell and taste) has also been reported after incorporating cauliflower byproducts extracts to apple juice (Amofa-Diatuo et al., 2016), becoming apparent one of the greatest struggles of by-products valorization.

In the case of chocolate milk, 3 emotional terms showed significant difference. Calm $(\mathrm{p}=0.016)$ Mild $(\mathrm{p}=0.001)$ and Tame $(\mathrm{p}=0.002)$. Participants felt significantly milder after consuming fibre enriched chocolate milk, yet they felt tamer after testing the regular chocolate milk. A positive emotion also presented significative difference in its rating Calm with $\mathrm{p}=0.016$ - being more frequently elicited for the fibre enriched chocolate milk.

\section{Comparison of the fibre impact on different category of products}

For different food product categories, consumers hold specific sensory and hedonic expectations which subsequently affect their food perception and acceptance (Cardello et al., 1995). In fact, previous experiences, product characteristics and context shape expectations. Sensory attributes of the product must meet consumer expectations for the acceptability to be high. In this work, consumers responded differently to the fibre enrichment of bread, pasta and chocolate milk. Interestingly, consumer responses towards bread and pasta were remarkably similar. In neither products consumer showed a statistically difference in purchase intention between the regular and fibre enriched version. Amidst the reasons for buying the fibre enriched bread and pasta, consumers cited Healthy and To include fibre in my diet. These results confirm the ability of respondents to successfully recognize fibre enriched products and thus infer their health benefits. Knowledge about dietary fibre and its health effects has already been reported to be substantial among the general population (Yalçın et al., 2020). Generally, consumers 
showed positive preference for higher fibre products. Baixauli et al. (2008) confirmed that the fibre information provided on the labels was well understood by the consumers and led to higher scores.

In the case of chocolate milk, consumers could not recognize the addition of fibre to the product and instead perceived a strong and unexpected flavor, coming from BSG's strong aromatic compounds, enhanced due to it being in liquid state. Although some respondents mention the "nutty" flavor characteristic of the fibre enriched version, most did not, as shown by the low acceptability and purchase intention rating. Lack of awareness of its nutritional benefits may have prevented the "halo" effect, which is defined as a positive influence on the perception of a product due to an unrelated impression from another attribute (Li \& Dando, 2019; Biondi \& Camanzi, 2019). Indeed, communication of a product's health benefits can be a powerful marketing tool for the food sector due to its potential "halo" effect. For instance, Curutchet et al. (2021) reported an increase in liking for fibre enriched apple pomace cake when the claim Source of Fibre was displayed, showing the impact, or "halo" effect, of health claims on hedonic liking. Thus, although fibre enriched chocolate milk was not liked as much as the control, including the corresponding nutritional claims may bridge the gap between them. Pasta is the product whose emotional response differed the most, despite being the only one with no significant difference neither in acceptability nor in purchase intention. Differences in emotional response between regular and BSG enriched samples were evoked due to differences in their sensory features, as no information was provided. Five emotions were repeated in at least two categories and show significant difference between the fibre enriched and the regular one. Tame, Calm, Warm, Bored, Guilty and Active.

Only Tame had the same behaviour in the three food categories; certainly, fibre enrichment made consumers feel talmer. However, although consumers felt more Warm, Bored, Active and less Guilty when tasting fibre enriched pasta and bread, the opposite occurred for fibre enriched chocolate milk. This seems to indicate that the knowledge or perception of fibre enrichment provokes a distinct set of emotions.

Zanetta et al. (2021), studied the emotions evoked by beer consumption in blind and informed condition, finding that the label information provided to participants increased their acceptance, induce some positive emotions and increased the WTP for pure malt beers.

Emotions reported by consumers confirmed a top-down modulation produced by previous experiences referred to fibre content. In the context of bread and pasta, the sensory 
qualities of fibre were perceived as healthy. The top-down modulation is observed in the high score that the statement "because it is healthy" obtained as a motivation to purchase these products (Figures 1 and 3). It is also seen in the emotions chosen to describe each product. Bread and past with BSG evoked emotions associated with health (warm, bored, tame, active) while regular bread and pasta induced guilt, an emotion associated with highly caloric non-healthy food intake (Hur et al, 2015; Wansink et al, 2006). This pattern was not present in the milk because chocolate is strongly associated with hedonic expectations and, as previously said, fibre inclusion modified standard characteristics of the product.

\section{CONCLUSIONS}

In the current study, the effect of BSG addition to different food product categories was analyzed by sensory evaluations of both control and fibre enriched samples. The amount of BSG flour added to the fibre enriched products was enough for them to bear the claim Source of fibre according to Uruguayan legislation and Codex Alimentarius. The addition of fibre led to some changes in the acceptability and buying intention as well as in the product perception. Results showed that BSG enrichment had a significant effect on the sensory properties of all three products $(\mathrm{p}<0.05)$, affecting both texture and taste. Although the fibre enriched bread and fibre enriched chocolate milk ranked lower in overall acceptability compared with their counterparts, no significant difference was found between fibre enriched pasta and regular pasta $(p>0.05)$.

Interestingly, purchase intention did not differ significantly for either bread or pasta $(p>0.05)$, yet the reasons for purchasing them differed significantly $(p<0.05)$. It seems consumers were aware of fibre-enrichment in these two and were willing to partially compromise on sensory attributes. Fibre enriched chocolate milk, nonetheless, scored significantly lower in purchase intention than the regular product, probably due to the mouthfeel perception being affected by BSG particles and lack of awareness of it being a functional product.

Overall, the findings demonstrated that the effect of BSG addition is product-specific; while fibre enriched pasta and fibre enriched bread were approved by consumers, results for fibre enriched chocolate milk suggested the opposite. Ambivalence was seen in the emotions generated by the different fibre enriched products, depending on whether the 
fibre was perceived or not. When consumers perceived the fibre enrichment in the product, they approved consumption, feeling in general more confident.

Further research should focus on the effect of information on the emotions of fibre enriched products, and their effects on attention, to draw more in-depth conclusions.

\section{ACKNOWLEDGEMENT}

Authors are grateful to FNC S.A. (Montevideo, Uruguay) for providing the BSG.

\section{CONFLICT OF INTEREST}

The authors have declared no conflicts of interest for this article.

\section{ETHICAL STATEMENTS}

The research article submitted has ethics approval by CE-UCU Committee (Comité de ética en investigación con seres humanos de la Universidad Católica del Uruguay) (approved 20 June 2021).

\section{REFERENCES}

AOAC, Official Methods of Analysis of AOAC International. 19th ed., (2012). Gaithersburg: AOAC International.

Arcia, P., Curutchet, A., Cozzano, S., \& Rodríguez, S. (2018). "Bagazo de cervecería como ingrediente en el desarrollo de panificados. Impacto del rotulado en la intención de compra y aceptabilidad." Revista del Laboratorio Tecnológico del Uruguay, 16, 40-46. http://dx.doi.org/10.26461/16.02.

Amofa-Diatuo, T., Anang, D. M., Barba, F. J., \& Tiwari, B. K. (2017). Development of new apple beverages rich in isothiocyanates by using extracts obtained from ultrasound-treated cauliflower by-products: Evaluation of physical properties and consumer acceptance. Journal of Food Composition and Analysis, 61, 73-81. http://dx.doi.org/10.1016/j.jfca.2016.10.001. 
Amoriello, T., Mellara, F., Galli, V., Amoriello, M., \& Ciccoritti, R. (2020). Technological Properties and Consumer Acceptability of Bakery Products Enriched with Brewers' Spent Grains. Foods, 9(10), 1492. http://dx.doi.org/10.3390/foods9101492.

Baixauli, R., Salvador, A.; Hough, G.; Fiszman, S.M. (2008). How information about fibre (traditional and resistant starch) influences consumer acceptance of muffins. Food Quality and Preference, 19, 628-635. http://dx.doi.org/10.1016/j.foodqual.2008.05.002.

Barrett EM, Foster SI, Beck EJ. (2020). Whole grain and high-fibre grain foods: How do knowledge, perceptions and attitudes affect food choice? Appetite, 1,149, 104630.http://dx.doi.org/10.1016/j.appet.2020.104630.

Biondi, B. \& Camanzi, L. (2019). Nutrition, hedonic or environmental? The effect of Front-Of-Pack messages on consumers' perception and purchase intention of a novel food product with multiple attributes. Food Research International, 108962. https://doi.org/10.1016/j.foodres.2019.108962.

Cappa, C. \& Alamprese, C. (2017). Brewer's spent grain valorization in fibre enriched fresh egg pasta production: Modelling and optimization study. LWT - Food Science and Technology, 82, 464-470. https://doi.org/10.1016/j.lwt.2017.04.068.

Cardello, V. (1995). Food quality: Relativity, context and consumer expectations. Food Quality and Preference, 6, 3, 163-170.https://doi.org/10.1016/09503293(94)00039-X.

Chau, C.F., Chen, H.C., Lin, C.Y. (2004). Insoluble fibre-rich fractions derived from Averrhoa carambola: Hypoglycemic effects determined by in vitro methods. LWT- Food Science and Technology, 37(3), 331-335 https://doi.org/10.1016/j.lwt.2003.10.001.

Codex Alimentarius (CAC/GL 23-1997). FAO,2013. Guidelines for use of nutrition and health claims.

Curutchet, A., Trias, J., Tárrega, A. \& Arcia, P. (2021). Consumer response to cake with apple pomace as a sustainable source of fibre. Foods, 10(3), 1-12. https://doi.org/10.3390/foods10030499. 
Curutchet, A., Cozzano, S., Tárrega, A. \& Arcia, P. (2019). Blueberry pomace as a source of antioxidant fibre in cookies: Consumer's expectations and critical attributes for developing a new product. Food Science and Technology International, 25(8), 642-648. https://doi.org/10.1177/1082013219853489.

Combest, S. \& Warren, C. (2018). Perceptions of college students in consuming whole grain foods made with Brewers' Spent Grain. Food Science \& Nutrition, 7(1), 225-237. https://doi.org/10.1002/fsn3.872.

Domjan, M. (2018). Introduction to food neophobia: historical and conceptual foundations. In: Reilly, S. (ed.) Food Neophobia: Behavioral and Biological Influences, 15-30. Elsevier, Amsterdam.

Garrett, R., Bellmer, D., McGlynn, W., Rayas-Duarte, P. (2021). Development of New Chip products from Brewer's Spent Grain.Journal of Food Quality, 5521746. https://doi.org/10.1155/2021/5521746.

Grigor, J. M., Brennan, C. S., Hutchings, S. C., \& Rowlands, D. S. (2016). The sensory acceptance of fibre enriched cereal foods: a meta-analysis. International Journal of Food Science \& Technology, 51(1), 3-13. https://doi.org/10.1111/ijfs.13005.

Fukami, H., Higa, Y., Hisano, T., Asano, K., Hirata, T., Nishibe, S. (2021). A review of red yeast rice, a traditional fermented food in japan and east asia: Its characteristic ingredients and application in the maintenance and improvement of health in lipid metabolism and the circulatory system. Molecules, 26 (6). https://doi.org/10.3390/molecules26061619.

Frame, L. A., Costa, E., \& Jackson, S. A. (2020). Current explorations of nutrition and the gut microbiome: A comprehensive evaluation of the review literature. Nutrition Reviews, 78(10), 798-812. https://doi.org/10.1093/nutrit/nuz106.

Ham, Y.-K., Hwang, K.-E., Kim, H.-W., Song, D.-H., Kim, Y.-J., Choi, Y.-S., \& Kim, C.-J. (2015). Effects of fat replacement with a mixture of collagen and dietary fibre on small calibre fermented sausages. International Journal of Food Science \& Technology, 51(1), 96-104.https://doi.org/10.1111/ijfs.12960.

Hur, J. Y., \& Jang, S. C. (2015). Anticipated guilt and pleasure in a healthy food consumption context. International Journal of Hospitality Management, 48, 113123. https://doi.org/10.1016/j.ijhm.2015.04.015. 
Kamar, M., Evans, C., \& Hugh-Jones, S. (2016). Factors influencing adolescent whole grain intake: A theory-based qualitative study. Appetite, 101, 125-133. https://doi.org/10.1016/j.appet.2016.02.154.

Karthiayani, A., Udaya Ganga, M.,Ashok Kumar, C. (2021). Fibre Enrichment in Noodles using Banana Pseudo-stem (Musa paradaisiaca). Asian Journal of Dairy and Food Research. (40), 106-111. https://doi.org/10.18805/ajdfr.DR-1571.

Krittanawong, C., Isath, A., Hahn, J., Wang, Z., Fogg, S. E., Bandyopadhyay, D., Jneid H.,Virani S.S.,Tang, W. H. W. (2021). Mushroom consumption and cardiovascular health: A systematic review. American Journal of Medicine, 134(5), 637-642. https://doi.org/10.1016/j.amjmed.2020.10.035.

Ktenioudaki, A., Crofton, E., Scannell, A.G.M., Hannon, J.A., Kilcawley, K.N., Gallaghera, E. (2013). Sensory properties and aromatic composition of baked snacks containing brewer's spent grain. Journal of Cereal Science, 57, 384-390. https://doi.org/10.1016/j.jcs.2013.01.009.

Leng, G., Adan, R. A. H., Belot, M., Brunstrom, J. M., De Graaf, K., Dickson, S. L., Smeets, P. A. M. (2017). The determinants of food choice. Proceedings of the Nutrition Society, 76(3), 316-327. https://doi.org/10.1017/S002966511600286X.

Lattimer, J. M., \& Haub, M. D. (2010). Effects of dietary fibre and its components on metabolic health. $\quad$ Nutrients, $\quad$ 2(12), 1266-1289. https://doi.org/10.3390/nu2121266.

Laureati, M., Conte, A., Padalino, L., Del Nobile, M. A., \& Pagliarini, E. (2016). Effect of Fibre Information on Consumer's Expectation and Liking of Wheat Bran Enriched Pasta. Journal of Sensory Studies, 31(4), 348359.https://doi.org/10.1111/joss.12218.

Li, T., \& Dando, R. (2019). Impact of Common Food Labels on Consumer Liking in Vanilla Yogurt. Foods, 8 (11), 584. https://doi.org/10.3390/foods8110584

Lynch, K. M., Steffen, E. J., Arendt, E. K. (2016). Brewers' spent grain: a review with an emphasis on food and health. Journal of the Institute of Brewing, 122(4), 553-568. https://doi.org/10.1002/jib.363. 
Macht, M. (2008). How emotions affect eating: A five-way model. Appetite, 50(1), 111. https://doi.org/10.1016/j.appet.2007.07.00.

Makhlouf, S., Jones, S., Ye, S.-H., Sancho-Madriz, M., Burns-Whitmore, B., \& Li, Y. O. (2019). Effect of selected dietary fibre sources and addition levels on physical and cooking quality attributes of fibre-enhanced pasta. Food Quality and Safety, 3(2), 117-127. https://doi.org/10.1093/fqsafe/fyz010.

Mao, T., Huang, F., Zhu, X., Wei, D., \& Chen, L. (2021). Effects of dietary fibre on glycemic control and insulin sensitivity in patients with type 2 diabetes: A systematic review and meta-analysis. Journal of Functional Foods, 82. https://doi.org/10.1016/j.jff.2021.104500.

Maehle, N., Iversen, N., Hem, L., \& Otnes, C. (2015). Exploring consumer preferences for hedonic and utilitarian food attributes. British Food Journal, 117(12), 30393063. https://doi.org/10.1108/bfj-04-2015-0148.

Mercosur, 2012. Reglamento Técnico MERCOSUR sobre Información Nutricional Complementaria (Declaraciones de Propiedades Nutricionales). MERCOSUR/GMC/RES. $\mathrm{N}^{\circ} 01 / 12$.

Meynier, A., Chanson-Rollé, A., \& Riou, E. (2020). Main Factors Influencing Whole Grain Consumption in Children and Adults-A Narrative Review. Nutrients, 12(8), 2217.https://doi.org/10.3390/nu12082217.

Michael A. Nestrud, Herbert L. Meiselman, Silvia C. King, Larry L. Lesher, Armand V. Cardello (2016). Development of EsSense25, a shorter version of the EsSense Profile ${ }^{\circledR}$, Food Quality and Preference, 48, A, 107-117. https://doi.org/10.1016/j.foodqual.2015.08.005.

Mudgil, D., Barak, S., \& Khatkar, B. S. (2017). Cookie texture, spread ratio and sensory acceptability of cookies as a function of soluble dietary fibre, baking time and different water levels. LWT -Food Science and Technology, 80, 537542.https://doi.org/10.1016/j.lwt.2017.03.009.

Nocente, F., Taddei, F., Galassi, E., \& Gazza, L. (2019). Upcycling of brewers' spent grain by production of dry pasta with higher nutritional potential. LWT, Food Science and Technology, 114, 108421. https://doi.org/10.1016/j.lwt.2019.108421. 
Ahluwalia N, Herrick KA, Terry AL, Hughes JP., (2019). Contribution of whole grains to total grains intake among adults aged 20 and over: United States, 2013-2016. NCHS Data Brief, no 341. Hyattsville, MD: National Center for Health Statistics.

Nagy, M., Semeniuc, C.A., Socaci, S.A., Pop, C.A., Rotar, A.M., Salagean, C.D., Tofana, M. (2017). Utilization of brewer's spent grain and mushrooms in fortification of smoked sausages. Food Science and Technology, 37, 315-320. https://doi.org/10.1590/1678-457x.23816.

Nestrud, M., Meiselman, H., King, S., Lesher, L. \& Cardello, A. (2016). Development of EsSense25, a Shorter Version of the EsSense Profile®. Food Quality and Preference, 48, 107-117. https://doi.org/10.1016/j.foodqual.2015.08.005.

Ng, M.; Chaya, C.; Hort, J. (2013). Beyond liking: Comparing the measurement of emotional response using EsSense Profile and consumer defined check-all-thatapply methodologies. Food Quality and Preference, 28, 193-205. https://doi.org/10.1016/j.foodqual.2012.08.012.

Nirmala P.V.; Joye, Iris J. (2020). "Dietary Fibre from Whole Grains and Their Benefits on Metabolic Health" $\quad$ Nutrients, $12 \quad$ (10):3045. https://doi.org/10.3390/nu12103045.

Niu, B., Feng, S., Xuan, S., \& Shao, P. (2021). Moisture and caking resistant tremella fuciformis polysaccharides microcapsules with hypoglycemic activity. Food Research International, 146, https://doi.org/10.1016/j.foodres.2021.110420.

Olubunmi, I.P., Babatunde, K.S., Bolanle, O.O., Seyioba, S.O., Taiwo, L., Olukayode, O.A., \& Nwankego, E.G. (2015). Quality Evaluation of Fibre- Enriched Bread. International Journal of Nutrition and Food Sciences, 4, 503. https://doi.org/10.11648/j.ijnfs.20150404.23.

Polizer Rocha, Y.J., Lapa-Guimarães, J., de Noronha, R.L.F., Trindade, M.A. (2018). Evaluation of consumers' perception regarding frankfurter sausages with different healthiness attributes. Journal of Sensory Study, 33 (6) e1 2468. https://doi.org/10.1111/joss. 12468.

Quagliani, D., \& Felt-Gunderson, P. (2017). Closing America's Fibre Intake Gap: Communication Strategies From a Food and Fibre Summit. American Journal of Lifestyle Medicine, 11(1), 80-85. https://doi.org/10.1177/1559827615588079. 
Ranok, A., Dissamal, P., Kupradit, C., Khongla, C., Musika, S., \& Mangkalanan, S. (2021). Physicochemical properties and antioxidant activity of gluten-free riceberry-cheese cracker under simulated gastrointestinal transit. Journal of Food Science and Technology, 58(7), 2825-2833.https://doi.org/10.1007/s13197-02104978-w.

Reyes-Becerril, M., Gijón, D., Angulo, M., Vázquez-Martínez, J., López, M. G., Junco, E., Angulo, C. (2021). Composition, antioxidant capacity, intestinal, and immunobiological effects of oregano (lippia palmeri watts) in goats: Preliminary in vitro and in vivo studies. Tropical Animal Health and Production, 53(1).https://doi.org/10.1007/s11250-020-02450-z.

Santagiuliana, M., Sampedro Marigómez, I., Broers, L., Hayes, J. E., Piqueras-Fiszman, B., Scholten, E., \& Stieger, M. (2019). Exploring variability in detection thresholds of microparticles through participant characteristics. Food \& Function, 10, 5386-5397. https://doi.org/10.1039/c9fo01211g.

Selani MM, Brazaca SG, Dos Santos Dias CT, Ratnayake WS, Flores RA, Bianchini A. (2014). Characterisation and potential application of pineapple pomace in an extruded product for fibre enhancement. Food Chemistry. 15; 163:23-30. https://doi.org/10.1016/j.foodchem.2014.04.076.

Steed, H. , Macfarlane, S. (2009). Prebiotics and Probiotics Science and Technology, by Charalampopoulos, Dimitris; Rastall, Robert A., ISBN 978-0-387-79057-2. Springer-Verlag New York, p. 135.

Stephen, A. M., Champ, M. M.-J., Cloran, S. J., Fleith, M., van Lieshout, L., Mejborn, H., Burley, V. J. (2017). Dietary fibre in Europe: current state of knowledge on definitions, sources, recommendations, intakes and relationships to health. Nutrition Research Reviews, $30 \quad$ (02), 149-190. https://doi.org/10.1017/S095442241700004X.

Tomic, N., Dojnov, B., Miocinovic, J., Tomasevic, I., Smigic, N., Djekic, L. \& Vujcic, Z., (2017). "Enrichment of yoghurt with insoluble dietary fibre from triticale - A sensory perspective". LWT - Food Science and Technology 80, 59-66. https://doi.org/10.1016/j.lwt.2017.02.008. 
Tuorila, H., Hartmann, C. (2020). Consumer responses to novel and unfamiliar foods, Current Opinion in Food Science, 33, 1-8, https://doi.org/10.1016/j.cofs.2019.09.004.

Wansink, B., \& Chandon, P. (2006). Can "low-fat" nutrition labels lead to obesity? Journal of Marketing Research, 43(4), 605-617. https://doi.org/10.1509/jmkr.43.4.605.

Wegman, J., van Loon, I., Smeets, P. A. M., Cools, R., \& Aarts, E. (2018). Top-down expectation effects of food labels on motivation. NeuroImage, 173, 13-24. https://doi.org/10.1016/j.neuroimage.2018.02.011.

World Health Organization. (2020). Obesity and overweight. World Health Organization. https://www.who.int/news-room/fact-sheets/detail/obesity-and-overweight.

The WHO CVD Risk CHart Working Group (2019). World Health Organization cardiovascular disease risk charts: revised models to estimate risk in 21 global regions. The Lancet Global Health, S2214109X19303183, (19)30318-3. https://doi.org/10.1016/S2214-109X.

Yalçın, E., Kösemeci, C., Correia, P., Karademir, E., Ferreira, M., Florença, S. \& Guiné, R. (2020). Evaluation of consumer habits and knowledge about dietary fibre and fibre-rich products in Turkish population. Open Agriculture, 5(1), 375-385. https://doi.org/10.1515/opag-2020-0042.

Yang, Q., Shen, Y., Foster, T., Hort, J. (2020). Measuring consumer emotional response and acceptance to sustainable food products. Food Research international. 131, 108992. https://doi.org/10.1016/j.foodres.2020.108992.

Zanetta, L.D., Umebara, M.T.C., Costa, J.P., Takeda, D.K. \& Da Cunha, D.T. (2021), Hedonic, emotional and willingness-to-pay response to beers of a different type in Brazil. British Food Journal, 123 (1), 87-107. https://doi.org/10.1108/BFJ-022020-0137.

Zhou, Y., Dhital, S., Zhao, C., Ye, F., Chen, J. \& Zhao, G. (2020). Dietary fibre-gluten protein interaction in wheat flour dough: Analysis, consequences and proposed mechanisms.Food Hydrocolloids, 106203.https://doi.org/10.1016/j.foodhyd.2020.106203. 
Zhu, M., Zhou, F., Ouyang, J., Wang, Q., Li, Y., Wu, J., Huang, J., Liu, Z. (2021). Combined use of epigallocatechin-3-gallate (EGCG) and caffeine in low doses exhibits marked anti-obesity synergy through regulation of gut microbiota and bile acid metabolism. Food and Function, 12(9), 4105-4116. https://doi.org/10.1039/d0fo01768j. 


\title{
Influence of information in consumer response to packages of fibre enriched burgers with a by-product, brewery spent grain
}

\author{
Ana Curutchet ${ }^{1}$, Patricia Arcia ${ }^{1,2}$, Amparo Tarrega $^{3}$ \\ ${ }^{1}$ Department of Engineering, Catholic University of Uruguay, Montevideo, Uruguay \\ ${ }^{2}$ Latitud - Foundation LATU, Montevideo, Uruguay \\ ${ }^{3}$ Physical and Sensory Properties Laboratory. Instituto de Agroquímica y Tecnología de \\ Alimentos, CSIC. Avda. Agustín Escardino, 7 (46980) Paterna (Valencia) Spain
}

En preparación para enviar a Meat Science 


\begin{abstract}
Brewery spent grain (BSG) is the main brewery by-product which main use is as animal feed. The use of BSG represents an opportunity for the food industry in the reuse of byproducts since it can be considered as a functional ingredient due to its composition rich in fibre. This work studies the effect of the way of communication of BSG enrichment in the consumer response to beef burgers. To study these, different brands were considered, for each brand, three different labels were designed using their original packaging with the inclusion of the fibre addition information. Study was completed by 267 consumers measuring their purchase intention. The way fibre addition was informed to respondents had no influence in their response. Brand was the only factor studied that affected purchase intention. Cluster analysis was applied to identify segments of consumers with different patterns of preference concerning burgers brands and fibre addition communication in their labels. Four clusters were identified, in all clusters only the brand was significant and two of them are highly interested in purchasing fibre enriched burgers. To know how the best form is to inform consumers about fibre origin, respondents were asked, between different options, about how they would prefer to be stated on the product label that fibre comes from this by-product. Results seems to indicate that consumers want to include BSG in their products, want to know about the origin of the ingredient but they do not want to know deeply about the concept of by-product. Detailed information about the by-product is preferred by the consumers and should improve purchase intention.
\end{abstract}

Keywords: fibre enrichment, sustainable, by-products, brand, purchase intention. 


\section{INTRODUCTION}

Changes in lifestyle and the food industry have had a considerable impact on eating habits, leading the population to an excessive consumption of refined sugars, salt and highly caloric foods (Lobstein, Baur, \& Uauy, 2004). Current trends in the food industry and the continuous search for healthy products suggest that consumer's interest in natural and high-quality foods is increasing. (Coman et al., 2020). Consequently, the industry is committed to developing a new gastronomic offer, based on healthier foods for consumers, without distancing them from fast and tasty food solutions (Stuckler et al., 2012). Moreover, the worldwide health crisis created by the COVID-19 redirected the current consumer attitude, perception, and behavioral patterns to reduction of food waste and regarding the food products consumed (Amicarelli et al., 2021).

In this way, there is an opportunity to improve the nutritional characteristics of foods, mainly those of greater consumption, such as meat products. Meat and meat products are an important source of protein in human diets, and their consumption depends on socioeconomic factors, ethics or religious beliefs, and social habits. Burgers, due to their sensory characteristics, practicality and high content of proteins of biological value, have become widely consumed foods in many countries (Ramadhan, et al., 2011). For these, burgers represent an interesting research matrix and various studies worked to improve their nutritional profile (Angiolillo et al., 2015; Selani et al., 2016; Tátero Carvalho et al., 2019).

Currently, derivatives of vegetable origin are used, such as fruits, nuts, vegetables, herbs and spices, for the elaboration of healthier meat products, being their contribution of fibre and antioxidants the most valued for the development of said products (Mehta et al., 2019). This is a consequence of the fact that it has been reported that foods with a high proportion of dietary fibre reduce the risk of obesity, colon cancer and cardiovascular diseases (Tahreem et al., 2019, Nirmala et al., 2020).

However, it should be noted that, there is a great diversity of by-products from the food industry that are potential sources of nutrients and, if not reused, represent an environmental problem, as well as losses for industries, due to cost. associated with the treatment and transport of waste (Dhillon et al., 2013)

The concept of circular economy is an approach that seeks to respond to the challenges of current economic and productive growth, since it promotes a cyclical flow of transformation and recovery of products and services available in the market. In this way, 
the circular economy emphasizes the protection of the environment, the efficient use of resources, and their recycling (Ellen Macarthur Foundation, 2013). Although this is not a new concept, the novelty lies in the growing interest in its implementation at the government, industry, and society levels, not only to respond to global challenges, but also because it represents an opportunity for the addition of value and development. sustainable.

Brewery spent grain (BSG) is the main brewery by-product. Its annual production is estimated to be approximately 30 million tons worldwide (Ktenioudaki et al., 2015). Its main use is animal feed, compost, or as an alternative source of energy, however, the BSG that is not used is deposited in landfills, which leads to the accumulation of greenhouse gas emissions (Kitryte, Šaduikis, \& Venskutonis, 2015).

The use of BSG represents an opportunity for the food industry in the reuse of byproducts, since it can be considered as a functional ingredient due to its composition rich in fibre, protein and minerals, its low cost and its wide range availability. There is evidence of the incorporation of BSG into a wide variety of products because it represents an economical source of dietary fibre, in addition to reducing waste from food production (Stojceska et al., 2008).

The BSG has been used mainly in the preparation of bakery products (bread, cookies, cakes) where up to $10 \%$ of conventional flour could be replaced without alterations in physical properties (Arcia et al., 2018). It has also been used in the preparation of frankfurters (Özvural et al., 2009), chicken burgers (Kim et al., 2013), and beef burgers (Saraiva et al., 2019). Although the addition of BSG to food products has beneficial effects at the nutritional level, it is still necessary to investigate the factors that affect quality (texture, appearance, and taste) since they directly impact acceptability by the consumer (Mussatto S., 2014).

Consumers response to new products depends not only to the sensory properties of the product but also on the information that they perceive from the package. Label of food products contain usually information on features of the products such as origin, manufacture, nutritional (composition or claims), brand, or ingredients that influence hedonic expectations of consumers (how much they would like it). In addition, this information is useful to consumers that can also make other associations to aspects as healthiness, sustainability, convenience or naturalness that can play a relevant role in consumer decision, always depending on their personal interests and attitudes. Effective strategies to communicate information through labels can increase consumer acceptance 
of more convenient, healthy, and environmentally friendly products (Font-i-Furnols et al., 2014).

In the case of the fibre enrichment with BSG, different type of information can be interesting to consumers: nutritional (source of fibre), sustainability (from a by-product), origin of the fibre (barley fibre). It is important to know how consumers understand and use the different information to define better strategies of communications.

It should be considering that the effect of health, nutritional or organic claims on the package of food products have been shown to depend on other characteristics of product such the brand or type of product (Mahele et al., 2015; Sekhar et al., 2021).

The aim of this work was to study how packages information affected consumer response to fibre enriched meat burger with BSG.

\section{MATERIALS AND METHODS}

\section{Participants}

Study was conducted with a convenient sample of 267 voluntary respondents using an online panel. All the participants live in Uruguay and no compensation for their participation was provided. The characteristics of the participants in terms of their sociodemographic characteristics are shown in Table 1.

\section{Stimuli and experimental design}

To study the effect of fibre enrichment information on beef burgers' labels on consumer response, the labels of three different brands were used: the leader brand in Uruguay, a low-cost brand, and an artisanal brand. For each brand, three different versions were designed using their original packaging as reference in such a way that the only change made was the inclusion of the fibre addition information. All three labels presented the claim "source of fibre", two of them also included information about the fibre source, one with the affirmation "with barley fibre" and the remaining one displayed "with natural fibre from a by-product". This label also included a self-created logo showing a connection between the product and a circular economy. The third label did not include any mention about fibre source. Thus, 9 different labels were designed and shown to participants (Table 2). Figure 1 shows, as an example, some of the label designed. 
Table 1. Socio-demographic characteristics of the sample ( $N=267)$.

\begin{tabular}{l|c}
\hline \multicolumn{1}{c|}{ Variable } & $\%$ \\
\hline Gender & 52.9 \\
\hline Male & 47.1 \\
\hline Female & \\
\hline Age Group & 45.5 \\
\hline $17-29$ & 29.9 \\
\hline $30-44$ & 18.3 \\
\hline $45-60$ & 6.3 \\
\hline 61 years or older & 1.3 \\
\hline Education level & 10.7 \\
\hline Primary completed & 29.8 \\
\hline High school uncompleted & 44.4 \\
\hline High school completed & 13.8 \\
\hline Undergraduate & \\
\hline Postgraduate & 60.7 \\
\hline Number of children & 17.0 \\
\hline None & 22.3 \\
\hline 1 & \\
\hline 2 or more & 26.3 \\
\hline Household income & 73.7 \\
\hline Low/Average (less than $\$ 50.000)$ &
\end{tabular}

Table 2. Label design: experimental design considering as variable the brand and the mention about fibre source.

Brand

Leader

Low-cost

Artisanal
Other messages included in the label (apart from source of fibre)

"With barley fibre"

"With natural fibre from a by-product" and logo

"With barley fibre"

"With natural fibre from a by-product and logo"

"With barley fibre"

"With natural fibre from a by-product and logo"

Frequency of consumption of burgers was also asked on a four-point scale from 1 ("never or almost never") to 4 ("more than once a week").

The order of presentation of the images of the fibre enriched hamburgers labels was randomly varied among respondents. For each label, consumers were asked to indicate their purchase intention by a 7-point scale from 1 ("I would definitely not buy") to 7 ("I would definitely buy"). 

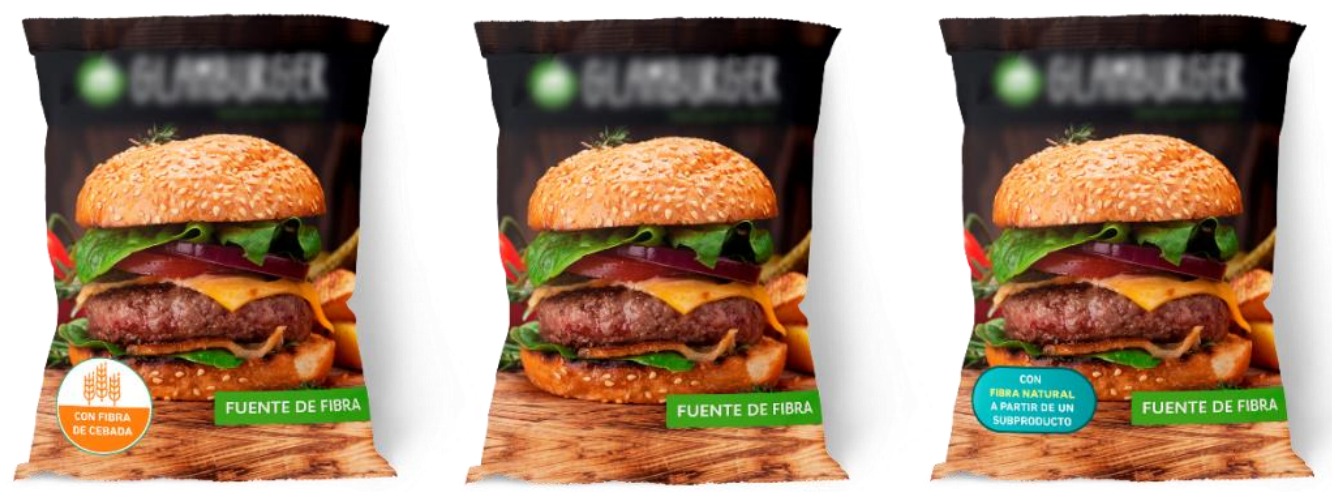

Figure 1. As an example, labels designed for the artisanal brand are shown, varying the way to mention about fibre source: a) "with barley fibre" b) without any mention c)

"with natural fibre from a by-product" and logo.

Subsequently, participants were informed about BSG origin, nutritional benefits, and impact on sustainability followed by a 7-point scale question asking if they found interesting a product enrichment in fibre using BSG (1- "I don't find it interesting" to 7"I find it very interesting").

Finally, respondents were asked to indicate how they would prefer to have the information that fibre comes from this by-product on the product label. For that, they were presented with the eight different options (Table 3) and asked to check those that applied.

Table 3. Question about fibre origin communication preference.

\section{How would you prefer it to be stated on the food label that fibre comes from this} by-product?

1. "With barley fibre"

2. "With natural fibre from a by-product"

3. "With natural fibre from a brewery by-product"

\section{4. "Reducing waste"}

5. "Environmentally friendly"

6. "Towards a circular economy"

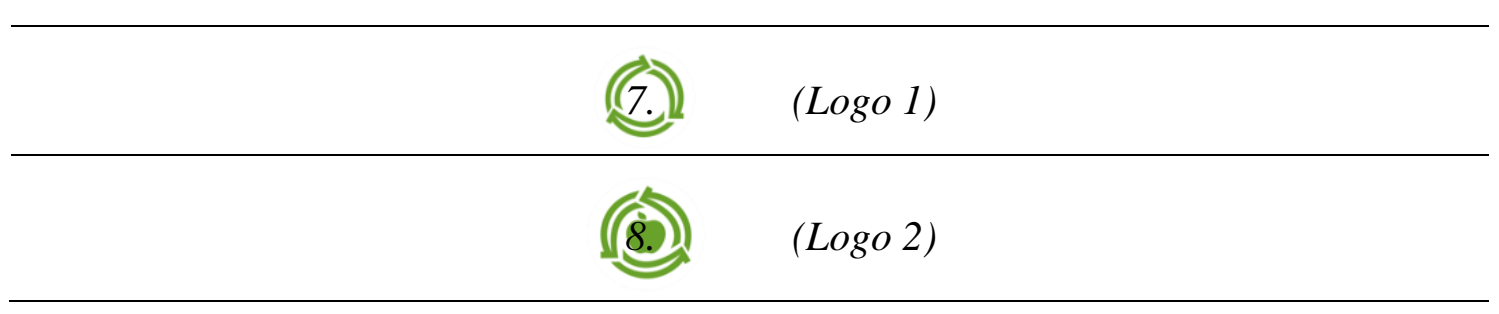




\section{Data analysis}

To study purchase intention, analysis of variance (ANOVA) of two factors, brand and message, was performed. When the effects were significant, differences were calculated using Tukey's test $(\alpha=0.05)$

With the purpose of identifying consumers groups with different patterns, hierarchical cluster analysis was performed, considering Euclidean distances and Ward's aggregation method. For each consumer group, analysis of variance (ANOVA) of two factors, brand and mention about fibre source was performed. Composition of each cluster according to consumers purchase intentions corresponding to the nine different labels presented were compared using the chi-squared test. Significant differences among proportions were determined using the Marascuilo procedure (Levy, 1975). Data analyses were performed using the software XLSTAT 2020.3.1 Version (Addinsoft, France).

\section{RESULTS AND DISCUSSION}

\section{Purchase intention and interest on BSG}

Purchase intention of consumers showed to vary among burgers packages contacting different information. ANOVA results showed that the way fibre addition was informed to consumers had no influence in their response $(\mathrm{p}=0.648)$. This may be due to a lack of fixation by participants on label's information or because the addition of fibre in hamburgers did not generate expectations. This can be also related to the fact that burgers with health benefits are not promoted locally and, consequently, there is no previous conception about the product or its consumption impact on health.

Stancu et al., 2021 study consumer understanding of health claims and the potential link between understanding and intention to buy. They report that consumers were found to attach some meanings to health claims that were benefits of the carrier product even though they were not mentioned in the health claim.

However, the brand showed to have a great impact on the purchase intention of enriched fibre burgers $(p<0,0001)$. The leader brand was preferred with a purchase intention of 4.7 followed by the artisanal with 4.3 and finally the low-cost with 2.7. Sekhar et al., 2021, reported influence of brand on the intention to purchase organic food. Their findings indicate that brand credibility is positively related to purchasing intention. Ares et al., 2018 studied consumers' perception towards product reformulation in the context of the implementation of nutritional warnings and found that brand was significant in this 
context. Preference for reformulated products without nutritional warnings was more pronounced for non-market leaders. All these shows that including sustainability information in the label, has not the same effect for all the producers.

Cluster analysis was applied to determine segments of consumers with different patterns concerning burgers and to identify those groups of consumers' willing to purchase burgers enriched with fibre.

Four clusters were identified, in all clusters brand had a significant effect and the type of information had no effect on purchase intention (Table 4). Consumers in Cluster 1 (C1) $(63.0 \%)$ do not show difference in preference between the leader and artisanal brand, but they would not buy the low-cost brand. These cluster includes mostly young consumers with high income medium frequency consumers of burgers.

Table 4 Influence of brand and kind of mention about fibre source on purchase intention of burgers. Results of Analysis of Variance F ratio and probability (p) values.

\begin{tabular}{lcccccccc}
\hline Source & \multicolumn{2}{c}{$\mathrm{C} 1(63 \%)$} & \multicolumn{2}{c}{$\mathrm{C} 2(22 \%)$} & \multicolumn{2}{c}{$\mathrm{C} 3(7 \%)$} & \multicolumn{2}{c}{$\mathrm{C} 4(8 \%)$} \\
& $\mathrm{F}$ & $\mathrm{p}$ & $\mathrm{F}$ & $\mathrm{p}$ & $\mathrm{F}$ & $\mathrm{p}$ & $\mathrm{F}$ & $\mathrm{p}$ \\
\hline Brand & 94.8 & $<0.0001$ & 393,2 & $<0.0001$ & 53.8 & $<0.0001$ & 97.7 & $<0.0001$ \\
$\begin{array}{l}\text { Mention about fibre } \\
\text { source }\end{array}$ & 2.3 & 0.10 & 0.07 & 0.93 & 1.6 & 0.21 & 0.43 & 0.65 \\
$\begin{array}{l}\text { Brand x Mention } \\
\text { about fibre source }\end{array}$ & 1.1 & 0.37 & 0.12 & 0.97 & 0.8 & 0.51 & 0.26 & 0.91 \\
\hline
\end{tabular}

Consumers in Cluster $2(22 \%)$ were only willing to by fibre enriched burger when it is in an artisanal brand and would not buy the low-cost brand burger. This group includes young people with high income that consume burgers regularly.

Cluster 3 (C3) (7\%) composed by medium age, high frequency consumers leaned towards the artisanal burgers brand, although all brands were slightly accepted by them.

Finally, Cluster 4 (C4) (8 \%) was determined by respondents that would only buy the leader brand, these consumers were mostly medium age women with low income. (Table 5)

As Figure 3 shows, Cluster 2 and Cluster 4 are highly interested in purchase enriched burgers presenting values over 5 in the 7 -point scale. These two clusters represent $30 \%$ of the totally of consumers. The Cluster 2 composed by young people, very frequent burger consumers and high income, prefer the enrichment in the artisanal brand. The Cluster 4 composed by low-income women and medium frequent consumers would buy enriched burger in the leader brand. 
The other clusters do not show a strong intention to buy enriched burgers. Anyway, there is a place for BSG enriched burgers mainly considering demographic characteristics of $\mathrm{C} 2$.

Table 5 Distribution of consumers (\%) on clusters according to gender, age, number of children and Income. Difference among proportions test, $\chi^{2}$ and probability (p) values.

\begin{tabular}{|c|c|c|c|c|c|c|c|}
\hline & & $\mathrm{C} 1$ & $\mathrm{C} 2$ & $\mathbf{C ~ 3}$ & C4 & $\chi^{2}$ & $\bar{p}$ \\
\hline \multirow{3}{*}{ Gender } & $\mathrm{M}$ & $53^{\mathrm{a}}$ & $59^{a}$ & $58^{\mathrm{a}}$ & $29^{b}$ & 24.8 & $<0.0001$ \\
\hline & $\mathrm{F}$ & $47^{b}$ & $41^{\mathrm{b}}$ & $42^{b}$ & $71^{\mathrm{a}}$ & 24.8 & $<0.0001$ \\
\hline & 17 to 29 & $50^{a}$ & $43^{a}$ & $33^{\mathrm{a}, \mathrm{b}}$ & $21^{\mathrm{b}}$ & 19.4 & $<0.0001$ \\
\hline \multirow{3}{*}{ Age } & 30 to 44 & $28^{\mathrm{a}, \mathrm{b}}$ & $37^{\mathrm{a}}$ & $17^{\mathrm{b}}$ & $36^{\mathrm{a}}$ & 12.4 & 0.006 \\
\hline & 45 to 60 & $17^{\mathrm{a}, \mathrm{b}}$ & $16^{\mathrm{b}}$ & $33^{\mathrm{a}}$ & $21^{\mathrm{a}, \mathrm{b}}$ & 10.5 & 0.015 \\
\hline & More than 60 & $5^{\mathrm{b}, \mathrm{c}}$ & $4^{\mathrm{c}}$ & $17^{\mathrm{a}, \mathrm{b}}$ & $21^{\mathrm{a}}$ & 21.9 & $<0.0001$ \\
\hline \multirow{4}{*}{$\begin{array}{l}\text { Frequency of } \\
\text { consumption }\end{array}$} & $\begin{array}{l}\text { More than once a } \\
\text { week }\end{array}$ & $3^{\mathrm{a}}$ & $44^{b}$ & $28^{\mathrm{b}}$ & $0^{\mathrm{a}}$ & 84.6 & $<0.0001$ \\
\hline & $\begin{array}{l}\text { At least once a } \\
\text { week }\end{array}$ & $19^{a}$ & $13^{\mathrm{a}}$ & $48^{\mathrm{b}}$ & $48^{\mathrm{b}}$ & 47.8 & $<0.0001$ \\
\hline & $\begin{array}{l}\text { At least once a } \\
\text { month }\end{array}$ & $51^{\mathrm{c}}$ & $29^{b}$ & $4^{\mathrm{a}}$ & $33^{\mathrm{b}, \mathrm{c}}$ & 54.2 & $<0.0001$ \\
\hline & $\begin{array}{l}\text { Less than once a } \\
\text { month }\end{array}$ & 27 & 14 & 20 & 19 & 5.1 & 0.161 \\
\hline \multirow[b]{2}{*}{ Income } & Low income & $22^{\mathrm{c}}$ & $28^{\mathrm{c}}$ & $67^{\mathrm{b}}$ & $100^{\mathrm{a}}$ & 160 & $<0.0001$ \\
\hline & High income & $78^{\mathrm{a}}$ & $72^{a}$ & $33^{b}$ & $0^{\mathrm{c}}$ & 160 & $<0.0001$ \\
\hline
\end{tabular}

Percentage values in rows followed by different letters are significantly different $(\mathrm{p} \leq 0.05)$.

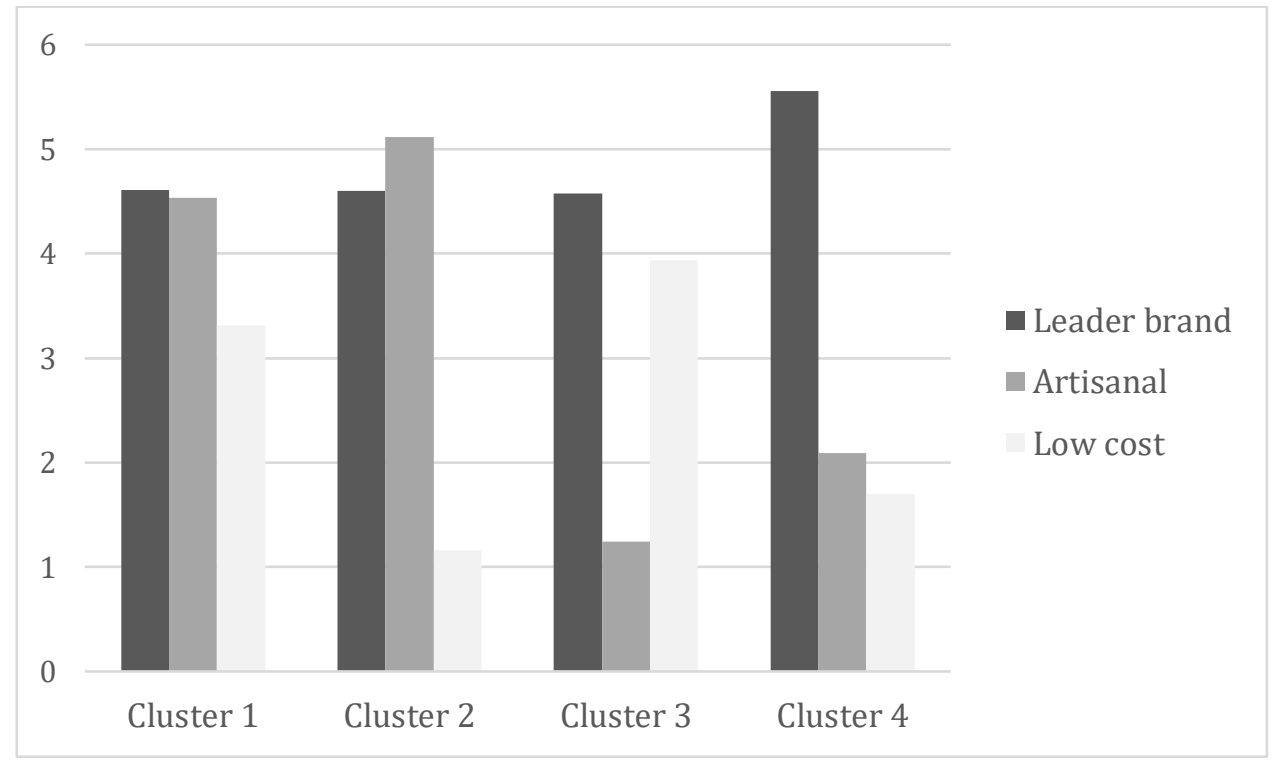

Figure 3. Average values of purchase intention of fibre enriched burgers of different brand type for the four clusters of consumers. 


\section{Fibre enrichment communication}

Once consumers were informed about BSG, $71 \%$ of consumers found very interesting (scores 6 and 7) the enrichment of food products with this by-product and they sowed to prefer some messages over others. From the options presented, the claim "with barley fibre" was selected for almost half of consumers (46.8\%) and Logo 2 (26.2\%), Figure 4.

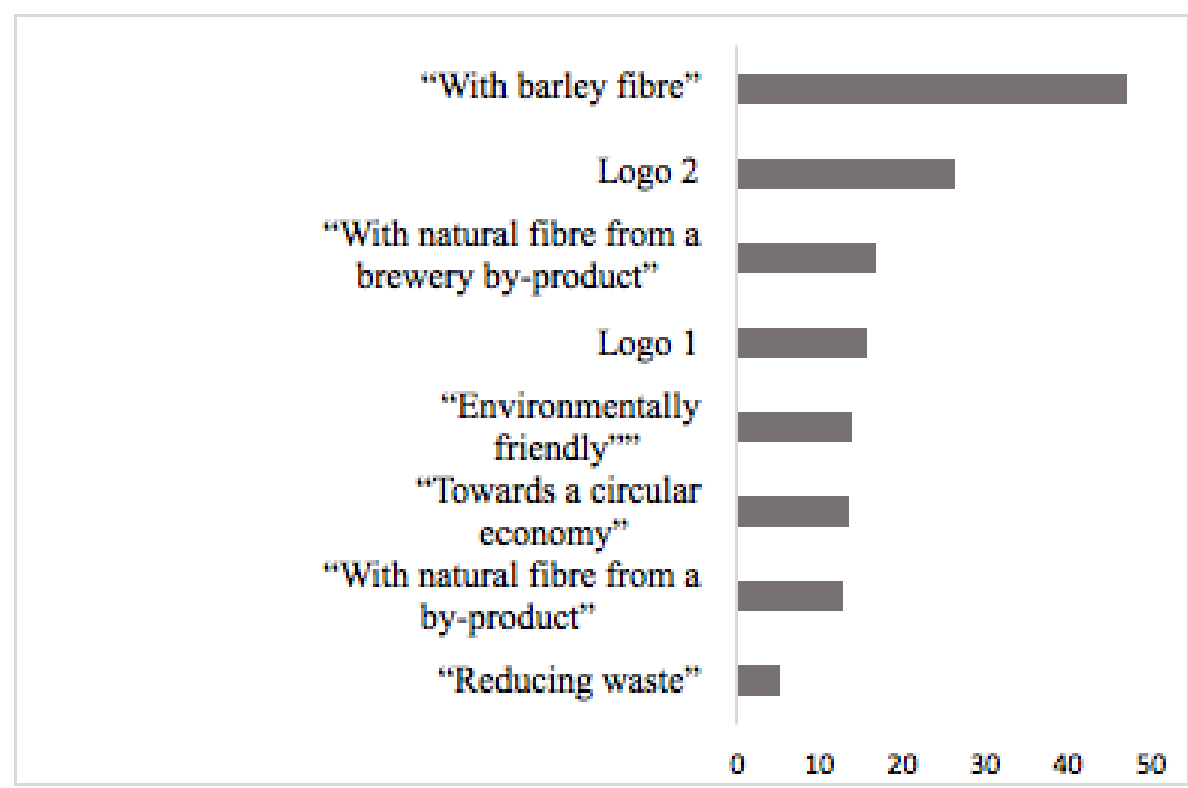

Figure 4. Frequency of mention of statements selected by consumer to be included in product label to communicate that fibre comes from this by-product.

These results indicated that when consumers received previous information about the benefits (nutritional and sustainability) that BSG generate, most consumers find interesting including BSG in products. The indication "with barley fibre" was the expression that most consumers preferred to have in these products. Curiously, only a small part of consumers showed interest on by-product, circular economy or reducing waste. This seems to agree with the findings of van Door et al., 2021 consumers respond unfavourably to sustainable new products given negative quality associations. They reported that sales of newly introduced products with a sustainability claim are lower than those of their conventional counterparts. However, these was no extended to all brands or products. They reported that more innovative new sustainable products also enjoy higher sales, and the same happens when the brand is associated with a firm's committed to ensure societal and stakeholder well-being. Pretner et al., 2021 studied consumers' willingness to pay for circular product and they found that when consumers are provided 
with information about the environmental virtues of the product, and especially when that information is verified by a third-party, consumers' WTP increases significantly.

\section{CONCLUSIONS}

Willingness to buy burgers enriched with fibre highly varied among consumers depending also on the brand of the product. Two group of consumers representing $30 \%$ of them showed to be highly interested in purchasing fibre enriched burgers when there are from the leader brand and a part of them (22\%) from also the artisanal brand.

Different messages on the fibre enrichment "with barley fibre" did not impact on the willingness of consumer to purchase the products.

Giving detailed information to consumers about the source of fibre, nutritional composition and sustainability increased the interest of consumers on products enrichment with BSG. The information they prefer to receive about that is "with barley fibre".

Other sources of information (videos, podcasts) allowing to give more detailed information than labels could be a more successful strategy to improve purchasing intention of sustainable and healthy products.

\section{ACKOWLEDGEMENTS}

Special thanks to designer Jorge Garcia for the layout of the labels.

\section{REFERENCES}

Amicarelli, V., Tricase, C., Spada, A., Bux, C. Households' Food Waste Behavior at Local Scale: A Cluster Analysis after the COVID-19 Lockdown. (2021). Sustainability, 13, 3283.

Angiolillo, L., Conte, A., \& Del Nobile, M. (2015). Technological strategies to produce functional meat burgers. LWT - Food Science and Technology, 697-703.

Arcia, P., Curutchet, A., Cozzano, S., Rodriguez, S. (2018). Bagazo de cervecería como ingrediente en el desarrollo de panificados. Impacto del rotulado en la intención de compra y aceptabilidad. Revista del laboratorio tecnologico del Uruguay, 4046.

Ares, G., Aschemann-Witzel, J., Curutchet, M. R., Antúnez, L., Machín, L., Vidal, L., Giménez, A. (2018). Product reformulation in the context of nutritional warning labels: Exploration of consumer preferences towards food concepts in three food categories. Food Research International, 107, 669-674. 
Coman, V., Teleky, B.-E.; Mitrea, L., Martău, G.A., Szabo, K.; Călinoiu, L.-F.; Vodnar, D.C. (2020). Bioactive Potential of Fruit and Vegetable Wastes. Advances in Food Nutrition Research, 91, 157-225.

Ellen Macarthur Fundation: Report. (2013). Towards the Circular Economy. Recuperado de http://www.ellenmacarthurfoundation.org/circular-economy/circulareconomy/the-circular-model-an-overview.

Font-i-Furnols, M., Guerrero, L. (2014). Consumer preference, behavior and perception about meat and meat products: An overview. Meat Science, 98, 3, 361-371.

Kim, H.-W., Hwang, K.-E., Song, D.-H., Lee, S.-Y., Choi, M.-S., Lim, Y.-B., ... Kim, C.-J. (2013). Effects of Dietary Fibre Extracts from Brewer's Spent Grain on Quality Characteristics of Chicken Patties Cooked in Convective Oven. Korean Journal for Food Science of Animal Resources, 33(1), 45-52.

Kitryte, V., Šaduikis, A., Venskutonis, P. R. (2015). Assessment of antioxidant capacity of brewer's spent grain and its supercritical carbon dioxide extract as sources of valuable dietary ingredients. Journal of Food Engineering, 18-24.

Ktenioudaki, A., Gallagher, E. (2012). Recent advances in the development of highfibre baked products. Trends in Food Science \& Technology, 28(1), 4-14.

Lobstein, T., Baur, L. and Uauy, R. (2004), Obesity in children and young people: a crisis in public health. Obesity Reviews, 5: 4-85.

Levy, K. J. (1975). Large-sample pair-wise comparisons involving correlations, proportions, or variances. Psychological Bulletin, 82(2), 174-176.

Maehle, N., Iversen, N., Hem, L., Otnes, C. (2015). Exploring consumer preferences for hedonic and utilitarian food attributes. British Food Journal, 117(12), 3039-3063.

Mehta, N., Chatli, M. K., Kumar, P., Malav, O. P., Verma, A. K., Kumar, Y., \& Kumar, D. (2019). Development of dietary fibre-rich meat products: Technological advancements and functional significance.

Mussatto, S.I., 2014. Brewer's spent grain: a valuable feedstock for industrial applications. Journal of Science Food and Agriculture., 94, pp.1264-127.

Nirmala, P., Joye, P.V., Iris, J. (2020). Dietary Fibre from Whole Grains and Their Benefits on Metabolic Health. Nutrients, 12, 10: 3045.

Özvural, E., Vural, H., Gökbulut, İ., Özboy-Özbaş, Ö. (2009). Utilization of brewer's spent grain in the production of Frankfurters. International Journal of Food Science and Technology.

Pretner, G., Darnall, N., Testa, F., \& Iraldo, F. (2021). Are consumers willing to pay for circular products? the role of recycled and second-hand attributes, messaging, and third-party certification. Resources, Conservation and Recycling, 175.

Ramadhan, K., Huda, N., Ahmad, R. (2011). Physicochemical characteristics and sensory properties of selected Malaysian commercial chicken burgers. International Food Research Journal, 1349-4357.

Rozin, P. (2007). Food choice: An introduction. In Understanding Consumers of Food Products. Frewer, L., van Trijp, Eds.; Elsevier: Amsterdam, The Netherlands. 329. 
Saraiva, B.R., Agustinho, B.C., Pelaes Vital, A.C., Staub, L., \& Matumoto P. (2019). Effect of brewing waste (malt bagasse) addition on the physicochemical properties of hamburgers. Journal of Food Processing and Preservation, 43(11).

Sekhar, C., Krishna, S., Kayal, G.G. \& Rana, N.P. (2021). Does brand credibility matter? The case of organic food products. British Food Journal, Vol. ahead-of-print No. ahead-of-print

Selani, M. M., Shirado, G. A., Margiotta, G. B., Saldaña, E., Spada, F. P., Piedade, S. M., y otros. (2016). Effects of pineapple byproduct and canola oil as fat replacers on physicochemical and sensory qualities of low-fat beef burger. Meat Science, 6976.

Stojceska, V., Ainsworth, P., Plunkett, A., Ibanoglu, S. (2008). The recycling of brewer's processing by-product into ready-to-eat snacks using extrusion technology. Journal of Cereal Science 47, 469-479.

Stancu, V., Lähteenmäki, L., Grunert, K. G. (2021). The role of time constraints in consumer understanding of health claims. Food Quality and Preference, 94.

Stuckler, D., Nestle, M. (2012). Big Food, Food Systems, and Global Health. PLoS Med 9(6): e1001242.

Tahreem, K., Entesar, H., Omeera, A., Bushra, P., \& Zraa, A. (2019). A review on functional ingredients in red meat products. Biomedical Informatics, 15(5): 358363.

Tátero Carvalho, L., Alves Piresi, M., Baldin, J.C. Sichetti, P. E., Leandro de Carvalho, F.A., Rodrigues, I., Polizer, Y.J., Malagoli de Mello, J.L., Trindade, M.A. (2019). Partial replacement of meat and fat with hydrated wheat fibre in beef burgers decreases caloric value without reducing the feeling of satiety after consumption. Meat Science. 147, 53-59.

van Doorn, J., Risselada, H., Verhoef, P. C. (2021). Does sustainability sell? the impact of sustainability claims on the success of national brands' new product introductions. Journal of Business Research, 137, 182-193. 
Uso del subproducto de la producción de cerveza como fuente de fibra 


\section{Discusión general de los resultados}


La revalorización de los subproductos que la industria genera durante el procesado de alimentos y la mejora en el perfil nutricional de productos que además gusten a los consumidores, favoreciendo una dieta más saludable, son en la actualidad dos grandes retos para la industria alimentaria. Como aporte a la solución conjunta de estos grandes problemas, esta tesis busca generar conocimiento sobre el impacto que tiene en la respuesta del consumidor el enriquecimiento en fibra de alimentos mediante el uso de subproductos teniendo en cuenta los factores del producto tanto intrínsecos (sensoriales) como extrínsecos (información) y los del propio consumidor (actitudes individuales).

Para ello se abordan tres aspectos: La percepción del consumidor sobre los alimentos con distintos beneficios nutricionales. El impacto de la incorporación de diferentes subproductos de la industria alimentaria en la aceptabilidad de los consumidores. Y finalmente, el efecto de la información en la aceptabilidad de productos enriquecidos en fibra a base de subproductos.

\section{PERCEPCIÓN DEL CONSUMIDOR DE ALIMENTOS CON DISTINTOS BENEFICIOS NUTRICIONALES EN QUESO Y SU EVOLUCIÓN EN LA ÚLTIMA DÉCADA}

Los consumidores en general perciben los productos con beneficios nutricionales como distintos al original y su decisión de comprar o tomar estos productos depende en primer lugar de lo interesante que le resulte el beneficio nutricional pero también de la expectativa de aceptabilidad que tiene acerca del producto. Las expectativas se generan en base a experiencias previas con el mismo producto, marca, beneficio o característica o en base a asociaciones que el consumidor hace a otros productos. Es por ello que las expectativas de un consumidor respecto a un nuevo producto o una nueva característica en el producto pueden cambiar con el tiempo y que la exposición o el contacto repetido con el producto puede hacer que la expectativa mejore o empeore. En esta tesis se ha estudiado la respuesta de los consumidores uruguayos a quesos con distintos beneficios nutricionales (bajo en grasa, reducido en sal, enriquecido en fibra y con probióticos) y cómo ha cambiado a lo largo de la última década. El estudio cuantitativo basado en análisis conjunto muestra que la respuesta de los consumidores a los beneficios nutricionales en quesos depende del tipo de queso y del beneficio nutricional. En general el interés en tener beneficios nutricionales es menor en el queso de tipo tradicional (danbo) que en el queso untable. En el queso de tipo tradicional existe en general un 
mayor interés en el producto normal que en el producto con beneficios. Sin embargo, en el caso del queso untable, la opción "bajo en grasa" resulta a los consumidores en general tan interesante como el normal y para alguno de los grupos de consumidores algunos beneficios como "bajo en grasa" o "bajo en sal" resulta más interesante que el normal. Como otros trabajos muestran, la predisposición de los consumidores a aceptar un cambio en el producto depende de la categoría de producto. En general los consumidores admiten mejor aquellas mejoras nutricionales que sean "coherentes" con el producto o a las que esté acostumbrado y rechazan las mejoras nutricionales en productos hedónicos y tradicionales (Maehle et al., 2015, Stancu et al., 2021).

Respecto a la influencia del tiempo en la respuesta de los consumidores, en 2010 los consumidores mostraron en general estar poco interesados en quesos con beneficios nutricionales. Sólo en el caso del queso untable, el análisis de los distintos patrones de respuesta de los consumidores, mostró que para el 20\% de consumidores, el contenido reducido en grasa o en sal fueron opciones más atractivas que el producto normal. Diez años después, se observa un incremento en el interés de los consumidores uruguayos por una dieta que sea saludable, ya que usando la misma escala (Roininen et al., 1999; versión en español de Villegas et al., 2008) se pasó de un nivel de interés medio a alto entre 20102018. Sin embargo, no se observó en general un mayor interés en quesos con beneficios nutricionales. Aunque, aparece un grupo (20\% de los consumidores, principalmente mujeres) para las que el queso enriquecido en fibra resulta más interesante que el queso normal.

Estos resultados reflejan que en el sector de quesos existe una cierta reticencia de los consumidores a aceptar mejoras nutricionales en quesos y en especial en los de tipo tradicional, para los que el cambio detectado es un mayor interés en la elaboración artesanal.

El queso untable es una mejor alternativa para el desarrollo de alimentos funcionales, donde además del interés en productos bajos en grasa, destaca que el interés de una parte de consumidores, preferentemente formado por mujeres, parece dirigirse al enriquecimiento en fibra y bifidus. 


\section{IMPACTO DEL ENRIQUECIMIENTO EN FIBRA A BASE DE SUBPRODUCTOS EN LA EXPECTATIVA Y LA ACEPTABILIDAD DEL CONSUMIDOR DE DISTINTOS ALIMENTOS}

La industria de procesamiento de frutas, vino y cerveza son de las industrias alimentarias que generan la mayor cantidad de residuos biológicos en el planeta (Comunian et al., 2021). Estos residuos a su vez tienen una composición nutricional que los hace interesantes como ingredientes funcionales. Se ha trabajado en esta tesis en el desarrollo de distintos productos enriquecidos en fibra mediante el uso de subproductos de la industria de elaboración de jugo de arándanos, jugo de manzana y cerveza.

\section{SUBPRODUCTO DE PRODUCCIÓN DE JUGO DE ARÁNDANOS}

En primer lugar, se trabajó con la revalorización del descarte de la producción de jugo de arándanos, mediante la transformación en harina y su uso como ingrediente funcional en la elaboración de galletas que se puedan etiquetar como fuente de fibra. En esta tesis se utilizó una harina obtenida mediante secado y molienda del subproducto de jugo de arándano. Esta harina contiene un 26\% de fibra y $61 \%$ de carbohidratos (Tagliani et al., 2019). Los ensayos de reformulación y desarrollo del producto mostraron que esta harina puede incorporarse al 38\% en la formulación de galletas, reemplazando harina de trigo, para obtener un producto con un $15 \%$ en fibra que se puede etiquetar como fuente de fibra.

Se estudió la respuesta de los consumidores a galletas enriquecidas en fibra y una control (sin enriquecer) tanto a las características del producto desarrollado (Figura 1) como a las de la etiqueta que incluía la información "fuente de fibra" y "con antioxidantes naturales" (Figura 2). La expectativa de los consumidores al observar la etiqueta de las galletas enriquecidas en fibra fue buena, con un valor de aceptabilidad esperada alto y similar al generado por la etiqueta de una galleta normal usada como control. Sin embargo, cuando los consumidores probaron la galleta enriquecida con fibra de arándano, el nivel de agrado fue menor al que esperaban los consumidores indicando que las características del producto no gustaron al consumidor. Cuando los consumidores probaron la galleta y tienen también la etiqueta, la aceptabilidad incrementó ligeramente pero no de forma significativa, indicando que aunque los consumidores estén interesados en este tipo de 
productos y tienen una buena expectativa, no están dispuestos a comprometer aspectos hedónicos por atributos saludables.
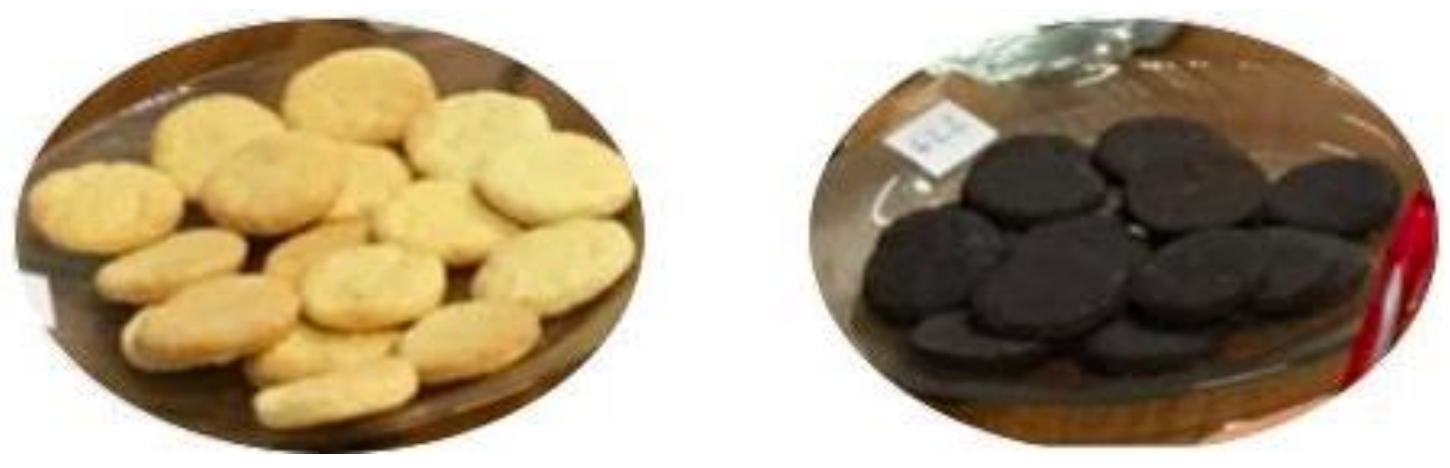

Figura 1. Galleta control (izquierda) y galleta fuente de fibra (derecha).

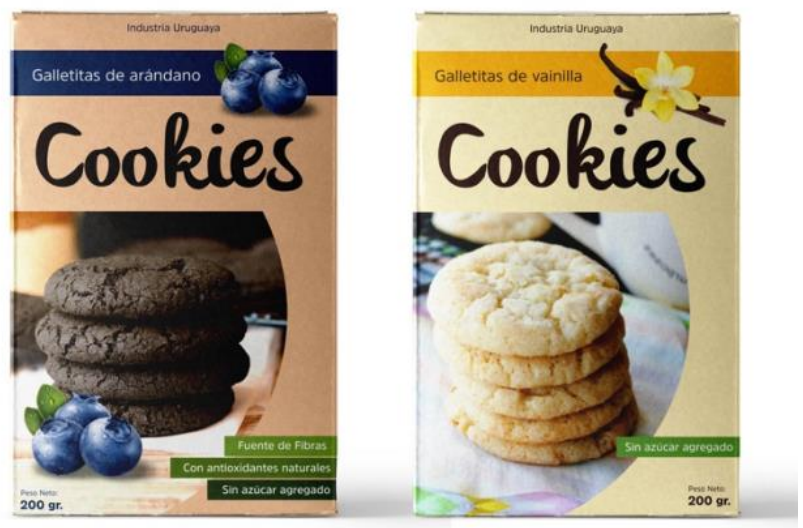

Figura 2. Etiquetas utilizadas para la evaluación de las galletas con información.

Para conocer los aspectos sensoriales críticos que produce la incorporación de harina de arándanos y que afectan a la aceptabilidad de la galleta de los consumidores se realizó una investigación cualitativa con un grupo de discusión en el que participaron un número reducido de consumidores de galletas. Los consumidores confirmaron que, en las galletas, que son productos que consumen por placer, aunque les resulten interesantes las mejoras nutricionales, éstas no son suficientes si el producto no satisface las expectativas hedónicas esperadas. Los atributos que los consumidores esperan en general para una galleta es que sean crocantes, sabrosas y finas. Los atributos con los que describieron la galleta con fibra fueron blanda, sabrosa, ácida y con un color extraño.

Se puede concluir que la harina de arándanos presenta potencial para ser usada como ingrediente en el sector de galletería ya que los consumidores muestran buenas expectativas por galletas enriquecidas con fibra, pero las características sensoriales del 
producto deben de estar alineadas con los atributos intrínsecos esperados que en el caso de las galletas que son ser finas, crocantes y de sabor intenso.

\section{SUBPRODUCTO DE PRODUCCIÓN DE JUGO DE MANZANA}

La pulpa de manzana es el residuo de la producción de jugo de manzana y es otro subproducto de volumen importante a nivel mundial. Parte de la investigación se ha centrado en la caracterización de la harina obtenida a partir de la pulpa de manzana, su aplicación para enriquecer un producto de bollería y cómo percibe el consumidor el nuevo producto. La harina obtenida mediante secado y molido del descarte de la producción de jugo de manzana tiene como característica nutricional destacada un $38 \%$ de fibra alimentaria y un $47 \%$ de carbohidratos provenientes de la fruta. Se decidió incorporarlo en un producto de bollería como es la premezcla para preparar bizcochuelo, que es un producto habitual en el mercado uruguayo. El desarrollo mostró que la harina de pulpa de manzana puede incorporarse al 23\%, remplazando harina de trigo y sacarosa en una premezcla para preparar un bizcochuelo con un $6,3 \%$ de fibra alimentaria y un $17 \%$ menos de carbohidratos que un bizcochuelo comercial. Se evaluó la aceptabilidad de los consumidores del bizcochuelo elaborado con el preparado enriquecido en fibra de manzana y el impacto de etiqueta que incluía la información de la etiqueta "fuente de fibra" y "con fibra de manzana" (Figura 3). Como producto control se utilizó en este caso un bizcochuelo comercial del mercado (seleccionado en un ensayo previo).
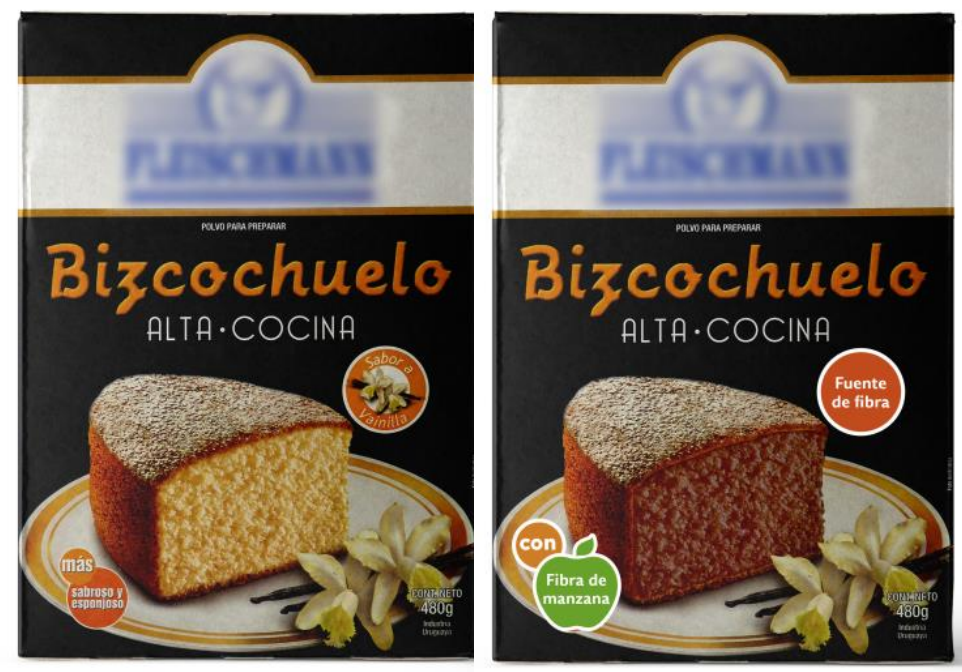

Figura 3. Etiquetas utilizadas para la evaluación de los bizcochuelos. 
En la evaluación de los bizcochuelos en ciego la aceptabilidad del bizcochuelo enriquecido en fibra fue significativamente menor que el del control. Esto puede ser por la presencia de la fibra que se puede percibir visualmente (Figura 4) o porque el bizcochuelo normal tiene mayor contenido de azúcar, aspectos que usualmente impactan en la aceptabilidad.
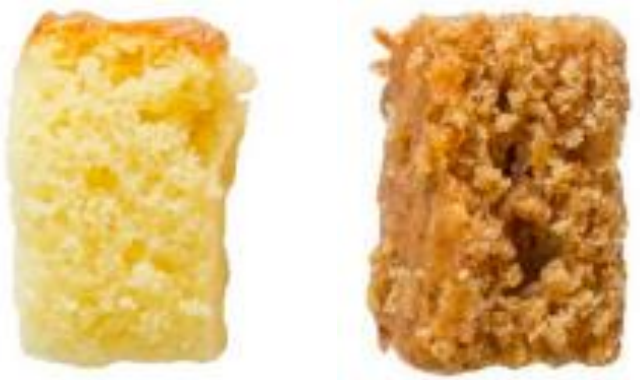

Figura 4. Bizcochuelo desarrollada a partir de premezcla regular (izquierda) y premezcla enriquecida (derecha).

Sin embargo, cuando los consumidores probaron los bizcochuelos teniendo la etiqueta, la aceptabilidad del producto enriquecido en fibra aumentó significativamente mientras que la del bizcochuelo control no varió. Esto indica que el conocimiento de que es fuente de fibra y que proviene de la manzana mejora la aceptabilidad del producto bien porque dichas características resultan interesantes al consumidor o bien porque la información del origen hace que el consumidor pueda reconocer ciertos atributos sensoriales como el color y sabor que encuentren ajenos al producto cuando no tiene dicha información. Los consumidores también describieron las características relevantes en cada uno de los bizcochuelos en relación con las de su bizcochuelo ideal utilizando una pregunta "Check all that apply "(CATA). Las características esperadas en el bizcochuelo ideal para la mayoría de los consumidores son: casero, dulce, húmedo, suave, esponjoso y saludable. El bizcochuelo enriquecido en fibra fue descrito como casero y saludable con más frecuencia que el bizcochuelo normal pero también como fibroso, con sabor a fruta y sabor extraño, mientras que el bizcochuelo normal fue descrito con más frecuencia como dulce, suave y esponjoso.

El análisis de conglomerados permitió determinar los grupos de consumidores con distinto patrón de respuesta frente al bizcochuelo enriquecido en fibra de manzana. Un grupo de consumidores (30\%) formado principalmente por personas de mayor edad, prefieren el bizcochuelo enriquecido con fibra al normal porque lo consideraban saludable, les gusta y les proporciona la fibra que necesitaban en su dieta. Los otros dos 
grupos formados por consumidores más jóvenes, prefieren el bizcochuelo normal. En uno de ellos, los consumidores (40\%) también se muestran interesados en el bizcochuelo enriquecido en fibra, principalmente porque también les gusta. Mientras que el grupo de consumidores que rechaza el bizcochuelo enriquecido en fibra representa el 30\% de los consumidores y es principalmente porque no les gustaba o por ser distinto a su bizcochuelo habitual.

En resumen, la estrategia del uso de la harina de pulpa de manzana para enriquecer en fibra productos de bollería tiene un lugar dentro del mercado uruguayo dado que existe una parte relevante de consumidores que lo elegirían por ser saludable y a los que le gusta el producto. En este estudio los consumidores conocían que el producto contenía fibra de manzana pero no disponían de información sobre su obtención a partir de un subproducto y su carácter sustentable. Kaczorowska et al., 2019 encontraron que la información sobre sustentabilidad en las etiquetas puede influir en el comportamiento del consumidor ya que perciben diferentes beneficios al comprar el producto. En este sentido se debe explorar si la inclusión de sustentabilidad en la información que se le ofrece al consumidor puede aumentar la aceptación e interés de los consumidores del bizcochuelo enriquecido.

\section{SUBPRODUCTO DE PRODUCCIÓN DE CERVEZA: BREWERY SPENT GRAIN}

Finalmente, se investigó la revalorización de uno de los residuos más importantes de la industria cervecera, conocido como BSG (por las siglas en inglés brewery spent grain). Durante el proceso de elaboración de cerveza, los cereales ya malteados se maceran para extraer los azúcares del endospermo de los granos y producir el mosto dulce. Éste es luego hervido con lúpulos y fermentado para dar lugar a la cerveza. Sin embargo, mientras el mosto continúa con este proceso, los remanentes de la cebada malteada se convierten en un residuo. Este residuo es conocido como bagazo de cerveza, comúnmente abreviado por su siglas en inglés BSG (Brewery Spent Grain).

Éste contiene por lo tanto componentes de la cebada, lúpulos, residuos de levadura y adjuntos cerveceros usados en la elaboración de cerveza. Su composición varía de acuerdo a la receta de cerveza elaborada, pero en general en materia seca contiene: 30$50 \%$ de fibra alimentaria, $19-30 \%$ de proteínas, $10 \%$ lípidos y 2-5\% de cenizas (Lynch et al., 2016). 
En este trabajo se obtuvo el BSG de una cervecería líder del mercado en Uruguay, que se secó y molió para obtener una harina en la que destaca el contenido de fibra (45,5\%) y de proteína $(24,9 \%)$. En este caso se estudió su incorporación en tres tipos de productos: pan, pasta y leche chocolatada. Se desarrollaron productos con la cantidad de BSG necesaria ( $8,3 \%$ en el pan, $2,8 \%$ en la pasta y $0,3 \%$ en la leche chocolatada). Se evaluaron los cambios sensoriales que perciben los consumidores y cómo influyen en la aceptabilidad, la intención de compra y las sensaciones que transmite al consumidor, comparados con el producto control (Figura 5).
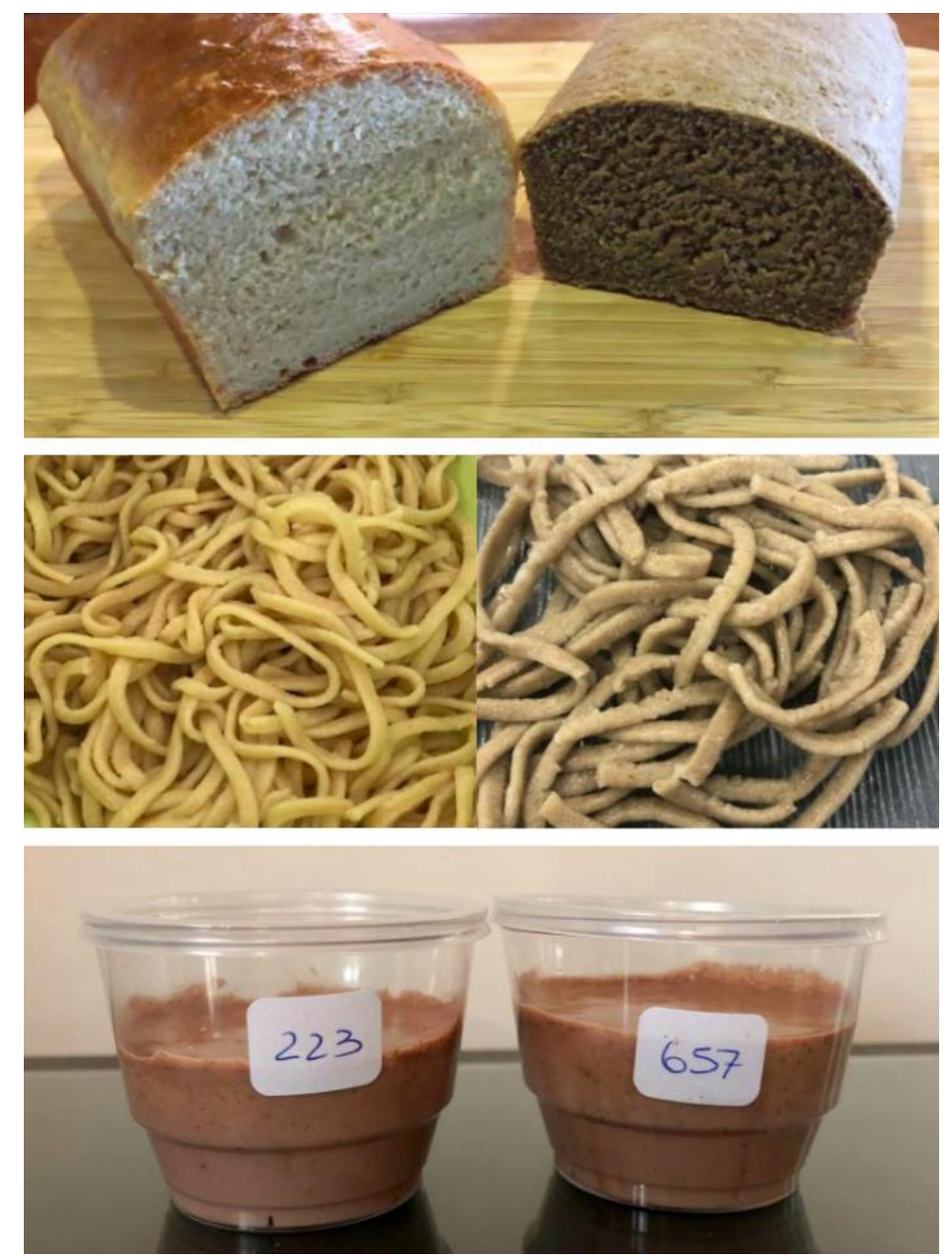

Figura 5. Panes, pasta y leche chocolatada regular (izquierda) y enriquecidas con BSG (derecha).

En el caso del pan enriquecido en fibra además de presentar un color oscuro fue descrito con mayor frecuencia como fibroso, compacto y seco que el pan normal aunque ambos fueron descritos como naturales y húmedos. La aceptabilidad del pan enriquecido fue menor pero sin embargo la intención de compra fue similar a la del producto control. Las 
razones para comprar el pan con fibra de los consumidores fueron ser saludable, incluir fibra en su dieta y que les gustaba. Esto indica que a pesar de no tener información acerca del contenido en fibra, el cambio en las características sensoriales provocó asociaciones con el contenido nutricional y lo saludable que es el producto, además tuvieron un impacto en la respuesta emocional ya que disminuyó la sensación de culpabilidad e incrementó la sensación de calma pero también la de aburrimiento.

La incorporación de BSG también causó cambios sensoriales en la pasta, descrita con mayor frecuencia como natural, fibrosa, granulosa, oscura, arenosa y con sabor extraño que la pasta normal descrita como suave, homogénea, uniforme y flexible. A pesar de las diferencias sensoriales, la aceptabilidad y la intención de compra de la pasta enriquecida fueron similares a las de la pasta normal. Los motivos que destacan para comprar pasta con fibra (aunque no tenían esta información) es porque les gusta, por ser saludable y para incluir fibra en su dieta mientras que la pasta normal la compran simplemente porque les gusta. Del mismo modo el cambio en las características sensoriales del producto afectó a la respuesta emocional ya que la pasta enriquecida en fibra les hizo sentir menos culpables, libres, osados, felices y activos pero más calmados, contenidos, encantados y aburrido que la pasta normal.

Con lo cual para estos dos productos se puede concluir que si bien las características sensoriales se vieron fuertemente afectadas por la incorporación de BSG, también llevaron al consumidor a asociaciones de producto más saludable y con mayor contenido en fibra que les llevó a querer comprarla y también a una distinta respuesta emocional.

Para la leche chocolatada la respuesta de los consumidores fue bien distinta a los casos anteriores. La leche enriquecida en fibra descrita con más frecuencia como arenosa, artificial con retrogusto y sabor extraño que la leche normal presentó menor grado de aceptabilidad e intención de compra. En lo que respecta a las emociones en este caso solo 3 términos mostraron diferencia significativa entre las dos versiones. Los participantes se sintieron más calmados y tranquilos al probar la leche enriquecida pero menos controlados que con la leche control.

Este trabajo indica que en el desarrollo de productos enriquecidos en fibra, es importante identificar los cambios sensoriales del producto que transmiten al consumidor o confirman la percepción del producto saludable y que son la que hay que mantener. Aquellas que sólo disminuyen la aceptabilidad, son las que hay que tratar de mejorar en la optimización de las formulaciones. 
Finalmente se estudió el efecto de la información de la etiqueta en la respuesta del consumidor frente a hamburguesas enriquecidas con BSG. Se consideraron tres posible formas de informar sobre la inclusión del BSG en la formula: 1) solo fuente de fibra, 2) fuente de fibra y una frase que hiciera referencia al origen "con fibra de cebada" y 3) fuente de fibra y una frase que hiciera referencia a la sustentabilidad del producto. Se estudió el efecto de esto en 3 marcas, una líder del mercado, una artesanal y una de bajo costo. Se diseñaron las tres etiquetas de cada marca respetando las características que tiene cada una de ellas en el mercado (Figura 6).
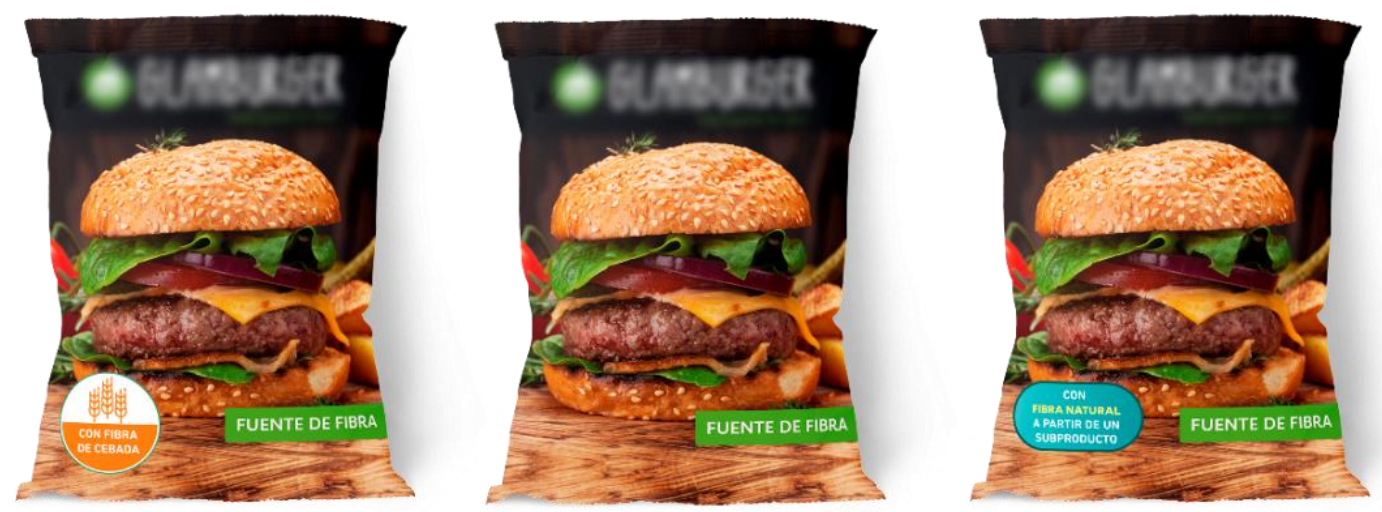

Figura 6. Etiquetas usadas para evaluar el efecto de la información en hamburguesas enriquecidas con BSG.

La intención de compra de los consumidores varió entre las etiquetas de hamburguesa enriquecidas en fibra dependiendo principalmente de la marca. El tipo de información con la que se informó del enriquecimiento en fibra no resulto en ningún cambio.

El estudio de segmentación, mostró que la intención de compra de hamburguesas enriquecidas en BSG varió entre los consumidores dependiendo de la marca. Dos grupos de consumidores que representaban un $30 \%$ del total mostraron interés en comprar hamburguesas enriquecidas en fibra. Una parte de estos le interesaría si fuera comercializada con la marca líder y otra parte también la aceptaría comercializada por la artesanal también.

Cuando al consumidor se le dio información detallada del origen del BSG, su aporte nutricional y su impacto en la sustentabilidad una gran parte de consumidores $(70 \%)$ indican que les interesaría comprar alimentos con BSG, y prefirieron en este caso que en la etiqueta se hiciera referencia a su presencia mediante la frase "con fibra de cebada". 
Por lo tanto para que el uso de subproductos sea valorado por los consumidores es relevante que éste tenga información detallada del origen y las ventajas del mismo, y no es suficiente con la que se puede incluir en la etiqueta. Otros medios que permitan difundir con mayor detalle la información como videos, podcast, redes sociales podrían ser una estrategia exitosa para mejorar la intención de compra de productos sustentables y saludables.

\section{REFERENCIAS}

Comunian, T.A., Silva, M.P., Souza, C.J.F. (2021). The use of food by-products as a novel for functional foods: Their use as ingredients and for the encapsulation process, Trends in Food Science \& Technology, 108, 269-280.

Kaczorowska, J., Rejman, K., Halicka, E., Szczebylo, A., Gorska-Warsewicz. (2019). H. Impact of food sustainability labels on the perceived product value and price expectations of urban consumers. Sustainability, 11 (24).

Lynch, K. M., Steffen, E. J., Arendt, E. K. (2016). Brewers' spent grain: a review with an emphasis on food and health. Journal of the Institute of Brewing, 122 (4), 553568.

Maehle, N., Iversen, N., Hem, L., Otnes, C. (2015). Exploring consumer preferences for hedonic and utilitarian food attributes. British Food Journal, 117(12), 3039-3063.

Muñoz, A.M., Civille, G.V., Carr, B.T. (1992). Introduction. In: Muñoz AM (ed.) Sensory Evaluation in Quality Control. Boston: Springer US, 1-22.

Roininen, K., Lähteenmäki, L., Tuorila, H. (1999). Quantification of Consumer Attitudes to Health and Hedonic Characteristics of Foods. Appetite, 33, 71-88.

Stancu, V., Lähteenmäki, L., Grunert, K. G. (2021). The role of time constraints in consumer understanding of health claims. Food Quality and Preference, 94.

Tagliani, C., Perez, C., Curutchet, A., Arcia, P., Cozzano, S. (2019). Blueberry pomace, valorization of an industry by-product source of fibre with antioxidant capacity. Food Science and Technology, 39(3), 644-651.

Villegas, B. Carbonell, I. Costell, E. (2008). Effects of product information and consumer attitudes on responses to milk and soybean vanilla beverages. Journal of the Science of Food and Agriculture, 88, 2426-2434. 
Discusión general de los resultados 


\section{Conclusiones}


Las siguientes son las conclusiones del trabajo presentado.

- En el sector de los quesos, la introducción de productos con beneficios saludables se enfrenta al bajo interés de los consumidores en especial en los quesos de tipo semi-blando como el Danbo. En queso untable, sólo la reducción en grasa es interesante para los consumidores. A pesar de que en la última década ha aumentado el interés en la dieta saludable de los consumidores, no ha cambiado así su interés por quesos con otros beneficios como pueda ser la reducción en sal y el enriquecimiento en fibra o probióticos.

- Los subproductos de la elaboración de la industria productora de jugo de arándanos, jugo de manzana y cerveza pueden incorporarse en la elaboración de distintos productos como galletas, bizcochuelos, pan y pasta para desarrollar productos "fuente de fibra". La respuesta del consumidor a estos nuevos productos enriquecidos en fibra es compleja y depende del producto, de los cambios sensoriales y del tipo de información proporcionada.

- Los consumidores uruguayos presentan buenas expectativas respecto a las galletas enriquecidas en fibra. El subproducto de la elaboración de jugo de arándanos, rico en fibra y con actividad antioxidante tiene potencial como ingrediente en el desarrollo de productos de galletería "fuente de fibra" si bien el éxito del producto está condicionado a la mejora de las características sensoriales que el consumidor espera en el producto principalmente el carácter crocante y poco espesor.

- La harina obtenida a partir del subproducto de la elaboración de jugo de manzana es una buena estrategia para el enriquecimiento de fibra de productos de bollería. Los consumidores mejoran su grado de aceptabilidad con la información de que el producto es fuente de fibra y que ésta proviene de la manzana. Un 30\% de los consumidores son los que prefieren y están interesados en el producto enriquecido en fibra porque les gusta y les parece saludable. 
- La incorporación de la harina obtenida del subproducto de la industria cervecera a distintas categorías de producto como son el pan, la pasta y leche chocolatada afecta de forma distinta a la aceptación del consumidor. Las características sensoriales del producto enriquecido que hacen reconocible el enriquecimiento en fibra mejoran la aceptabilidad y las sensaciones que transmite al consumidor.

- La intención de compra de los consumidores uruguayos respecto a hamburguesas enriquecidas en fibra, no se ve afectada cuando además de la declaración "fuente de fibra" se incluye información sobre el origen de la fibra (fibra de cebada) o la sustentabilidad, pero sí está condicionada a la marca. Los consumidores interesados en hamburguesas enriquecidas en fibra (30\%), las comprarían sólo si son de la marca líder o la marca artesanal.

En global esta tesis muestra que el uso de subproductos de la industria alimentaria como ingredientes para enriquecer productos es una estrategia cuya viabilidad depende del producto. Para desarrollar con éxito estos productos, es importante conocer el impacto de las modificaciones sensoriales en el consumidor y determinar estrategias efectivas para informar enriquecimiento. 
